\author{
Universidade de São Paulo \\ Faculdade de Filosofia, Letras e Ciências Humanas \\ Departamento de Sociologia \\ Programa de Pós-Graduação em Sociologia
}

\title{
A vida privada na mira do sistema: a Internet e a obsolescência da privacidade no capitalismo conexionista
}

Mariana Zanata Thibes

Tese de Doutorado apresentada ao Programa de Pós-Graduação em Sociologia da Faculdade de Filosofia, Letras e Ciências Humanas da Universidade de São Paulo, para obtenção do título de Doutor em Sociologia, sob orientação da Profa.Dra. Maria Helena Oliva Augusto

São Paulo 
Ao Léo. 


\section{Agradecimentos}

Esse doutorado foi realizado em um período muito intenso da minha vida, pleno de acontecimentos muito bons, por um lado, e muito difíceis, por outro. Se as perdas, lutos e mudanças certamente dificultaram a jornada, que já não é normalmente fácil nessa época, as conquistas a tornaram mais doce. Nesse sentido, foi muito importante pra mim ter conhecido meu marido Léo, companheiro da vida, que me ajudou de maneiras que não sou capaz de sintetizar aqui, e por quem tenho um amor imenso e uma gratidão eterna. Devo grande parte desse trabalho a ele, às suas várias leituras e sugestões fundamentais, às nossas inúmeras conversas e dicussões.

Agradeço também e sobretudo à minha orientadora, Maria Helena Oliva Augusto, que me acompanha desde os tempos de iniciação científica, há mais de dez anos, e a quem sou imensamente grata pelas inúmeras orientações, sugestões, pelo apoio nos bons e maus momentos e também pela liberdade e confiança com as quais me agraciou em todo esse período.

Agradeço aos meus queridos amigos, Bruno Boti Bernardi, Carol Peris, Vivi Prado, Leandro Almeida, Meire Ribeiro, Cinthia Mina, "cumadis" Marina Ayra, Marina Funari e Marina Yagima, aos "cumpadis" Eduardo Fernandes e Fernando Vidal Filho, aos colegas do grupo de estudos sobre o self, a intimidade e a sociabilidade contemporânea, Pedro Mancini, Regina Cariello Moraes, Juliana Oliveira e Maíra Volpe.

Também sou grata à família, principalmente ao meu pai, e minha mãe, cujo apoio foi sempre tão forte e fundamental que, mesmo a despeito de sua partida, ainda sinto comigo. 
Finalmente, agradeço aos professores Paulo Menezes e Marcos Alvarez, que fizeram parte da minha banca de qualificação, aos funcionários do departamento de sociologia e ao Conselho Nacional de Desenvolvimento Científico e Tecnológico (CNPq) pelo financiamento. 


\section{Resumo}

Tornou-se comum, no presente, a percepção de que a privacidade está sob ameaça. As novas tecnologias da informação, por seu potencial inédito de coleta e disseminação de dados pessoais, parecem ter se tornado um grande obstáculo à manutenção do resguardo da vida privada, cuja violação não se faz sem prejuízos ao indivíduo e sem perturbações para a vida social.

Entretanto, nota-se também que a exibição voluntária da vida privada não presenciou nenhum tipo de recuo diante dessas ameaças, ao contrário, apenas expandiu-se nos canais que a Internet oferece para ela se realizar. Para entender devidamente a natureza dessa contradição, procuramos mostrar como, em cada fase, ou "espírito do capitalismo", a relação entre vida privada e sistema irá criar uma estrutura própria para a manifestação da privacidade. Ao fazer isso, percebemos que o papel que a vida privada desempenha no atual capitalismo conexionista é fundamental para explicar os condicionantes que levam à exposição de informações pessoais na rede, mesmo a despeito de todas as implicações individuais e sociais que a obsolescência da privacidade possa trazer, e também para compreender de que modo a perda da privacidade pode gerar, além de conflitos e ameaças, renda.

Palavras-chave: Privacidade; Internet; Vida Privada; Capitalismo; Novas Tecnologias 


\begin{abstract}
It has become usual to say that, currently, privacy is under threat. The unprecedented potential for collection and dissemination of personal data brought by the new information technologies seems to have become a major obstacle to the maintenance of private life protection. Its violation does not occur, however, without consequences for individuals and society.

In spite of that we note that the voluntary display of personal life has not suffered any fallback in face of those threats; on the contrary, it seems to be growing on the channels offered by the Internet for that purpose. To properly understand the nature of this conflict, we try to show how, in each stage of capitalism, the relation between private life and the system engenders a particular structure that will give privacy its specific features in each period. By doing so, we realize that the role private life plays in network capitalism is essential to explain the reasons that lead to exposure of private life in spite of all the individual and social implications that the decline of privacy can cause and also to understand how the loss of privacy can generate conflicts and, at the same time, wealth.
\end{abstract}

Key-words: Privacy; Internet; Private Life; Capitalism; New Technologies 


\section{Sumário}

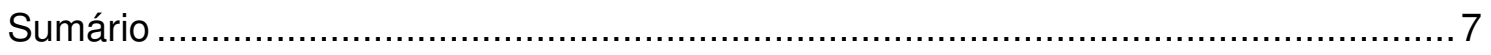

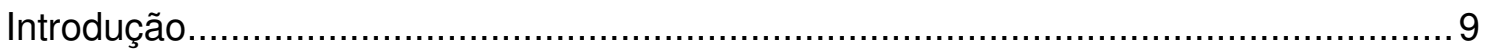

Capítulo 1 - Os Conflitos relativos à privacidade e à Internet...................................... 15

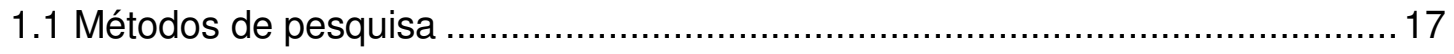

1.2 A Internet no Brasil e em São Paulo e seus conflitos...................................... 18

1.3 Análise geral do material de campo: processos sobre privacidade e Internet no

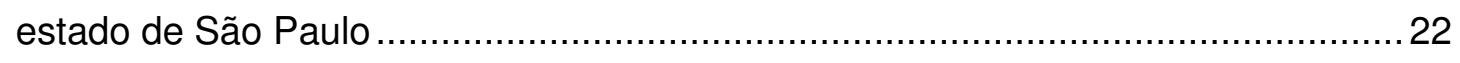

1.3.1 Difamação e danos morais - o embate entre liberdade de expressão e violação de privacidade.....................................................................................24

1.3.2 Requisições de informações de devedor e penhora online........................46 46

1.3.3 Operações bancárias ilícitas via Internet ...........................................50

1.3.4 Apagamento de registro na Internet ................................................54

1.3.5 Operações de marketing, venda e utilização indevida de dados de

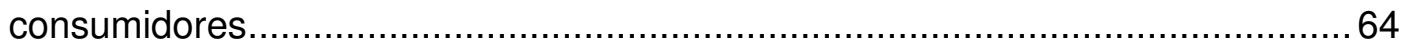

1.3.6 Apropriação indevida de imagem, direitos autorais e propriedade intelectual 69

Capítulo 2 - A privacidade: da invenção burguesa ao presente................................ 86

2.1 As origens: de um privilégio social da burguesia a um direito de todos ..............86

2.2 A privacidade no segundo espírito do capitalismo: da santidade do lar ao

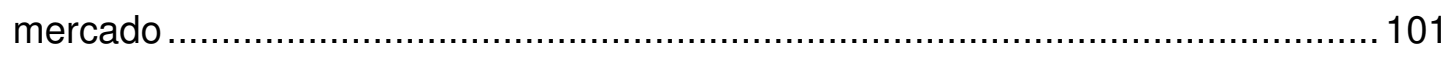

2.3 Espaços de transição e fronteiras em movimento: aproximações entre o público

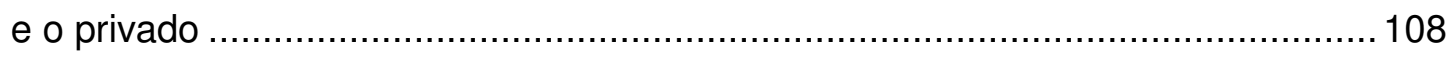

2.4 A vida privada no capitalismo conexionista ............................................ 111

Capítulo 3 - A exposição de si online: reconhecimento, gozo, busca de autenticidade e adequação aos valores do capitalismo conexionista............................................... 122

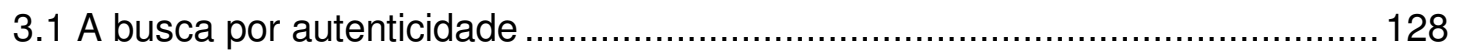

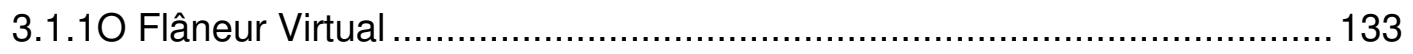


3.1.2 Autenticidade e autenticação

3.1.3 A busca por autenticidade e o narcisismo

3.2 Em busca de reconhecimento

3.3 A exposição online de si online como adaptação aos valores do "capitalismo "conexionista.....

Capítulo 4: A economia das novas tecnologias da informação: transformações econômicas, técnicas e no mundo do trabalho

4.1 A renda do conhecimento. 164

4.2 O setor econômico da informação e sua geração de riqueza 167

4.3 O trabalho nas empresas de tecnologia do Vale do Silício 171

4.4 A apropriação do conhecimento como meio de produção: o trabalho material e imaterial 176

4.5 A apropriação da informação pessoal pelo capital... 189

Conclusão. 194 


\section{Introdução}

Parece ter se tornado senso comum a ideia de que a privacidade está em risco. O desenvolvimento das tecnologias da informação e a alçada da Internet ao cotidiano das pessoas criaram novas ferramentas de captura, armazenamento e disseminação de informações que fizeram estremecer as bases sobre as quais a privacidade se estabelecia. Há alguns anos, quando comecei a estudar o tema, as novas tecnologias da informação ainda não eram largamente disponíveis no Brasil como hoje; logo, essa ideia não despertava tanto a atenção. No espaço de poucos anos, pôde-se verificar a transformação dos discursos relativos à privacidade, de uma ideia fora de pauta, a uma forma cujo conteúdo parece estar se esvaindo. Esse processo não deixa de ser inquietante e já fez com que muitos estudiosos tenham se dedicado a entendêlo.

Após anos acompanhando esse debate, tanto no Brasil, como no exterior, fiquei convencida de que não seria possível explicar o desvanecimento da privacidade sem passar pelas transformações maiores no próprio sistema capitalista. Essas transformações, em parte relacionadas ao desenvolvimento de um novo tipo de tecnologia, e também por um novo tipo de relação entre o sistema e a vida pessoal, são fundamentais para compreender o que de fato ocorreu com a privacidade nos últimos anos.

Em minha dissertação de mestrado, defendida no ano de 2009, estudei a rede social "orkut", da empresa Google, e as vicissitudes que, na época, o novo tipo de sociabilidade nas redes sociais traziam para os que se preocupavam com as mudanças engendradas nas esferas pública e privada. 
Em linhas gerais, o estudo permitiu observar que, embora a exposição da vida privada nos meios públicos já fosse um fenômeno de certa monta há algumas décadas, pelo menos desde os anos 80 , o surgimento da Internet e da sociabilidade virtual fez com que ele adquirisse outra magnitude. Em nenhum outro momento houve um meio que permitisse tamanha inserção, acúmulo e troca de informações em escala global, o que criou novos dilemas para a questão da intimidade e da privacidade.

Como preservar essa esfera de existência a despeito da exposição massiva a que as pessoas se encontram sujeitas após o surgimento das tecnologias da informação e da Internet? Alguns estudiosos chegaram a afirmar o fim de sua possibilidade e o surgimento de uma nova era de exposição total dos indivíduos, um novo Panóptico, com a diferença de que a vigilância agora seria exercida por olhos eletrônicos que dispensariam a presença física do vigilante, ou a concretização da distopia de George Orwell. Essa forma de "vigilância sofisticada" tornou-se tema de muitos estudos que, inclusive, possibilitaram a criação de uma nova área temática, denominada "surveillance studies", ou estudos de vigilância. Mas também povoou o imaginário social com histórias de pessoas que tiveram a vida privada e íntima devassada, fornecendo vasto material para filmes, seriados, novelas e livros ${ }^{1}$. Tornaram-se comuns histórias sobre violações de contas bancárias, emails e perfis de redes sociais por hackers, casos de apropriação e compartilhamento

\footnotetext{
${ }^{1}$ Alguns exemplos de filmes são: The Truman Show (Peter Weir's), Minority Report (Steven Spielberg); Enemy of the State (Tony Scott), The End of Violence (Wim Wenders), Lost Highway (David Lynch), Panic Room (David Fincher), Peeping Tom (Michael Powell) e, na televisão, o seriado Person of Interest, exibido pelo canal Warner, entre outros. Cf. KAMMERER, Dietmar. Video Surveillance in Hollywood Movies. Surveillance \& Society (CCTV Special), 2(2/3): 464-473.
} 
ilegais de imagens, músicas, livros e outros meios protegidos por direitos autorais, bem como incidentes de difamação pela Internet.

Os casos de vigilância parecem ter atingido um ponto crítico a partir das revelações feitas pelo ex-agente da CIA e da NSA, Edward Snowden, acerca da massiva coleta de dados realizada pela Agência de Segurança Nacional norte-americana. Embora a vigilância não constitua um fenômeno novo e seja uma prática adotada por governos desde os anos 20 , sua extensão e ubiquidade certamente são inéditas. Como alertou o ciberativista Julian Assange, do Wikileaks:

"A vigilância é muito mais evidente agora do que na época em que a vigilância massiva era realizada apenas pelos Americanos, os Britânicos, os Russos e mais alguns outros governos como Suíça e França. Agora a vigilância é feita por todos, por quase todos os estados, devido à comercialização da vigilância de massa. E ela tornou-se totalizante, na medida em que as pessoas colocam todas as suas ideias políticas, comunicações com a família e amigos na Internet. Isto significa não apenas um aumento da vigilância sobre esse tipo de comunicações, mas também que o volume de comunicações aumentou significativamente. E não se trata apenas de um aumento no volume de comunicações, mas nos tipos de comunicação. Todos esse novos tipos de comunicação que antes eram privados, agora estão sendo massivamente interceptados ${ }^{2}$.

O volume inédito de dados proporcionado pela Internet despertou o interesse de governos democráticos que passaram a enxergar os fluxos de comunicação na Internet como uma porta de entrada para o controle, para a gestão populacional e para estratégias geopolíticas. Para isso contam com a ajuda não apenas das novas ferramentas de coleta, mas também, com a cooperação de empresas de tecnologia, que passaram a entregar dados de

\footnotetext{
${ }^{2}$ ASSANGE, 2012, p. 21-2, tradução minha.
} 
usuários de seus serviços. Isso tudo sem falar da própria captura feita pelas mesmas empresas, já que as informações pessoais dos usuários/ consumidores passaram a ser parte fundamental de seus negócios.

Diante de tantas ameaças à privacidade, como explicar que a exposição da intimidade, já ativa há algumas décadas, venha só a crescer nos últimos tempos? A proliferação dos serviços voltados à exibição de si online não nos deixa mentir: todos parecem ter aderido ao hábito de mostrar-se nos domínios virtuais.

Porém, isto não ocorre sem consequências. Quando determinados aspectos que constumavam ser protegidos pelo véu da privacidade passam a vir a lume, os resultados podem ser, muitas vezes, desastrosos. A primeira parte de nossa pesquisa procurou mostrar quais conflitos podem ocorrer a partir da introdução da nova tecnologia no cotidiano e da crescente exibição da vida privada promovida em âmbito virtual. Sua atualidade é, por si só, razão suficiente para despertar nossa atenção: são problemas que não existiam há uma década e cuja existência mostra com clareza os efeitos disruptivos que a nova tecnologia introduziu no cotidiano.

Mas, por que esses conflitos passaram a ocorrer? O que mudou na última década que explique sua incidência? Se é certo que eles remetem a mudanças na noção de privacidade, é preciso situá-las historicamente. Para isso, não há outro caminho a não ser entender como a privacidade se constitui e se transforma ao longo do tempo. Desse modo, na segunda parte da tese procuramos reconstituir o que julgamos ser os principais momentos dessa história. Desde sua origem burguesa no século $\mathrm{XIX}$, ao surgimento da Internet e das questões postas pela vigilância, de que modo 
a vida privada se transformou? O ponto de vista adotado nessa narrativa, e que nos confere um recorte, é o da relação entre a vida privada e os desenvolvimentos do "espírito do capitalismo": seus valores, suas demandas e formas de trabalho. Procuraremos mostrar que a relação entre a vida privada e uma nova tecnologia só adquire pleno sentido quando remetida a essa constelação valorativa maior.

Tendo percorrido esse caminho, chegaremos ao ponto em que a exposição de si em ambientes públicos começa a tomar corpo como um fenômeno social de monta e atinge uma magnitude inédita com a popularização da Internet. Desse modo, na terceira parte da tese, procuramos entender as motivações que estão por trás desse comportamento cuja ubiquidade é cada vez mais marcante. Diante de tantas ameaças à privacidade, é surpreendente que não haja recuo da intensidade da exposição de si, o que nos faz conjecturar sobre a existência de condicionantes bastante poderosos por trás dessa atitude. $\mathrm{O}$ caminho que decidimos adotar é o da imbricação entre tais condicionantes e as demandas do chamado capitalismo conexionista. Procuraremos mostrar como essa é a principal vereda para o entendimento da contradição entre, de um lado, as ameaças à privacidade e o temor de perdê-la, e de outro, o hábito da exposição de si online.

Se a prática de expor aspectos da vida privada nos ambientes virtuais obedece a condicionantes fortes do ponto de vista do indivíduo, relacionados à mudança de status que a vida pessoal sofre no capitalismo contemporâneo, opondo-se, dessa forma, aos antigos quesitos de resguardo, resta entender como a vida pessoal, assim desvelada, é 
apropriada pelo sistema. Nos tempos burgueses, valorizar a vida privada significava preservá-la do turbilhão do espaço público; na fase atual do capitalismo, sua valorização ocorre no próprio espaço público. Mas o que significa essa "valorização"? Qual é exatamente o tipo de valor gerado pela vida privada quando ela é integrada à esfera produtiva? Se o seu valor simbólico é mais evidente, a forma como ela é transformada em dinheiro resta confusa.

A popularização da Internet permitiu o desenvolvimento de um novo setor da economia baseado na informação. Embora todo usuário de rede social saiba que seus dados pessoais movem o negócio das empresas desse setor, não é claro o modo como é possível extrair lucro a partir de algo que não constitui uma mercadoria tradicional. $\mathrm{Na}$ medida em que $\mathrm{o}$ destino da privacidade contemporânea depende claramente dessa relação, parece-nos fundamental discuti-la. 


\section{Capítulo 1 - Os Conflitos relativos à privacidade e à Internet}

A popularização da Internet no Brasil é relativamente recente: se entre as classes sociais mais elevadas ela é comum há mais de uma década, entre as mais baixas ainda pode ser considerada uma aquisição nova ${ }^{3}$. De qualquer modo, ela introduziu mudanças significativas no cotidiano de ambas, em geral, sentidas de modo ambíguo, pois se, por um lado, a Internet ampliou de maneira extraordinária o acesso à informação e às formas de comunicação e sociabilidade, por outro, trouxe consigo novos problemas; entre eles, certamente se destacaram aqueles relativos à privacidade.

Entretanto, a despeito dessa ambiguidade, algo sobre o que os usuários não puderam ter dúvidas foi de seu sentimento de que a vida privada não era mais a mesma. Algo inédito havia se passado e vinha se materializando em forma de problemas, de novas formas de relacionamento e de novas fronteiras entre o público e o privado. Conforme dito na introdução, sob o amplo espectro da privacidade online são abrigados desde os casos de vigilância, como os revelados pelo ex-funcionário da NSA, Edward Snowden, até os conflitos corriqueiros, pequenos, que ocorrem no dia a dia das pessoas, tais como recebimento de publicidade indesejada, coleta indevida de dados por empresas, incidentes de calúnia e difamação, uso indevido de imagens, registros em sistemas que criam rótulos estigmatizantes e etc. Esses casos não dispõem de cobertura igualitária pela mídia, por razões que o leitor sabe de

\footnotetext{
${ }^{3}$ Como veremos adiante (pág.11), dados do Comitê Gestor da Internet no Brasil mostram que o novo contingente que passou a utilizar a Internet nos últimos anos é representado pela chamada "classe C". Seja qual for a denominação utilizada, é importante ressaltar que se trata, como afirma Jessé de Souza, de uma "classe social nova e moderna, produto das transformações recentes do capitalismo mundial, que se situa entre a ralé e as classes média e alta" (2010, p.36).
} 
cor: as práticas comerciais abusivas das empresas, por exemplo, raramente são divulgadas e dificilmente reconhecidas como tais. Desse modo, é raro que se saiba o que é feito com a imensidão de dados coletados sobre as pessoas. É preciso conhecer, portanto, de modo mais preciso e confiável, as ameaças e os conflitos que estão presentes no cotidiano dos brasileiros após a disseminação da Internet no país.

Nesta primeira parte da tese, portanto, examinaremos os conflitos sofridos por usuários de Internet que acreditam ter tido sua privacidade violada e de que forma eles transformaram a experiência dessas pessoas. Parece ter se tornado parte do senso comum que as novas tecnologias da informação puseram fim à privacidade. Mas, quais foram exatamente as ameaças criadas à privacidade a partir da popularização da Internet? Veremos que os conflitos aqui tratados oferecem um retrato consistente de como a nossa privacidade vem sendo ameaçada e perdida, e as consequências desse fato. Se a exibição de si online tornou-se parte de nossas vidas, e por meio dela disputamos o acesso a bens simbólicos e materiais fundamentais, ela também tem um preço, às vezes bem alto, a pagar.

Julgamos que a forma mais acertada de chegar a esse resultado seria ir direto ao nicho dos conflitos, o sistema judiciário. Se é correto que nem todos passam por essa instância, ela não deixa de constituir uma excelente via de acesso às disputas, permitindo observar as ideias em construção e os posicionamentos dos atores em jogo, a saber, julgadores, empresas e cidadãos. Se as queixas sobre violação de privacidade muitas vezes chegam primeiro às empresas, nem sempre encontram resolução nessa instância e, 
muitas vezes, para solucioná-las, a procura pelo sistema judiciário é necessária.

\subsection{Métodos de pesquisa}

A seleção dos conflitos judicializados sobre privacidade online foi limitada ao estado de São Paulo, não apenas por ser o local de residência da pesquisadora, mas por acreditarmos que, a despeito da imensa diversidade cultural de um país como o Brasil, as experiências encontradas nesse estado guardam semelhanças fundamentais com as de outras áreas, tanto do próprio país quanto de outros lugares do mundo, e, nesse sentido, podem constituir uma boa amostra dos tipos de problemas relativos à privacidade que se vivenciam no presente.

Portanto, foram definidos como objeto de pesquisa os acórdãos e jurisprudências disponíveis no site do TJSP (Tribunal de Justiça do Estado de São Paulo), consultados a partir dos termos "privacidade e Internet". Nessa seleção, foram encontrados 612 acórdãos entre os anos de 2000 e 2011, os quais foram lidos e catalogados em banco de dados. Cada acórdão possui, além da sentença do juiz, a descrição do caso que a embasa. Ainda que não seja tão extenso quanto o próprio processo, por não conter o material juntado pelas partes, o acórdão discorre sobre o conflito, apresenta os principais argumentos mobilizados pelas partes e a posição do juiz em relação a eles. Assim, embora não tenha sido possível acessar os processos nos cartórios onde se encontram, em sua versão em papel, os acórdãos forneceram extenso 
e rico material para a pesquisa, contabilizando mais de 2000 páginas para serem examinadas.

Após essa primeira fase da pesquisa de campo, os processos foram agrupados por temas recorrentes e selecionados alguns casos para discussão mais aprofundada. Cada um desses temas será tratado num subcapítulo, com a discussão dos casos referentes a cada um, após uma discussão preliminar sobre a Internet e suas especificidades como dimensão social.

\subsection{A Internet no Brasil e em São Paulo e seus conflitos}

Segundo dados do CGI.br ${ }^{4}$ (Comitê Gestor da Internet no Brasil), em 2012, 46\% dos domicílios brasileiros possuíam um computador, percentual que vem crescendo ao longo dos anos. O maior crescimento foi registrado pela chamada "classe C"”: desde 2008, houve crescimento de $19 \%$ em seu uso de computadores. A penetração da Internet nos domicílios brasileiros passou de 13\%, no ano de 2005, para 31\%, no ano de 2010, e, finalmente, 40\%, em 2012. Já a pesquisa realizada pelo Observatório das Metrópoles, do Instituto Nacional de Ciência e Tecnologia ${ }^{6}$, com base nos dados da PNAD-IBGE (2001-2008), mostra que a porcentagem de domicílios com computador na região metropolitana de São Paulo, em 2001, era de 32,6\% no núcleo e 22,3\% na periferia. No ano de 2009, 57,9\% dos domicílios tinham computadores no

\footnotetext{
${ }^{4}$ CGI.br: Pesquisa sobre o Uso das Tecnologias de Informação e Comunicação - TIC Domicílios 2010.

${ }^{5}$ A classificação utilizada pela pesquisa acerca das classes sociais utiliza os critérios definidos pela Associação Brasileira das Empresas de Pesquisa - ABEP - a partir de um sistema de pontos que leva em consideração a posse de itens, tais como geladeira e TV, o grau de instrução do chefe da família e a renda, e a partir dos pontos obtidos, divide as classes em A, B, C e DE.

6 "Acesso às tecnologias digitais no Brasil Metropolitano". Relatório preliminar, 2011.
} 
núcleo, enquanto na periferia já eram 50,9\%. Desses domicílios com computador, $85,5 \%$ tinham acesso à Internet no núcleo e $78,5 \%$, na periferia.

No entanto, é curioso notar que, a partir de 2008, ano em que a Internet teve seu maior crescimento devido à expansão de sua utilização, principalmente pela classe $C$ durante o governo Lula, verifica-se também um aumento notável no número de conflitos relativos à privacidade. Do total de processos encontrados em 12 anos, quase 30\% são referentes a 2011, último ano considerado pela pesquisa:

Gráfico 1 - Porcentagem (em relação ao total) de processos sobre privacidade online no estado de São Paulo (TJSP) entre os anos de 1999 e 2011.

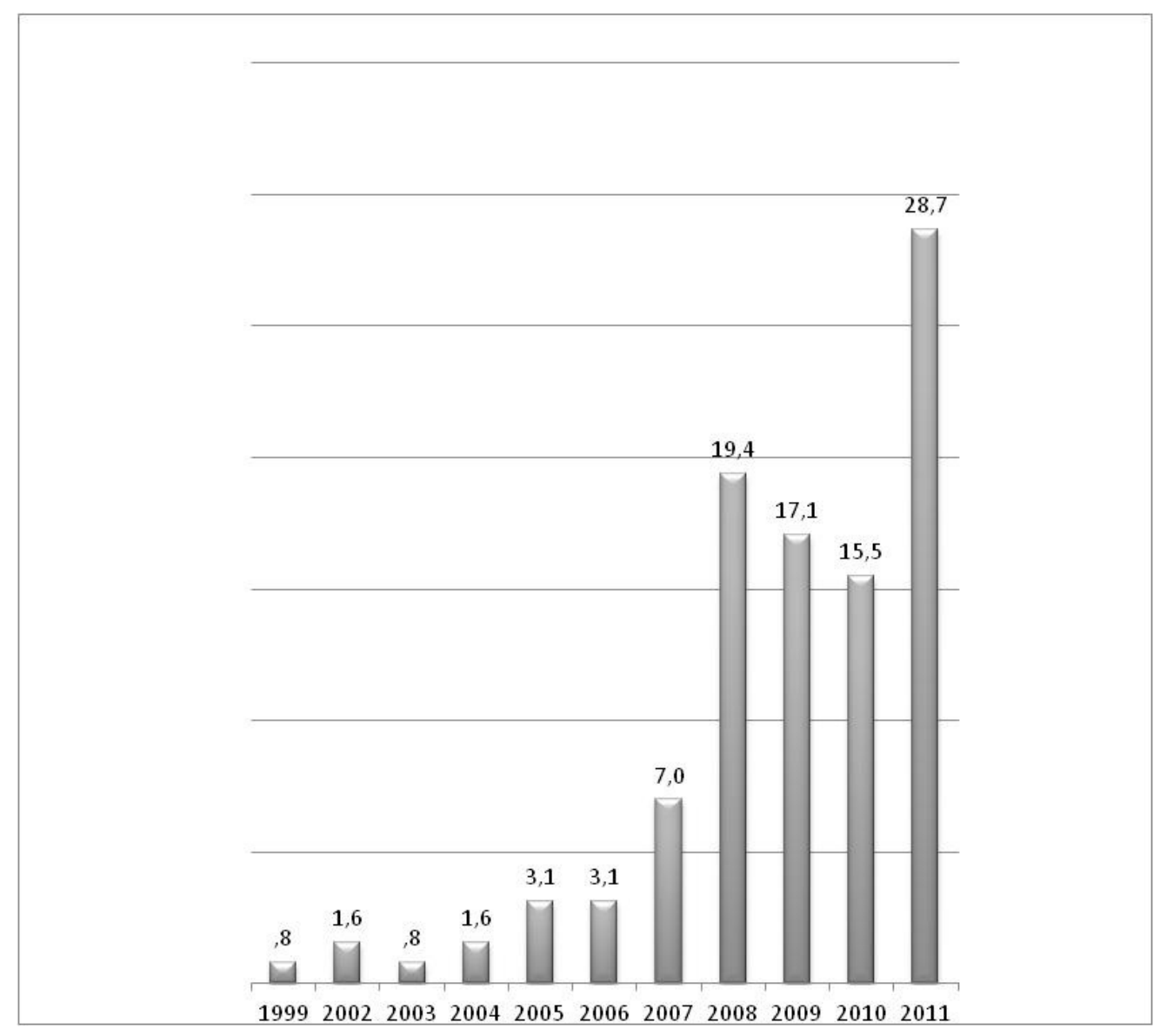


No gráfico é possível notar o crescimento exponencial do número de processos desse tipo ao longo dos anos de 1999 e 2011. Esse é o indício de que os conflitos acerca da privacidade vêm aumentando conforme as pessoas passam a utilizar a Internet com maior frequência. Porém, também mostra que não é possível afirmar que as pessoas estejam aprendendo a evitar esses conflitos, embora a familiaridade com o uso da rede mundial de computadores aumente a cada ano.

Como lembra Sevcenko ${ }^{7}$, em 1896, um dos historiadores pioneiros da tecnologia, o americano William Kennedy Laurie Dickson observou com rigor as derivações mais significativas de uma nova técnica: a sensação de que ela comporta efeitos mágicos, a inferência de que seu advento multiplica os potenciais humanos, a consciência de que ela altera a percepção e a condição do homem comum. Talvez todos esses aspectos sejam válidos para compreender a extensão das transformações que a Internet trouxe à vida humana.

Sabe-se que, além do impacto cognitivo sobre os indivíduos, a Internet, na medida em que oferece uma nova plataforma de sociabilidade, demanda também o aprendizado de novas regras de etiqueta e, claro, novas fronteiras entre público e privado. Rosen conta a história de uma jovem que criou um perfil no Facebook e mudou o status para "casada", quando se casou. Após um tempo, o relacionamento acabou. Além da família e alguns amigos mais próximos, poucos sabiam da notícia. Porém, o ex-marido resolveu tornar 0

\footnotetext{
${ }^{7} 1998$, p.520.
} 
rompimento "oficial" e mudou seu status para "solteiro" na rede social. Todos os amigos mútuos receberam instantaneamente uma mensagem de atualização relatando que o casal estava separado, junto a um coração quebrado. A moça disse que, embora esperasse que conhecidos em breve soubessem da notícia, havia algo desconcertante no fato de que todo mundo tenha sabido da notícia instantaneamente, sobretudo, de forma tão impessoal; ela disse que preferiria ter contado sobre a separação a cada um de seus amigos em uma conversa face a face iniciada por ela, e não por meio do Facebook ${ }^{8}$.

Além dessa história, há outros exemplos da dificuldade de adaptar as regras sociais existentes, ou criar novas, para o ambiente virtual, tais como: 0 que fazer quando um amigo posta comentários inapropriados em seu mural da rede social? Apagar o comentário, sob pena de chatear o amigo? Censurá-lo publicamente? Que opções tenho se alguém posta uma foto embaraçosa de mim no Facebook, ou uma foto que me desagrada? O que acontece se um amigo rompe com o namorado(a)? Você o exclui dos seus contatos? Se alguém o adiciona e você o rejeita, isso é uma rejeição séria? Essas são questões que não nos incomodariam no mundo físico. No virtual elas são geralmente resolvidas com julgamentos instantâneos, mas não desprovidos de ansiedade. A sociabilidade online cria situações para as quais o repertório existente de regras de comportamento não é completamente adequado. São várias as dúvidas sobre como devemos proceder, qual é a etiqueta correta em cada momento e quais os impactos resultantes de cada ação.

Além disso, não há tempo para julgar e aprender: tudo deve acontecer de forma rápida. A Internet é o reino da simultaneidade: enquanto trabalhamos,

\footnotetext{
${ }^{8} 2007$, p.183-4.
} 
escrevemos e-mails, conversamos com amigos nos bate-papos, checamos as atualizações das redes sociais, recebemos mensagens no celular, fazemos pesquisa no Google, lemos o jornal online, os blogs favoritos e mais uma série de outras atividades, todas ao mesmo tempo. O resultado é a dispersão constante da atenção e da concentração, a perda do foco. Não há tempo para demorar-se num único ponto, pois há sempre uma nova informação a ser coletada.

Os deslizes que daí podem surgir são inúmeros. Sem repertório suficiente de ação e sem tempo para pensar, pisamos em ovos. Nada melhor do que isso para estimular o funcionamento das redes de sociabilidade online: "pagar mico" é ruim para quem paga, mas não para quem observa. Quem nunca se deleitou com deslizes de celebridades capturados por lentes indiscretas? Nas redes sociais, isso é dado de bandeja: a todo instante alguém é presa do fluxo incessante do pensamento sem filtros. Enquanto o Facebook pergunta ao usuário no que está pensando, o Twitter, o que está fazendo e o Foursquare, onde ele está, - e as perguntas são respondidas sem que as pessoas parem para pensar - é fornecido o alimento precioso de toda a rede social. As gafes, embora tragam problemas para quem as comete, fazem parte desse banquete.

\subsection{Análise geral do material de campo: processos sobre privacidade e Internet no estado de São Paulo}

A partir do método de seleção escolhido, isto é, a pesquisa no site do Tribunal de Justiça do Estado de São Paulo com os termos "privacidade" e 
"Internet", foram encontrados 612 acórdãos entre os anos de 2000 e 2011. Há apenas 1 acórdão do ano de 1999 e nenhum antes disso. Esse dado confirma que, no Brasil, diferentemente dos Estados Unidos e de outros países asiáticos, (Japão e Coréia de Sul), e europeus (Alemanha, França e Inglaterra), a Internet apenas passou a fazer claramente parte significativa da vida das pessoas a partir do século XXI.

Dos 612 processos encontrados, 365 relacionavam-se, de fato, com conflitos que envolviam privacidade e Internet. Os 247 restantes eram casos de violações de privacidade por outros meios (jornal, revista e telefone, entre outros) ou de conflitos relacionados à Internet, mas não à privacidade. Dos 365 casos que realmente se relacionavam ao objeto de pesquisa, 174 eram desdobramentos do mesmo fato, relativo à publicação dos vencimentos dos servidores municipais pela prefeitura do município de São Paulo. Como diziam respeito ao mesmo conflito, decidimos contabilizar o fato e não os processos, para que não houvesse distorção na análise dos dados e o incluímos na categoria "apagamento de registro na Internet". Os 192 processos que restaram foram agrupados nas seguintes categorias:

1) apagamento de registro na Internet

2) difamação, danos morais, mensagens ofensivas

3) operações de marketing e venda de dados

4) operações bancárias ilícitas via Internet

5) requisição de informações de devedor e penhora online

6) uso indevido de imagem - direitos autorais, propriedade intelectual 
Em relação ao universo total, cada categoria representa a seguinte porcentagem:

Gráfico 2: Porcentagem de processos por categoria em relação ao total (2000-2011) - TJSP

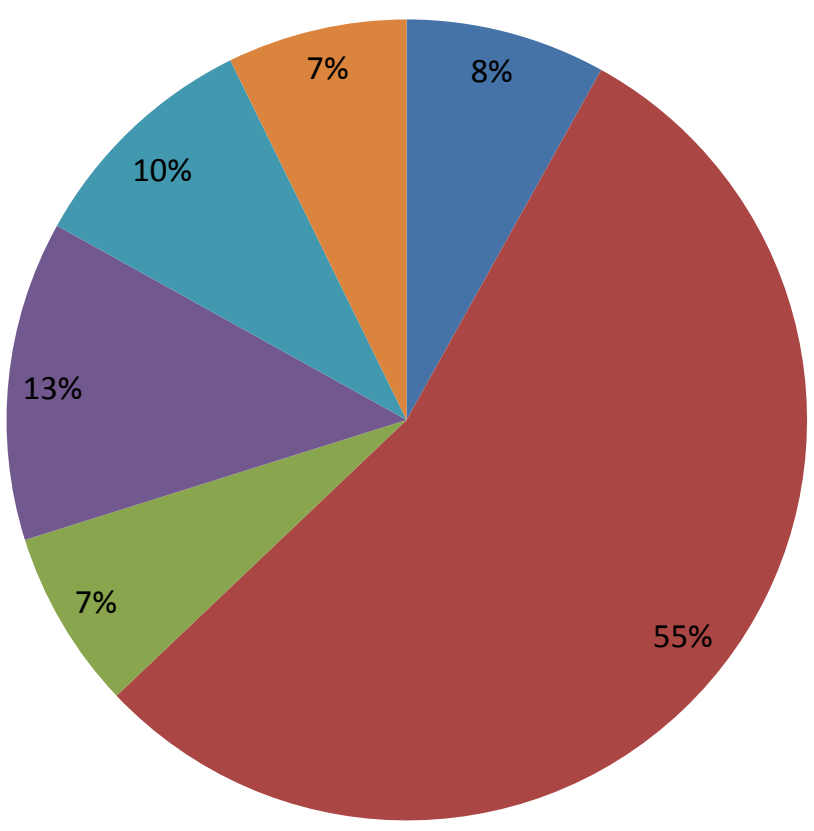

apagamento de registro na internet

- difamação, danos morais, mensagens ofensivas

- operações de marketing, venda e utilização indevida de dados de consumidores

- operações bancárias ilícitas via internet

Requisição de informações de devedor e penhora oline

uso indevido de imagem direitos autorais, propriedade intelectual

\subsubsection{Difamação e danos morais - o embate entre liberdade de expressão} e violação de privacidade

Uma dimensão importante dos conflitos relacionados à Internet é que eles adquirem proporção diversa daqueles ocorridos nas arenas físicas. Um dos motivos para que isso aconteça é que as informações circulam em 
velocidade muito maior e podem se espalhar de modo "viral", além de ficarem indeterminadamente registradas na rede. O modelo viral de expansão significa que cada usuário pode compartilhar com vários outros uma informação, o que permite sua disseminação em progressão geométrica. Como explica Adam L. Penenberg (2009, p.10), “um loop de expansão viral é como juros compostos em uma conta bancária: um usuário torna-se dois, então quatro, oito até 1 milhão e mais". Assim, se recebo um vídeo ou uma foto que considero interessante, posso, em questão de minutos, compartilhá-la com dezenas de amigos, que podem, por sua vez, compartilhá-la novamente com mais dezenas de amigos e assim por diante. Tudo isso em questão de minutos. De acordo com Jim Pugh, CTO da organização Rebuild the Dream ${ }^{9}$, o contágio viral, nesse caso, tem a ver com a quantidade de novas pessoas que cada usuário recruta para uma causa; porém, uma informação tornada viral também rapidamente encontra um ponto de saturação, a partir do qual a disseminação se estabiliza ou decresce. Essa tendência explica o fenômeno das celebridades instantâneas, dos vídeos da moda, os quais rapidamente se tornam "trending topics", mas que precisam ser logo renovados por novos objetos de atenção.

O que interessa reter, para nossos propósitos, é que a circulação de informações na Internet, podendo tornar-se viral, torna difícil, talvez impossível, efetivamente retirar uma informação que tenha entrado no âmbito da rede. Se, por um lado, alguns se aproveitam desse mecanismo para conseguirem seus quinze minutos de fama, outros podem perder, por intermédio dele, um bem social muito valioso: a reputação.

\footnotetext{
${ }^{9}$ Think tank fundado no ano de 2011 que promove "soluções inovadoras para reerguer a economia norte-americana.
} 
No livro The Future of the Reputation (2007), Daniel Solove conta a história de Jessica, uma mulher que trabalhava como assistente de um senador dos Estados Unidos e se envolveu com um dos advogados dele. Ela resolveu criar um blog no qual narrava suas experiências íntimas com o advogado, inclusive as preferências sadomasoquistas do rapaz. Pouco tempo depois, um famoso blog de fofocas descobriu o blog da mulher, identificou de quem se tratava e criou um link para ele. Embora ela tenha descoberto a existência do link e apagado o blog em seguida, não houve tempo de evitar a disseminação do conteúdo, pois milhares de pessoas tiveram tempo de acessá-lo e de compartilhar as informações que ali estavam presentes. A história espalhou-se pela mídia, incluindo o Washington Post, o New York Times e a CNN. A mulher foi demitida; no entanto, a história teve um final curioso. A repercussão dos fatos também Ihe garantiu o status de celebridade. Ela passou a ser entrevistada em vários programas de televisão, posou nua na revista Playboy e ainda escreveu um livro. Para o rapaz, entretanto, o desfecho foi diferente. Ele processou a mulher, afirmando ter sofrido sérios danos morais por conta da divulgação de sua vida íntima. Embora a moça tenha alegado que apenas exercia sua liberdade de expressão ao contar sua vida no blog, não conseguiu evitar o pagamento de indenização por ter violado a privacidade do namorado e causado a ele sérios constrangimentos.

Casos como esse também se tornaram comuns no Brasil, inclusive envolvendo algumas celebridades, como a atriz Carolina Dieckman. Aqui, essas queixas são enquadradas pela lei como difamação. Em alguns países, a common law distingue entre difamação falada (slander) e difamação por outros meios - impresso, imagético, virtual - (libel). Como se nota no gráfico 2, a 
maioria das queixas sobre privacidade online no estado de SP relaciona-se a essa categoria (55\%). Segundo a doutrina de Sérgio Cavalieri Filho ${ }^{10}$, o dano moral é:

“(...) a lesão de interesses não patrimoniais de pessoa física ou jurídica provocada pelo fato lesivo, cuja indenização é um misto de satisfação compensatória e de pena. $\mathrm{E}$ o direito à honra se traduz juridicamente em larga série de expressões compreendidas como princípio da dignidade humana: o nome, a fama, o prestígio, a reputação, a estima, o decoro, a consideração, o respeito, etc., que deve ser também preservada em relação à pessoa jurídica".

Ainda na definição de outro jurista:

"Na realidade, tudo aquilo que molesta gravemente a alma humana, ferindo-lhe gravemente os valores fundamentais inerentes à sua personalidade ou reconhecidos pela sociedade em que está integrado, qualifica-se, em linha de princípio, como dano moral; não há como numerá-los exaustivamente, evidenciando-se na dor, na angústia, no sofrimento, na tristeza pela ausência de um ente querido falecido; no desprestígio, na desconsideração social, no descrédito à reputação, na humilhação pública, no devassamento da privacidade; no desequilíbrio da normalidade psíquica nos traumatismos emocionais, na depressão ou no desgaste psicológico, nas situações de constrangimento moral"11

Dessa forma, sob a denominação de "danos morais" uma série de queixas são abrigadas, entre elas, as de violação de privacidade aqui discutidas. Na realidade, a relação entre os danos morais e a privacidade estabelece-se, no âmbito jurídico, na medida em que a privacidade integra os chamados "direitos de personalidade" e os danos morais são ofensas a esses direitos. No entanto, como explicar o grande número de queixas de danos

\footnotetext{
10 2007, p. 92-3..

${ }^{11}$ CAHALI, 2000. p. 20.
} 
morais relativos à violação de privacidade na Internet? E qual é o papel da Internet na origem desse tipo de problema?

Em seu livro, "The Future of Reputation" (2007), Daniel Solove discute essa questão como um indício de que a Internet esteja tornando as pessoas menos livres. A despeito de toda discussão existente sobre o potencial democrático desse meio, por permitir o livre acesso e a circulação de informações, ele mostra que o fato de vivermos numa era saturada por dados traz implicações maravilhosas e assustadoras. A Internet tornou-se uma biblioteca infinita e fez com que a comunicação e o compartilhamento de informações adquirissem poder e eficiência inéditos. Além disso, tornou-se uma forma cada vez mais utilizada de sociabilidade. A Internet transforma a dinâmica de funcionamento de determinadas práticas sociais, dando novos contornos às experiências de reputação social e status, que envolvem os sentimentos de embaraço, vergonha e orgulho. Essas transformações devemse, principalmente, ao fato de que, nela, o grau de exposição é, sem dúvida, maior, o que dificulta o controle das pessoas sobre a sua reputação e apresentação.

Como Erving Goffman (2005) mostrou acerca das interações face a face, o eu é um assunto cerimonial fundamentalmente motivado pelo desejo de ser bem considerado, já que emocionalmente vulnerável - facilmente atacável, traído, desacreditado, constrangido, e etc. Porém, se todas as interações oferecem riscos - de falha, exposição e rejeição -, elas também carregam a promessa de satisfação se as ameaças puderem ser evitadas. Essa é a dinâmica que rege a ocorrência de interações sociais nos limites físicos de uma arena, mas que também está presente nas interações em âmbito virtual: o 
comportamento apresentado online pelos usuários é reflexo do que eles são ou gostariam que os outros pensassem que são. Isso diz respeito à tentativa de controlar a maneira como aparecem para os amigos, online e offline.

A diferença é que, nas interações face a face, os outros podem utilizar aspectos não governáveis do comportamento expressivo do indivíduo como prova da validade do que é transmitido pelos aspectos governáveis, isto é, podem perceber expressões sobre as quais o indivíduo tem pouco controle, como gestos, olhares, posturas corporais, expressões faciais que constituem informação importante durante a interação. Em suma, todos os elementos que compõem o contexto da interação estão presentes para guiar os participantes.

$\mathrm{Na}$ sociabilidade virtual, esses elementos estão suprimidos, o que certamente dificulta a interpretação do sentido das manifestações no decorrer da comunicação. Muitas situações podem ser utilizadas como exemplo. Dizer palavrões num estádio de futebol, ou no trânsito, é muito diferente de dizê-los em ambiente virtual. Criticar o chefe durante o almoço num restaurante também é muito diferente de fazê-lo numa rede social.

Assim, imaginemos a seguinte situação: duas pessoas sentadas em um bar, ou em um ônibus, ou em qualquer lugar público do mundo físico. Uma delas queixa-se sobre seu trabalho como atendente em um banco e comenta sobre sua tensão ao lidar com clientes mal-humorados e mal-educados e, eventualmente, cita alguns dos nomes de tais clientes, sem o objetivo de identificá-los, mas apenas para facilitar a conversa. Pode ser que além de seu amigo, algumas pessoas ao redor escutem o diálogo, mas dificilmente algum conhecido desses clientes estaria presente nesse momento, ou essa conversa poderia ter alguma implicação negativa para os envolvidos. Dessa forma, o 
resultado desse diálogo não teria provavelmente nenhuma repercussão fora dos limites do espaço em que ocorreu.

No entanto, se a mesma conversa acontecesse em um local virtual, na Internet, o desfecho poderia ser completamente diverso, como mostra um dos processos encontrados. Nele, uma empregada do banco Citybank, responsável pelo atendimento ao cliente do cartão de crédito Tam Platinum, foi processada por difamação e condenada a pagar indenização por danos morais a uma cliente ofendida. A empregada criou uma comunidade na rede social Orkut com o nome de "Tam Pratinho" para que ela e seus colegas pudessem desabafar sobre as tensões enfrentadas no dia a dia do trabalho, o que incluía comentários sobre alguns clientes, com críticas sobre falta de educação, mauhumor, etc. A criadora da comunidade teceu um comentário sobre uma cliente que ligou muitas vezes para o atendimento por conta de problemas com 0 cartão e, com sua insistência, "tirou do sério" alguns atendentes. Algum conhecido da cliente teve acesso por acaso à comunidade, leu o comentário, e conseguiu identificar de quem se tratava, avisando a ofendida que "estavam falando mal dela no Orkut". A partir disso, ela entrou com ação contra a criadora da comunidade, por difamação e danos morais, contra o Citybank, o empregador, e contra o Google, para a exclusão da comunidade. O processo foi ganho em primeira instância e a criadora da comunidade, condenada a pagar indenização por danos morais, bem como o próprio banco; o Google teve de excluir a comunidade do Orkut. A comunidade foi excluída, mas o banco apelou para que seu envolvimento no caso fosse desconsiderado, já que não se julgava responsável pelas atitudes de sua empregada, o que foi acatado 
pelo juiz. Como resultado, apenas a moça empregada do banco foi condenada a pagar indenização por danos morais à cliente ofendida.

É possível imaginar que a rotina de um atendente de telemarketing de banco seja permeada por momentos de tensão e cansaço. Como mostrou Jessé Souza no livro Os Batalhadores Brasileiros, "o telemarketing é uma ocupação cuja constituição é precária"12 e não há um canal satisfatório para que as queixas e demandas sejam ouvidas no próprio ambiente de trabalho; assim, não surpreende que sejam despejadas em uma rede social ou emudecidas. Sobre a rotina de um desses trabalhadores, o autor comenta:

"O trabalho é intenso e geralmente tem-se mais trabalho do que se pode suportar, além da constante cobrança pela redução do tempo de atendimento. (...) Em situações mais complexas, de difícil resolução, a tensão aumenta, e ele geralmente é constrangido a usar o botão 'mudo' para aliviar a tensão. 0 'mudo' é um mecanismo utilizado pelo operador toda vez que a tensão aumenta ao nível de o cliente xingá-lo, e então o 'mudo' serve para o atendente retrucar, mas detalhe: sem que o cliente escute. $O$ mecanismo em jogo é o de criar a falsa sensação de que o cliente e 0 atendente estão em pé de igualdade. Qualquer possibilidade de responder à altura é completamente neutralizada. O conforto produzido pelo 'mudo' é o de criar a sensação de que 0 atendente pode reagir ao ser desrespeitado, nada mais falso e paliativo. A eficácia, então, é a de criar um mecanismo placebo, um pseudoalívio da tensão emocional (...), compensatórios pela enorme tensão no ambiente de trabalho"13.

Embora não seja responsável pelos problemas que os clientes enfrentam, o atendente é a única via de contato do cliente com a empresa e acaba transformando-se em local para despejar o descontentamento, a ponta mais fraca da corda que pode arrebentar. Sua única saída é o uso do botão

\footnotetext{
12 2010, p.62.

${ }^{13}$ Idem, p.65
} 
mudo, um emudecimento em voz alta, única forma de responder à altura sem que o cliente ouça. No entanto, no caso "Tam Pratinho", o cliente ouviu. O uso da rede social nesse caso pareceu funcionar como um "botão mudo", uma forma de poder extravasar a tensão, desabafar, vingar-se do cliente, sem que ele ouvisse. Porém, na Internet as paredes têm ouvidos e essa foi a grande lição da atendente processada.

De acordo com Goffman, todo espaço é limitado por certas barreiras antepostas à percepção. Nesse sentido, há ambientes mais e menos expostos aos olhares dos outros. Ele distingue duas regiões principais em toda atuação: a região de fachada e os bastidores, ou fundo cênico. A região de fachada é aquela na qual a representação do eu é executada ${ }^{14}$ e, posto que ocorre na presença de um público (os outros em geral), nela predomina a formalidade, com as regras de etiqueta, decoro e cortesia, bem como o "esforço para dar a aparência de que sua atividade nessa região mantém e incorpora certos padrões"15. Esse é o âmbito da tensão, o espaço onde os indivíduos devem manter-se alertas. O fundo cênico ou espaço dos bastidores é definido como o espaço no qual aquilo que é suprimido da região de fachada aparece e no qual as atitudes de encenação são anti-naturais, pois não há necessidade de manter a máscara que o prepara para o enfrentamento do espaço público, com seus códigos e regras específicos. Pode ser considerado o âmbito da ação menos preocupada com as aparências, e portanto, onde predomina maior liberdade de expressão, no sentido de menor cuidado com as regras de apresentação. Os bastidores são um espaço fechado, limitado voluntariamente

\footnotetext{
${ }^{14} 1985$, p.102.

15 Idem.
} 
para evitar uma potencial intromissão. É do mesmo modo uma esfera de ensaio da atuação que se fará na fachada, a antessala que serve para preparar a atuação no espaço público. O espaço entre bastidores é o lugar onde as pessoas interagem com confiança, sem travas formais, o âmbito onde reina a familiaridade. No fundo cênico, muito próximo da ideia de esfera privada, o indivíduo pode, se não retirar totalmente a máscara, ao menos afrouxar a tensão que o mantém alerta nas interações em espaço público.

A esfera da Internet, por sua vez, não pode ser definida nem como região de fachada, nem como bastidores. Algumas de suas características exacerbam sua posição de fachada e outras fazem com que pareça ser tão privada quanto os bastidores. A controvérsia é estabelecida quando, embora em espaço mais exposto do que os tradicionais, os indivíduos sentem como se estivessem em uma arena privada, isto é, em um espaço no qual pudessem manifestar o pensamento sem muitas reservas e afrouxar a censura que as mantêm alertas nos espaços públicos. Contradição que se torna ainda mais exacerbada quando, apesar de todas as ameaças à privacidade, conhecidas e trazidas pela Internet, a exposição não se apresenta como inadvertida, mas sim, deliberada.

A separação, antes clara, entre bastidores e fachada, tornava evidente que o que era dito em casa não se dizia na rua, tampouco a forma de se portar na igreja não era a mesma que no trabalho, e ambas muito diferentes da forma de se portar dentro de casa. Quando essas regiões e comportamentos se confundem, como em ambiente virtual, em outras palavras, quando os códigos dos bastidores - onde se pode falar com grande liberdade o que quiser - são utilizados na esfera pública, diversos tipos de perturbação para a sociabilidade 
são causados. Se o direito reconhece neles uma natureza comum e os abriga na classe das ofensas de difamação, ou qualquer outro rótulo legal, aqui podemos considerá-los em sua natureza específica de violações de códigos sociais.

Para ilustrar como essas violações acontecem, podemos tomar como exemplo um jogo de futebol. Quando se assiste a uma partida dentro de um estádio, é comum e aceitável praticar a chamada "catimba". O mesmo, contudo, não ocorre quando reproduzido em ambiente virtual, como mostra a história de um dos diretores da empresa Locaweb, Alex Gilkas. O rapaz, torcedor do Corinthians, assistia a um jogo de seu time contra o São Paulo pela televisão. Feliz com o gol que seu time havia feito, ele praticou uma espécie de "catimba virtual" e postou no Twitter uma ofensa ao São Paulo, time patrocinado pela Locaweb. Ao se dar conta do que sua atitude poderia ocasionar, tentou apagar o comentário. Porém, já era tarde; as mensagens haviam sido replicadas por torcedores enfurecidos com o fato de o diretor de um patrocinador estar torcendo abertamente para o adversário, e de forma considerada desrespeitosa por muitos. Protestos percorreram rapidamente as redes sociais e foi sugerido até um boicote à Locaweb, que se viu obrigada a emitir um comunicado oficial pedindo desculpas pelas atitudes do diretor, que deu a muitas pessoas a impressão de que a sua opinião pessoal era a opinião institucional da empresa. O funcionário, que trabalhava há mais de oito anos na empresa, foi demitido. Oito meses após o incidente, atendendo a pedidos de clientes pela sua volta, a empresa decidiu recontratá-lo. No entanto, certamente o descuido não deixou de ser associado à sua imagem. 
Um outro aspecto fundamental das interações tradicionais que é perturbado em ambiente virtual diz respeito ao controle sobre a impressão que se quer causar nos outros por meio da apresentação do eu. Esse tipo de controle sobre a impressão é sobremaneira dificultado com a ampliação da platéia de observadores nos ambientes virtuais. Se nos ambientes públicos tradicionais, é possível guiar com maior segurança a interação pelos aspectos visíveis do cenário e dos observadores presentes, na interação online nunca se sabe ao certo por quem se está sendo notado. A funcionária do caso Tam Pratinho, por exemplo, certamente não imaginou que entre os observadores de seus comentários na rede social estaria algum conhecido da cliente ofendida. Tampouco o diretor da Locaweb, ao catimbar o São Paulo pelo Twitter, imaginou que estaria sendo visto por centenas de torcedores indignados com sua atitude. A impressão negativa desse modo criada é muito difícil de ser desfeita quando envolve os domínios virtuais. Se nas interações tradicionais podemos contar com o esquecimento dos outros sobre um fato desagradável a nosso respeito, a Internet, com seus registros infindáveis de informação e mecanismos de busca muito eficientes para encontrá-la, torna essa esperança vã. Assim, quando se diz numa rede social algo de que se arrependa, não basta voltar atrás e tentar apagar o que foi dito, pois a informação já pode ter circulado para uma audiência inesperada e ter sido indefinidamente replicada.

Para evitar esse tipo de problema, alguns poderiam pensar, bastaria não participar das redes sociais,. Entretanto, existem casos em que, mesmo não participando dessas redes, pessoas se deparam com informações suas inseridas ali por terceiros. A esse respeito, há o caso de um advogado que se dirigia ao fórum João Mendes, num dia comum de trabalho, e foi surpreendido 
por um homem com o corpo todo salpicado de talco ou farinha, que gritava com ele e tentava abraçá-lo, o que causou grande constrangimento ao rapaz. A cena foi filmada e inserida no Youtube por um desconhecido. O advogado entrou com ação contra a empresa Google para que o vídeo fosse retirado do ar e que the fosse paga indenização por danos morais, já que, segundo ele, a veiculação do vídeo trouxera constrangimento e ridicularização no seu meio profissional e pessoal. O Google alegou que não era responsável pelos conteúdos postados no Youtube, na medida em que, em seus termos e políticas de uso, o usuário assume integral responsabilidade por suas inserções. O juiz não acatou a defesa da empresa e considerou-a responsável pelo conteúdo inserido em seus domínios, condenando-a a remover o vídeo e a pagar indenização por danos morais ao advogado no valor de vinte salários mínimos. Porém, ainda que o conteúdo tenha sido excluído e a indenização paga, não há garantias de que o vídeo tenha desaparecido para sempre ou que a reputação do rapaz possa ser recuperada.

Muito semelhante é o caso que envolveu moradores de um condomínio de luxo em Cotia. Um deles criou uma comunidade no Orkut para tratar de assuntos referentes ao condomínio e postou nela fotos de uma moradora vestida de bruxa para uma festa de Halloween. A mulher ofendeu-se e entrou com ação judicial, pois as fotos foram publicadas "sem o seu consentimento" e "com o interesse escuso de difamação e nítido caráter de denegrir sua imagem, taxando-a de pessoa má e perversa". Segundo a mulher, essa foto poderia comprometer sua reputação e ocasionar danos futuros, como perda de emprego e até roubo e sequestro, por conta da identificação do lugar onde mora. O juiz, por sua vez, não entendeu que houvesse violação à privacidade 
na postagem daquela foto, apenas "a divulgação de registros do cotidiano do condomínio em que residem ambos”. Contudo, é possível especular que as queixas de ofensa e de violação de privacidade deveram-se, nesse caso, ao fato de que a foto de bruxa, retirada do contexto em que ocorreu, a festa de Halloween, poderiam adquirir outros sentidos, além do mero registro da sociabilidade no condomínio. A mulher não esperava que seu vizinho pudesse divulgar, sem seu consentimento, uma foto que, retirada do seu contexto original, poderia denegrir sua imagem. Além disso, no momento em que a tal foto foi inserida na rede social, ela deixou de estar disponível apenas para os participantes da festa e moradores do condomínio, fazendo com que o controle da fotografada sobre sua imagem fosse anulado. Em outras palavras, ela não poderia mais escolher para quem desejaria mostrá-la.

Pode-se considerar que o controle sobre a informação pessoal não somente faz parte do que se entende como direito de privacidade, mas é um elemento fundamental para o equilíbrio das interações sociais. Quando isto é perdido, ou dificultado por conta de um novo tipo de circulação e apreensão de informações, certamente há um saldo, que aparece em forma de conflitos sociais, judicializados ou não. Segundo Helen Nissenbaum (2011), a circulação de informações pessoais obedece a normas relativas ao contexto em que a interação ocorre. Os parâmetros-chave das normas dessa circulação são os atores (sujeito, emissor, recipiente), os atributos (tipos de informação) e princípios de transmissão (restrições que o fluxo de informação encontra). Geralmente, quando a circulação de informações adere às regras do contexto em que se dá, tudo corre bem. Ao contrário, violações a essas regras geram conflitos. Como exemplo, a autora menciona os serviços de saúde. Nesse 
contexto, os pacientes esperam que os médicos mantenham a confidencialidade das informações, com exceção do compartilhamento com especialistas, caso seja necessário. As expectativas do paciente seriam desconsideradas e haveria conflito se soubessem que seu médico vendeu, para uma empresa de marketing, informações a seu respeito. Nesse caso, é possíver dizer que foram violadas as normas de circulação de informação do contexto de cuidados de saúde.

As novas tecnologias da informação e, principalmente, a Internet perturbaram radicalmente não apenas os códigos relativos às esferas pública e privada, mas também as regras de circulação e de apreensão de informações pessoais. Há grande confusão acerca do que se pode ou não publicar, do que está ou não sendo visto ou monitorado, do que irá ser feito com as informações coletadas, ou sobre os sentidos que adquirem fora dos contextos que thes deram origem.

Em minha passagem pelo escritório da empresa Google, notei que grande parte das requisições judiciais que a empresa recebia dizia respeito a disputas acerca dos sentidos de um conteúdo publicado nos produtos da empresa, isto é, se se tratava de exercício da liberdade de expressão ou difamação. Se um empregado utiliza uma rede social para fazer críticas à empresa em que trabalha, isso constitui dano moral para a empresa ou é apenas o exercício da liberdade de expressão do funcionário? Na verdade, ainda que determinadas expressões possam ser consideradas como fazendo parte do exercício da liberdade de expressão, e não punidas judicialmente, os danos concretos que causam à reputação ou à imagem pessoal de alguém acabam por exercer outro tipo de punição, que não atravessa o âmbito jurídico, 
como perda de emprego, de credibilidade, de relações e etc. Nesses casos, o direito pouco pode fazer para recuperar o que foi perdido e o julgamento público parece imperar sobre o próprio parecer jurídico.

A esse respeito, há uma série de exemplos, entre eles o caso Mainardi x Nassif, no qual Diogo Mainardi, então colunista da revista Veja, processou, por difamação e danos morais, outro colunista, Luis Nassif, que possui blog no site do provedor IG do Brasil. O motivo do processo foi uma série de textos escritos por Nassif, em fevereiro de 2012, em que criticava o "quarteto" formado pelos jornalistas Diogo Mainairdi, Lauro Jardim, Mário Sabino e Eurípedes Alcântara. A relação entre os quatro serviria, segundo Nassif, para favorecer um esquema criado pela revista Veja com o banqueiro Daniel Dantas, preso pela Polícia Federal na Operação Satiagraha. Nassif teceu uma série de críticas à entrevista feita por Mainardi com Daniel Dantas, afirmando que se tratava de "armação para que o entrevistado pudesse dizer aquilo que the interessava".

Os trechos considerados difamatórios citados na sentença foram os seguintes: "Não sei a razão objetiva desse assédio. Poderia ser o fato de Mainardi ter mostrado ser 'colunista sela' - nome que se dá ao colunista pouco informado que se deixa 'cavalgar' pela fonte, tornando-se mero repassador de recados, em troca da repercussão que as notas proporcionam. "O fato é que os lobistas perceberam em Mainardi um colunista em disponibilidade. Além disso, seu próprio papel de 'para-jornalista' na revista (...) rompia com os limites do jornalismo e abria campo amplo para divulgar qualquer informação que the fosse entregue, mesmo sem a necessidade sequer de um simulacro de apuração jornalística. E Mainardi se revelaria com falta de escrúpulos suficiente para cometer qualquer assassinato de reputação que the fosse encomendado." 
"Como Mainardi jamais havia escrito sobre tema intrincado como esse, era óbvio que estava sendo 'cavalgado' por Dantas, que lhe entregara o dossiê pronto. Aliás, como em praticamente todas as colunas que escreve sobre disputas empresariais."

Segundo Mainardi, o conteúdo dessas matérias extrapolou a crítica profissional, alargando-a para aspectos de cunho pessoal, jocosos e ofensivos. Luis Nassif defendeu-se ressaltando a função social da investigação jornalística, liberdade de pensamento e acesso à informação, consagradas pela Constituição Federal. Negou que tenha havido crítica pessoal e afirmou ter havido crítica objetiva de cunho técnico. "Acrescenta que as críticas eram direcionadas ao estilo da revista Veja para a qual o autor escreve. Acredita na inexistência de prova acerca do abalo moral, anotando que as críticas teriam sido dirigidas às matérias e não ao jornalista”.

Segundo o juiz, não apenas Nassif, mas também o site IG, seria culpado pelas ofensas. O provedor que hospeda o blog de Nassif foi considerado responsável não apenas pela hospedagem, mas também por divulgar os textos "ofensivos". A ofensa ocorreu na medida em que "o jornalista requerido ao dirigir críticas à entrevista feita pelo autor e ao conteúdo de seus artigos, levantou suspeita a respeito da integridade moral do autor, sua isenção como jornalista e ainda avançou para críticas à sua postura em relação à sua vida pessoal”.

Nassif teria, portanto, excedido o direito de liberdade de expressão e avançado os limites dos direitos de privacidade de Mainardi. A condenação foi o pagamento de indenização no valor de $R \$ 30.000,00$ mais as custas do 
processo. O juiz apenas negou a obrigação de Nassif publicar a sentença em seu blog, como queria Mainardi.

Finalmente, em maio de 2012, o processo teve outro desfecho: Luís Nassif decidiu apelar e conseguiu que a Editora Abril concedesse direito de resposta a ele na revista Veja. O julgador entendeu dessa vez que os comentários feitos por Nassif a Mainardi estavam dentro dos princípios da liberdade de expressão. A sentença, publicada no blog de Nassif, obrigaria a revista ao pagamento de multa de $\mathrm{R} \$ 500.000,00$, em caso de descumprimento. Mas isso, segundo Nassif, após uma "dura luta" e a desistência de seu anterior escritório de advocacia de defendê-lo no processo, que parecia perdido.

Em outro caso parecido, o ex-governador do estado de São Paulo, Luis Antônio Fleury Filho, também processou a revista Veja, por difamação e danos morais. O motivo da queixa foi uma matéria que divulgou "boatos acerca da propriedade ilícita de imóveis pelo autor", na cidade de Botucatu, e sobre a existência de "laranjas" que teriam enriquecido após trabalharem para Fleury em sua campanha eleitoral. Do mesmo modo, o juiz também considerou que houve abuso do direito à liberdade de expressão e que a revista não poderia apoiar-se em "boatos" para publicar matéria que insinuaria atividades ilícitas do político. A revista foi condenada a pagar indenização por danos morais.

No caso de um debate tradicional, os elementos que cercam o que é dito, tal como o tom de voz, o contexto da fala, as expressões faciais e corporais são fundamentais para guiar a interação e facilitar a interpretação dos participantes. Como observa Goffman, 
Uma interação pode ser propositadamente estabelecida como oportunidade e lugar para enunciar diferenças de opinião, mas em tais casos os participantes devem ter o cuidado de concordar em não discordar quanto ao tom de voz conveniente, vocabulário e grau de seriedade com que todo argumento deve ser exposto, e quanto ao mútuo respeito que os participantes discordantes devem cuidadosamente continuar a expressar uns para com os outros. Esta definição da situação dos debatedores, ou definição acadêmica, pode também ser invocada súbita e prudentemente como meio de traduzir um sério conflito de opiniões em outro que possa ser tratado dentro de uma estrutura aceitável por todos os presentes ${ }^{16}$.

Em um debate online, além da ausência dos componentes da cena física que orientam a interação, há uma audiência indefinida a presenciar o debate. Se na arena física sabe-se quem são os ouvintes, quais são os códigos de cada ambiente (trabalho, casa, escola, rua) e o que pode ser dito em cada um deles, sem esses elementos para guiar a apresentação do eu, deslizes são frequentes, e muitas vezes, tornam-se processos judiciais. Desse modo, fica claro que a liberdade de expressão na Internet não é equivalente à liberdade que se tem na esfera privada, tampouco a mesma que se tem no espaço público tradicional.

Além disso, se nas arenas físicas o que é dito não costuma ficar registrado e pode ser mais facilmente esquecido, a Internet é uma base de dados com longa memória. O fato de haver muita informação disponível em um recipiente com tamanha capacidade para reter e disseminar dados - sendo que parte dessa informação pode ser falsa, embaraçosa, ou apenas privada - pode criar sérios problemas para a reputação dos indivíduos. Se lembrarmos que a motivação essencial de toda interação é o desejo de ser bem considerado

\footnotetext{
${ }^{16} 1985$, p.19.
} 
(Goffman, 2003), ter má reputação pode causar grandes prejuízos para a vida social de alguém, tanto materiais, quanto subjetivos.

No caso da Sala Vip Pizza Bar, os prejuízos foram bastante objetivos. Um cliente avistou uma barata em cima de uma das mesas do restaurante, gravou a cena em seu celular e postou o vídeo no Youtube, de forma anônima. O restaurante processou o site por hospedar o vídeo, exigiu sua exclusão e pediu indenização por danos morais. O juiz entendeu que o Youtube não poderia ser responsabilizado pelo conteúdo ali inserido, mas concedeu a exclusão do vídeo e o fornecimento de dados de identificação do usuário que o postou. No entanto, o caminho que o restaurante teria de percorrer para encontrar o usuário ainda seria longo. O máximo que o Google (detentor do Youtube) pode fornecer são os logs de acesso e dados cadastrais do usuário. Essa empresa não exige o fornecimento de documentos ou nomes completos para a utilização de seus serviços. Com isso, a empresa teria de abrir outro processo, para exigir do provedor da conexão de Internet do usuário os demais dados de identificação, como RG, CPF e nome completo. O restaurante teria, então, de entrar com uma terceira ação contra o usuário - agora identificado para exigir indenização por danos morais. Ainda assim, pouco restaria a ser feito para recuperar a reputação do restaurante; afinal, os rumores de ser um lugar sujo certamente se espalharam com mais velocidade do que o desfecho do processo.

Do mesmo modo, no caso da atriz Carolina Dieckmann, que recentemente teve fotos nuas roubadas de seu computador e divulgadas na Internet, a única compensação que pôde ser conquistada foi a punição dos culpados pelo roubo e divulgação das imagens. Essa também é a lição deixada 
por um caso anterior, da apresentadora Daniella Cicarelli, que foi filmada fazendo sexo com o namorado numa praia espanhola e cujo vídeo, divulgado no Youtube, mobilizou uma série de ações do casal para que a disseminação fosse contida. Em vão. Sabe-se que depois disso, a carreira da apresentadora não teve mais sucesso. As fotos de Carolina Dieckmann também não serão resgatadas, tampouco sua intimidade.

A privacidade possui papel fundamental no controle sobre a apresentação do eu, que vem sendo claramente dificultado com a popularização da Internet. Talvez seja difícil para essas atrizes, e para muitas outras pessoas que tiveram a privacidade violada de forma semelhante, serem lembradas, a partir de agora, de forma diferente à do registro que a Internet criou sobre elas. Após o surgimento da Internet, foi possível que muitas pessoas realizassem o desejo de aparecer, de afirmar sua imagem, de fazer muitos amigos e se tornarem "relevantes", ou celebridades instantâneas. Ao mesmo tempo, também se multiplicaram os casos daquelas que passaram a ser lembradas por seus maus momentos, por coisas que desejariam manter escondidas, ou por situações que, retiradas de seu contexto, se tornaram difamatórias. Entretanto, é necessário lembrar que o critério de relevância, motor do logaritmo valioso das buscas do Google, também opera nesses casos. Assim que o público perder o interesse sobre o assunto e ele deixar de ser "relevante", o buscador do Google não terá razões para encontrá-lo. A relevância, nesse caso, significa a popularidade que determinada informação alcança na rede e é medida pelo número de acessos ou cliques que ela obtém. Se o critério de julgamento de relevância de um conteúdo é a popularidade, logo, não está em jogo se a informação é boa, ruim, ofensiva, falsa ou 
redundante. Desse modo, fica claro que, quando a intimidade é posta online, problemas podem ser criados para quem a expôs, mas não para quem a transformou em dinheiro.

Todos os casos analisados até então mostram que sob o rótulo de difamação são englobados não apenas incidentes em que houve calúnia, ou ofensas verbais, mas perda de emprego (como no caso Locaweb e Tam Pratinho), de reputação, e sentimentos de vergonha e embaraço. Diante disso, seria razoável pensar que um código próprio de expressão na Internet fosse permeado por moderação e cautela. No entanto, é o contrário o que se observa. A todo instante alguém é presa do pensamento sem filtros que parece ser de praxe nos ambientes virtuais, principalmente nas redes sociais. Se é possível pensar que a Internet, com suas regras próprias de circulação de informações e ausência dos parâmetros que guiam a interação face a face, cria um ambiente no qual desentendimentos e problemas como os relatados nesse capítulo são frequentes, por que a atitude que os gera, isto é, o da falta de cuidado com o que é apresentado, continua existindo? Em outras palavras, porque as pessoas permanecem se comportando como se estivessem em sua própria casa no ambiente que não poderia ser mais distante, no que diz respeito à proteção, de uma casa? Essa questão nos perseguirá ao longo da tese, mas antes de respondê-la, veremos quais são, além da difamação, os demais resultados da perda da privacidade online. 


\subsubsection{Requisições de informações de devedor e penhora online}

Dez por cento dos processos encontrados sobre privacidade e Internet dizem respeito à chamada "penhora online", acionada pelo credor, para acessar as finanças de um devedor diretamente na instituição bancária, podendo então pleitear o recebimento de dinheiro em vez de bens, como pagamento de uma dívida. Como exemplo, há o caso de uma clínica em Ribeirão Preto que devia o pagamento de ISS à prefeitura do município e ofereceu um automóvel para a execução. A prefeitura considerou que o carro estava sobrevalorizado e era de difícil comercialização no mercado e entrou com ação para que fosse feita a penhora online, isto é, para que lhe fosse concedido acesso às informações bancárias do executado, por meio da Internet, de modo que, se houvesse dinheiro, este também pudesse ser penhorado. Em caso de concessão da penhora online, o juiz recebe uma senha e pode acessar todos os dados bancários do devedor e penhorar seu dinheiro ou aplicações financeiras.

De acordo com a FIESP, a penhora online foi introduzida pela Lei Federal nำ11.382, de 06 de dezembro de 2006, no artigo 655-A do Código de Processo Civil e significa:

“(...) ato executório que recai sobre dinheiro em depósito ou aplicação financeira. Trata-se da penhora eletrônica de sistema informatizado desenvolvido pelo Banco Central e firmado junto ao Poder Judiciário (Convênio Bacen-Jud), possibilitando a este a solicitação e o acesso às informações bancárias do executado, via Internet, com o fim de agilizar a execução, para efeito de penhora de dinheiro ou outros ativos financeiros. É o meio rápido, seguro e econômico de enviar ordens judiciais ao Sistema Financeiro Nacional, 
facilitando a tramitação de bloqueio e desbloqueio, transferência de quantias existentes em contas-correntes e outros ativos financeiros de clientes cadastrados. (...) De acordo com o Código de Processo Civil (art. 655-A), o juiz, a requerimento do exeqüente, requisitará à autoridade supervisora do Sistema Financeiro, preferencialmente por meio eletrônico, sobre a existência de ativos em nome do executado e informações acerca da existência, ou não, de depósito ou aplicação até o valor indicado na execução. O Banco Central, dessa forma, repassa automaticamente as ordens judiciais às instituições financeiras. Será garantida máxima segurança no trânsito das informações entre o Banco Central, as instituições financeiras e o Poder Judiciário, com o uso de tecnologia de criptologia de dados $^{17}$.

No entanto, $63 \%$ dos processos encontrados, desse tipo, foram negados pelo juiz. Todas as sentenças apoiam-se no mesmo argumento de que esse tipo de requisição, de algum modo, fere o direito de privacidade e que outros meios devem ser privilegiados e esgotados antes que a penhora online seja requerida. De acordo com o desembargador José Gonçalves Rostey:

"Longe de querer obstar a satisfação do direito fundamental à tutela jurisdicional efetiva, deve a penhora on-line, pelo sistema BACEN Jud, amoldar-se à proteção constitucional ao direito à privacidade, o qual amolda a intimidade, a vida privada, a honra e a imagem das pessoas ${ }^{18}$.

Ele lembra, ademais, que a penhora online pressupõe o esgotamento de todos os meios de obtenção de bens do devedor, pela Fazenda Nacional. No entanto, no caso desse processo, o desembargador teve voto vencido e a penhora foi concedida. Embora o devedor oferecesse um bem seu como objeto de penhora, a ausência de liquidez do veículo oferecido tornou-o não aceitável pela prefeitura.

\footnotetext{
${ }^{17}$ Estudo realizado pela FIESP/CIESP sobre penhora online e que se encontra disponível online no endereço: http://www.fiesp.com.br/sindical-juridica/pdf/penhora\%20on\%20line.pdf (acesso em 25 de março de 2012).

${ }^{18}$ Apelação nº: 0458674-57.2010.8.26.0000- Ribeirão Preto
} 
No mesmo sentido, a ministra Eliana Calmon também considera que esse recurso invade a esfera da privacidade: "O contribuinte ou o titular da conta bancária tem o direito à privacidade em relação ao seus dados pessoais, além do que não cabe ao Judiciário substituir a parte autora nas diligências que Ihe são cabíveis para demandar em juízo".

O desenvolvimento de um sistema que permita acesso direto às informações bancárias de um devedor possibilita substituir o recebimento de um bem com liquidez variável e duvidosa por dinheiro vivo, o que vai ao encontro dos interesses do credor. A conclusão da FIESP sobre a penhora online, é a de que ela "revolucionou o sistema de penhora no Brasil, dando maior presteza e segurança às execuções e ao sigilo das informações bancárias, sendo imprescindível seu constante aprimoramento para a sua adequada e regular operacionalização".

No texto "O Dinheiro na Cultura Moderna", Georg Simmel (1998) discorre sobre o caráter nivelador do dinheiro que, ao tornar-se a medida de todas as coisas, ocasiona a inevitável subordinação dos valores qualitativos aos quantitativos. Assim, "as coisas mesmas são desvalorizadas, num sentido mais geral, pela equivalência com aquele meio de troca válido para qualquer coisa"19. Em outras palavras, o caráter específico das coisas é prejudicado pela sua transformação no equivalente universal. Tudo passa a ser substituído pelo dinheiro, até penitências religiosas, ou multas no lugar de punições.

No entanto, se tudo pode ser substituído pelo dinheiro, nem tudo pode substituir o dinheiro. As coisas, desapossadas primeiro de suas especificidades

\footnotetext{
${ }^{19}$ SOUZA e ÖELZE ([1896]1998), p.32.
} 
por conta da equivalência ao dinheiro, começam a ter a própria equivalência ao dinheiro questionada. $\mathrm{O}$ valor monetário delas passa a ser difícil de estimar, no sentido de que, embora ainda possuam valor de uso para aqueles que a utilizam, foram desvalorizadas no mercado. Essa questão é verificável no caso de outro processo, do ano de 2011, em que foram oferecidos para penhora computadores adquiridos em dezembro de 2009. O credor justifica que, conforme Instrução Normativa 162/98, da Receita Federal, os equipamentos de informática apresentam taxa de depreciação de 20\% ao ano. Considerando essa taxa de depreciação, os equipamentos penhorados após dois anos de uso (2009/2011) já sofreram depreciação de 40\%, valor insuficiente para a garantia do juízo. O mesmo princípio pode ser aplicado para automóveis e outros bens comumente penhoráveis.

Desse modo, se um credor duvidar do valor do bem que lhe é oferecido, ele pode, por conta do desenvolvimento de um sistema como a penhora online, requisitar que o pagamento da dívida seja feito em dinheiro. As implicações desse sistema em relação à privacidade são claras. Embora seja um mecanismo aprovado por lei, os próprios juízes reconhecem os constrangimentos que pode causar. $\mathrm{Na}$ medida em que incide sobre a conta bancária e os ativos financeiros, o sistema pode bloquear a atividade econômica do(s) atingido(s). Os problemas decorrentes de alguém ter a conta bancária bloqueada são facilmente imagináveis em um momento em que as pessoas não mais costumam guardar dinheiro embaixo do colchão e em que todo o dinheiro transita pelos sistemas bancários.

É importante, sobretudo, lembrar que um dos propósitos para a transformação da privacidade em direito reconhecido por lei foi proteger 
determinados tipos de negócio e propriedades que, embora não fossem objetos materiais, eram julgados merecedores de proteção ${ }^{20}$. $\mathrm{O}$ entendimento de que as finanças deveriam estar sob essa proteção vem do fato de que a cifra bancária, a despeito do seu caráter imaterial, constitui posse como qualquer outra e deve ser, portanto, sigilosa. Assim, do mesmo modo que estranhos não podem entrar na casa de alguém sem permissão, também não podem violar suas informações bancárias.

O que se vê, portanto, nesse e nos demais conflitos, é como a tecnologia vem dar impulso a uma tendência oposta à vislumbrada nas origens do direito de privacidade: do privado vir a público. Essa mudança tem criado problemas como os relatados até aqui, mas pode gerar muitos outros, como veremos a seguir.

\subsubsection{Operações bancárias ilícitas via Internet}

Desde seus primórdios, as posses estiveram no núcleo do direito de privacidade. O desenvolvimento comercial e dos negócios teve papel fundamental na transformação da privacidade em direito. Isso ocorreu por volta do fim do século XIX, momento em que houve a demanda pelo surgimento de um novo direito fundamental do cidadão, construído a partir de direitos clássicos de proteção à pessoa e à propriedade, correspondente ao "direito de ser deixado em paz" ${ }^{21}$. Na verdade, a origem do direito de privacidade pode ser remontada à common law inglesa, que protegia o "direito à vida" ("the right to

\footnotetext{
${ }^{20}$ Cf. Warren e Brandeis, 1890.

${ }^{21}$ Idem.
} 
life"), isto é, garantia proteção em relação a intervenções físicas contra a vida e a propriedade da pessoa (que na época eram as terras e o rebanho). No manifesto considerado fundador do direito de privacidade, chamado The Right to Privacy, escrito em 1890, por Warren e Brandeis, os autores explicam que, gradualmente, o escopo desse direito foi expandido e passou a recobrir 0 direito de "gozar da vida", isto é, o direito de "ser deixado em paz" para aproveitá-la. O direito à liberdade passou a incluir o exercício dos privilégios de ser cidadão e o direito à propriedade estendeu-se para englobar todas as formas de posse - tangíveis e intangíveis. Assim, junto à expansão do direito à vida veio a própria expansão da concepção legal de propriedade: da propriedade corpórea, para a incorpórea, e então para a propriedade intangível, que incluía os produtos e processos da mente, os trabalhos de literatura e arte, as estimativas de lucro, segredos de negócios e valor de marca.

Portanto, conforme as formas de propriedade foram sendo refinadas, os meios de protegê-las tiveram de acompanhar esses desenvolvimentos. Até meados do século $\mathrm{XX}$, as principais ameaças ao direito de propriedade, ao menos no referente aos bens tangíveis, eram físicas: roubo e assalto. No caso do dinheiro, as formas de protegê-lo também eram físicas: guardá-lo em um cofre, em casa, ou em um banco, constituíam as medidas mais seguras para mantê-lo protegido. Para fazer um saque, também era necessária a presença física da pessoa, portadora de documentos que comprovassem ser ela a dona da conta. Após o desenvolvimento massivo dos sistemas de informação digitais, e do próprio sistema das finanças, o dinheiro deixou de estar presente em sua forma material, guardado em um cofre, e passou a ser representado por uma cifra digital em um sistema. Assim, foram criados os caixas 
eletrônicos, terminais de atendimento em que é possível retirar dinheiro e realizar algumas transações bancárias, apenas com o cartão do banco e a senha. Mais tarde, surgiu o Internet banking, o banco internético, que possibilita a realização de transações bancárias por meio da rede. $O$ que garante a segurança desse sistema é a criptografia dos dados. No entanto, embora a criptografia assegure a transação, o único mecanismo capaz de assegurar a autenticidade do usuário é a senha. Uma vez que ela seja violada, qualquer pessoa pode utilizar o sistema para transações. Assim, não há garantia contra fraudes e violações. Se o computador for invadido por um vírus, malware, ou qualquer outra forma de ataque, essa e outras senhas podem ser roubadas e transações ilícitas, realizadas.

E isso de fato tem ocorrido: $13 \%$ dos processos encontrados dizem respeito a operações bancárias ilícitas realizadas por meio da Internet, relatando transações, tais como pagamentos de contas e transferências, efetuadas sem o conhecimento do titular da conta bancária. Em um dos casos, uma correntista detectou em sua conta o pagamento de vários títulos desconhecidos pela rede, somando a quantia de $R \$ 9.738,49$. Disse que era a única pessoa com acesso à conta e à senha. O banco defendeu-se, alegando que a correntista não havia provado que os pagamentos foram feitos por terceiros e, na medida em que ela era a única possuidora da senha, ninguém mais a poderia utilizar. Disse ainda que o sistema de transações pela Internet é um serviço oferecido com total segurança e que falhas desse tipo seriam responsabilidade do usuário.

No entanto, a opinião do juiz foi que "não existe sistema inviolável" e que, em razão das inúmeras invasões aos computadores, "não são mais 
necessárias a posse do cartão e a senha para se ingressar na conta corrente de alguém". Portanto, "o banco-réu deve ser responsabilizado pelas quantias indevidamente sacadas, por terceiro, da conta corrente da autora". Nesse e em outros casos, além da reparação da quantia retirada, o banco foi condenado a pagar aos usuários indenização por danos morais.

Em outro processo, uma correntista do Bradesco teve o saldo negativado e o nome enviado aos órgãos de proteção ao crédito, após movimentação indevida de recursos de sua conta. Também nesse caso, o banco foi condenado a pagar a quantia retirada da conta e indenização por danos morais.

É possível notar que, na jurisprudência sobre esses conflitos, as sentenças não diferenciam as fraudes ocorridas no ambiente físico do banco, nos terminais eletrônicos, e aquelas efetuados pela Internet. $\mathrm{O}$ trecho em que o juiz desse último caso se apoia para emitir a sentença ilustra como há a convicção de que, no relativo às transações financeiras, a única mudança ocorrida diz respeito aos lucros dos bancos, que aumentaram a partir da emergência do Internet banking:

"Para nós está claro que no mundo virtual as instituições bancárias têm de ter a mesma segurança, solidez e credibilidade perante seus clientes que no mundo real - ou até mais, pelas características da rede. O custo de cada operação feita por clientes em uma agência bancária é cerca de duas vezes maior do que o custo da mesma operação feita por telefone e dez vezes maior que a feita por Internet. Se a extensão virtual de um banco representa tamanha redução de custos para esse banco, é justo esperar que reverta também em grandes investimentos na segurança do cliente virtual. O banco é integralmente responsável por qualquer dano ao cliente enquanto este estiver em seu espaço virtual. Um roubo virtual sofrido por um cliente quando operava no site de um 
banco é de responsabilidade desse banco. Por isso mesmo, as operações financeiras virtuais devem, obrigatoriamente, estar cobertas por seguro total".

Ao que tudo indica, o sistema bancário digital, embora tenha reduzido significativamente os custos dos bancos, não é seguro como o sistema tradicional. Se, antes da digitalização, a única forma de haver contas violadas seria por meio de assaltos a bancos, hoje, as formas de violação são em maior número e bem menos arriscadas do que um assalto tradicional.

Embora nesse tipo de conflito ocorra a mesma sensação de desproteção progressiva que temos com os outros e que eles sejam julgados a partir dos mesmos princípios, há que se notar uma diferença fundamental relativa à possibilidade de restituição do dano. No caso de dinheiro roubado, tanto em ambiente físico, quanto no virtual, o dano, de fato, pode ser reparado, na mesma moeda. O que se pretende, nesses casos, é ter o dinheiro de volta, e isso pode ser conseguido por meio dos processos. Porém, nos casos de difamação, e das demais ofensas aos direitos de personalidade (intimidade, privacidade, honra e imagem), o que está em jogo é a reputação do indivíduo. Ainda que haja tentativa de reparação do dano, com a identificação do ofensor e o recebimento de indenização monetária, não há como devolver a reputação perdida.

\subsubsection{Apagamento de registro na Internet}

Vimos que um componente fundamental da noção de privacidade envolve o controle sobre a informação pessoal. Para Simson Garfinkel (2001), uma grande ameaça a esse direito consiste no fim dos arquivos físicos e sua 
substituição por bases de dados digitais. Essas bases foram criadas por pesquisadores para permitir que cientistas em universidades e no governo tivessem facilidade para compartilhar pesquisas e recursos computacionais. Mais tarde, como é sabido, a rede se expandiu e passou a permitir que milhões de pessoas em todo o mundo também pudessem compartilhar informações com a mesma facilidade. Assim, houve, além da expansão dos registros digitais sobre cada indivíduo, a indexação dessas informações pelos mecanismos de busca. Nunca antes foram coletadas tantas informações sobre os indivíduos, tampouco essa informação foi tão facilmente acessível para tantas instituições, com propósitos tão diversos.

É preciso distinguir os tipos de informação pessoal sobre os indivíduos disponíveis na Internet. Primeiro, há informações que são inseridas pelos próprios indivíduos, como fotos, comentários e outros conteúdos, voluntariamente incluídos em alguma rede social, blog, ou qualquer outro site. Em segundo, há informações introduzidas nesses mesmos locais por outras partes, como amigos. Em terceiro, há as informações coletadas por empresas e outras instituições, com ou sem o conhecimento ou o consentimento dos atingidos. Como parte dessa categoria, há os dados capturados por cookies nos navegadores, os dados sobre buscas realizadas em sites como o Google, dados sobre hábitos de compra, etc.

Segundo Garfinkel, todo esse "rastro de dados" em geral escapa ao controle dos indivíduos. E, uma vez que eles possam ser incorretos, as pessoas ficam vulneráveis à punição e à retaliação por ações que não cometeram. Contudo, qual é exatamente a diferença entre ter um rastro digital de dados e um compilado de informações em outros meios? Antes, como 
agora, informações que desejaríamos esconder podem ser publicadas nos meios de comunicação. Uma notícia de jornal, revista ou até uma reportagem televisiva podem noticiar eventos que, do ponto de vista dos envolvidos, deveriam permanecer secretos. Porém, os próprios jornais e revistas começaram a migrar para o âmbito virtual e criar versões online de seus produtos. Além disso, o meio de publicação importa menos do que o de disseminação; isto é, uma informação pode ser retirada do mundo físico e depois ser disseminada pela Internet, passando a seguir, desse modo, as regras de circulação de informações desse meio.

Um tema comum em filmes e livros é o da mudança de identidade. $\mathrm{Na}$ ficção, diversos personagens se depararam com o desafio de extinguir os rastros identitários, apagar o passado e recomeçar a vida. Antes do surgimento da Internet, essa parecia ser uma tarefa menos complicada. Atualmente, se alguém comete um crime, é condenado e paga sua pena, pode exigir que o fato seja apagado dos registros virtuais? E se a pessoa for acusada de cometer um crime, mas for julgada inocente? Teria ela o direito de ter o incidente apagado dos informativos? Se ter sido "fichado" já é estigmatizante, como refazer a identidade quando essa informação está disponível na Internet?

No caso de Edilson Saez isso não foi possível. Ele afirma ter respondido a inquéritos policiais e processos criminais dos quais foi absolvido. No entanto, os dados relativos a esses inquéritos e processos ainda constam do banco de dados do Instituto de Identificação Ricardo Gumbleton Daunt ${ }^{22}$ (IIRGD), que fornece certidões de antecedentes criminais. Edilson requeria que essas

\footnotetext{
22 Órgão da Secretaria da Segurança Pública, que tem por objetivo informar a existência ou a inexistência de registro de antecedentes criminais, apresentando a situação do cidadão no exato momento da pesquisa nos registros informatizados do Instituto. Fonte: www. governoeletronico.net
} 
informações fossem excluídas do banco de dados do IIRGD, na medida em que, "estando provada sua inocência, não acha justo que continue a ser estigmatizado, pois a divulgação de dados criminais deve primar pela proteção à intimidade da pessoa".

No entanto, segundo o juiz, "nem mesmo no âmbito interno do Poder Judiciário há norma determinando o cancelamento de registro de processos pelos quais o interessado tenha sido absolvido ou tenham reconhecida extinta sua punibilidade, já que tais registros devem permanecer no cadastro para que estejam disponíveis ao atendimento de requisição judicial". Acrescenta que os dados do IIRGD são sigilosos, exceto para as autoridades que por disposição legal podem requisitá-los. O juiz afirmou que "os registros públicos não podem ser apagados. O que se garante é a privacidade do cidadão". Ele acrescenta que "não se pode apagar a realidade, cancelando a existência do processo, desde que incluída também a informação de seu arquivamento após trancada a ação penal". Dessa forma, o pedido de Edilson foi negado. O terceiro juiz com direito a voto reconheceu que, para preservar o direito de privacidade do cidadão, deveriam ser excluídos os registros penais no caso de absolvição. Contudo, reconhecendo que não haveria respaldo jurídico para manter sua opinião, ele optou por manter a sentença de não exclusão dos registros: "é imperioso constar que a douta maioria entende de forma diversa. Crê que os dados não podem ser apagados, a não ser se forem realmente indevidos".

Embora 0 juiz considere que 0 fato da absolvição constar da certidão evita que "o interessado passe o resto da vida sendo afetado por inquéritos ou processos há muito resolvidos em seu favor", talvez não seja isso que a experiência dos afetados mostre. 
Ainda que o banco de dados do IIRGD seja sigiloso, é sabido que qualquer empresa ou órgão público pode solicitar certidão de antecedentes criminais. Desse modo, uma vez que alguém tenha respondido a um processo criminal, dificilmente poderá ver-se livre do estigma, como mostra a história de uma mãe que se desentendeu com o filho e registrou boletim de ocorrência por lesão corporal. Após o desentendimento, tendo se reconciliado com seu filho, a mãe retirou a denúncia, o processo foi arquivado, de maneira que, judicialmente, nada mais constasse contra ele. Porém, dois anos após esse fato, cada vez que o rapaz é parado em uma blitz policial e tem sua ficha criminal consultada, acaba sendo submetido ao "constrangimento de perguntas indevidas" na frente de seus familiares, amigos e colegas de trabalho, o que, inclusive, o impede de trabalhar em uma empresa de segurança, pois seu nome ainda permanece no banco de dados do IIRGD.

Nesses casos, há ainda o consolo de que a informação criminal não é aberta ao público e seja revelada apenas em situações determinadas. Porém, o que ocorre quando os registros criminais de um indivíduo são divulgados na Internet? Em outro processo, um policial militar foi acusado do crime de roubo e desvio de cargas e sua foto, algemado, foi publicada em vários sites da Internet, no ano de 2002, e em uma reportagem televisiva. O policial, no entanto, foi absolvido por falta de provas e entrou com ação para que todos os sites excluíssem as reportagens de sua prisão. A reportagem veiculada pela TV não se encontra mais acessível. O acesso foi restrito aos que, no momento da exibição do programa, estavam sintonizados naquele canal. As notícias veiculadas na rede, contudo, continuam disponíveis nos sites e podem ser encontradas pelos mecanismos de busca. O juiz negou a ação e justificou que 
a matéria "só narra fatos reais e verdadeiros", não devendo, portanto, ser excluída.

Na Alemanha, houve processo semelhante, relativo a dois homens que assassinaram uma pessoa, foram condenados e cumpriram pena. Quando soltos, resolveram visitar a página da Wikipedia com o nome da vítima. Nela eles eram mencionados como os assassinos. Eles entraram com processo judicial para que seus nomes fossem removidos da enciclopédia online. Argumentaram que passaram pela prisão e pagaram o débito à sociedade e, portanto, querem que o incidente seja esquecido. Esse caso foi utilizado como exemplo na discussão acerca do "direito de ser esquecido" (the right to be forgotten), projeto de lei em curso no parlamento da União Européia. Esse direito garantiria que as pessoas tivessem controle sobre seus dados pessoais, e que pudessem requerer aos sites que corrigissem ou apagassem informações indesejadas. No entanto, a proposta gerou bastante polêmica entre especialistas no mundo. Jeffrey Rosen, professor de direito da Georgetown University, indignou-se dizendo que, na América, o caso dos assassinos alemães nunca seria apagado de nenhum registro virtual, pois constituiria grave violação à liberdade de expressão. "Nós não apagamos as pessoas da história porque elas possuem um direito de serem esquecidas" ${ }^{23}$, disse ele.

De acordo com Viviane Reding, vice-presidente da Comissão Europeia e responsável pela proposta, as ações online - e-mails, comentários em blogs, compras, consumo de pornografia, fotos, entre outras, estão presentes em bases de dados controladas na grande "nuvem". Essa informação pode 
permanecer nesses servidores para sempre. Esses dados são inseridos nesses servidores com o consentimento das pessoas que resolvem utilizar o serviço das empresas e aceitam os termos do contrato estabelecido. Porém, segundo Reading, as pessoas devem ter controle sobre essa informação, de modo que possam apagar registros online indesejados ${ }^{24}$.

Em outro caso desse tipo, o empresário Eduardo Bottura entrou com ação contra UOL, Microsoft, Yahoo! e Google, para que fossem eliminadas notícias que mostravam foto sua quando foi preso, seguidas de comentários que estariam denegrindo sua imagem, "com clara utilização indevida de seu nome e imagem, violando com isso, seus direitos de personalidade". Ele pedia a remoção de blogs que continham notícias sobre ele e a supressão dos resultados de busca com a palavra-chave de seu nome.

Segundo informações do site Conjur e do TJ-MS, o empresário Eduardo Bottura responde por 239 ações por litigância de má-fé contra desafetos, advogados e até magistrados. Morador da cidade de Anaurilândia, ele entrou com essas ações motivado pela punição aplicada pela Corregedoria do Tribunal daquele estado à ex-juíza Margarida Elisabeth Weiler, da Comarca de Anaurilândia, acusada de conceder diversas liminares em favor de Bottura, em situações suspeitas. Após esse incidente, a juíza foi aposentada compulsoriamente.

"No início, os alvos do empresário eram só desafetos. Assim que seu processo de separação começou, Bottura, que vende produtos pela Internet e foi investigado em São Paulo, Tocantins e Mato Grosso do Sul por lesão a consumidores, passou a usar a Justiça para tirar o sono da ex-mulher e do ex-

\footnotetext{
${ }^{24}$ Idem.
} 
sogro. Patrícia Bueno Netto e Adalberto Bueno Netto, proprietários de empreendimentos imobiliários de luxo em São Paulo, chegaram a admitir Bottura como investidor em um de seus negócios, mas se arrependeram depois. O fato culminou com as investidas judiciais do empresário em busca de bens, participação nos negócios, e até uma pensão alimentícia de $R \$ 100$ mil a ser paga pelo ex-sogro, concedida por liminar da ex-juíza Margarida Weiler, imediatamente derrubada pelo TJ-MS. (...) Conforme a corte foi derrubando as liminares conseguidas pelo empresário em primeiro grau, os próprios desembargadores também entraram na lista de alvos. Foi quando começaram

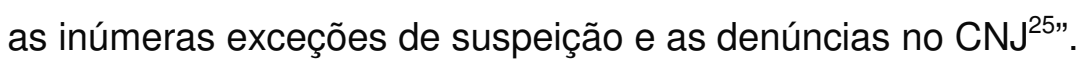

Bottura e suas empresas de comércio online respondem por mais de 700 processos em todo o país e mais de uma dúzia de inquéritos policiais por crimes contra o consumidor. Segundo investigações do Procon de São Paulo, Bottura é sócio de empresas acusadas de enviar boletos de cobrança a consumidores que jamais compraram nada com elas. As empresas, com sedes em diversos estados receberam, até o começo de 2009, mais de mil reclamações dos consumidores só no Procon-SP.

No processo aqui examinado, Bottura pedia que as informações sobre seu histórico de violações fossem retiradas de diversos sites da Internet e que seu próprio nome fosse bloqueado nas buscas. Ele ganhou a causa em primeira instância, mas as empresas apelaram, alegando que: 1) nem toda crítica veiculada na Internet merece ser reprimida; 2) que não há responsabilidade dos sites pelos conteúdos que ali são inseridos por terceiros; 3) não há como atingir o resultado almejado uma vez que os sites de busca não são os provedores ou criadores desses conteúdos; 4) enquanto as

\footnotetext{
${ }^{25}$ Consultor Jurídico (www.conjur.com.br). Matéria intitulada "Empresário acumula 239 condenações por má-fé" publicada em 04 de outubro de 2010.
} 
supostas páginas ofensivas estiverem na rede poderão ser acessadas por outros meios que não os sites de busca; 5) inexiste ferramenta de censura ou filtro capaz de excluir determinados critérios de busca; 6) não se pode utilizar o sistema de busca para excluir resultados futuros ainda não inseridos na rede.

Entretanto, o juiz defendeu a tese de que houve violação da privacidade de Bottura e que os conteúdos publicados nesses sites foram danosos a sua imagem e honra:

"Assim, a existência de conteúdo com potencial ofensivo que ultrapassa os limites do razoável exige a compatibilização, pelo princípio da proporcionalidade, do direito fundamental de liberdade expressão com o direito à imagem da pessoa, de molde a justificar a remoção como determinada".

O juiz apenas retrocedeu no que diz respeito a filtrar os resultados de busca com o nome do autor, devendo este indicar à empresa o endereço (url) do conteúdo ofensivo para que o juiz autorize a remoção.

Assim, nesse caso, o histórico de violações do empresário não foi considerado de "interesse público" e as críticas tampouco julgadas liberdade de expressão. Isso mostra que, mesmo no estado de São Paulo, não há consenso acerca desse tópico. O direito de ser esquecido não é concedido a todos. $E$ mesmo quando é, como nesse caso, ele não garante que os registros sejam removidos para sempre. Ainda é possível encontrar todo o histórico de Bottura ao digitar seu nome em um sistema de busca, incluindo sua foto, preso, com uma placa de identificação.

No caso Operação Confraria, o advogado Nelson José Comegnio entrou com ação contra uma série de sites jornalísticos para que reportagens que noticiavam sua prisão preventiva fossem retiradas da Internet. $\mathrm{O}$ advogado foi 
preso junto com seu sócio, o empresário Humberto Carlos Chaim, na cidade de Bauru, sob acusação de promoverem um esquema fraudulento envolvendo a casa noturna "Dolce", da qual eram donos, que fora inaugurada há três anos no antigo prédio da "Cervejaria dos Monges", da qual também eram proprietários. Segundo a reportagem, o novo empreendimento teria sido registrado pelos empresários em nome de "laranjas", como forma de burlar o Fisco e a cobrança judicial de dívidas trabalhistas e com fornecedores deixadas pela cervejaria, que havia fechado em 2006. Os sócios foram investigados por dez meses pela Polícia Federal que, durante o processo, utilizou escutas telefônicas e monitoramento de outros meios de comunicação, como MSN, autorizados pela Justiça Federal, que comprovaram o esquema de sonegação de impostos.

No processo consultado, o advogado Nelson afirmou que as acusações eram falsas e "que viu seu nome sendo lançado na mídia como se fosse criminoso. Disse que, por ser advogado, não pode ter o nome envolvido em prisões e acusado da prática de fraude sem direito à defesa. Alega que ninguém pode ser considerado culpado sem existir título executivo judicial com trânsito em julgado. Destaca que, no caso, houve inquérito policial e decreto de prisão temporária, mas sequer existe ação". Em razão disso, requer a exclusão das matérias jornalísticas "ofensivas" à sua honra e reputação.

Porém, diferente do caso Bottura, nesse caso, o juiz entendeu que as reportagens "apenas pretendiam chamar atenção à população sobre supostos ilícitos ocorridos" e que "parece denunciar fato de importância social". Portanto, novamente há resultados diferentes para conflitos semelhantes: o direito de ter apagado um registro desfavorável, em ambos os casos, é condicionado ao "interesse público" sobre a informação. No entanto, embora conflitos 
semelhantes tenham obtido sentenças judiciais diferentes, os resultados reais provavelmente serão muito parecidos.

Os registros que os personagens desse capítulo gostariam que fossem apagados fazem parte do que eles entendem como o conjunto de suas informações pessoais, sobre as quais teriam propriedade, de acordo com o direito de privacidade, e portanto, acreditam que devem poder controlar. Contudo, no presente, esse direito não vem sendo negado apenas a eles. A informação pessoal segue um percurso no qual é deslocada da posse do indivíduo para outros domínios. Resta saber se esse deslocamente ocorre apenas em função da própria dinâmica da Internet, ou se haveria outras razões para explicá-lo.

\subsubsection{Operações de marketing, venda e utilização indevida de dados de consumidores}

Em um ambiente online cada vez mais vigoroso, no qual indivíduos, comunidades, instituições e corporações geram conteúdo, experiências, interações e serviços, a moeda principal é a informação, incluindo aquela sobre as pessoas. Muitos ainda se surpreendem quando notam que os anúncios oferecidos ao lado de sua caixa de entrada de email estão sincronizados com o conteúdo das mensagens ali presentes. Irritam-se quando recebem telefonemas para oferecimento de cartões ou planos de celulares indagando-se como essas empresas tiveram acesso às suas informações pessoais. Ou, ainda, espantam-se quando recebem a oferta de um produto sobre o qual recentemente buscaram informações na Internet. Essas ações vêm sendo cada 
vez mais utilizadas pelas empresas que perceberam poder lucrar com as informações que circulam pelo mundo virtual.

Segundo a Forbes, o Twitter contratou recentemente duas empresas de pesquisa de mercado para analisar informações de usuários e depois vendêlas para empresas interessadas. Em entrevista para o jornal britânico Daily Mail, Nick Pickles, diretor da Big Brother Watch Campaing Group ${ }^{26}$, disse: "As pessoas podem achar que seus tweets são sua propriedade pessoal, mas esse acordo deixa claro que não. É evidente que se você não paga por um serviço, você não é o cliente, você é o produto". Acrescentou que os únicos dados vendidos são os públicos, isto é, aqueles que os usuários optam por revelar em suas opções de privacidade e que "o Twitter realmente se tornou uma fonte valiosa de informação e que muitas companhias querem fazer uso dela". Mas não apenas o Twitter. O Facebook também se tornou alvo de empresas que procuram lucrar com os dados dos usuários. "Facebook e Google são agora claramente os líderes desse tipo de anúncios”, disse lan Maude, analista da empresa Enders ${ }^{27}$, para o Financial Times $^{28}$. A tecnologia "re-targeting", em que os itens pesquisados por um alguém são gravados e reaparecem em diferentes anúncios de sites tem sido muito útil para os anunciantes encontrarem seus alvos entre os usuários da rede. Os anúncios em redes sociais, como o Twitter e o Facebook, aumentaram 75\% em comparação com o ano de 2010, segundo dados do Financial Times.

\footnotetext{
${ }^{26}$ Organização não-governamental britânica fundada em 2009 para a defesa das liberdades civis e proteção da privacidade.

${ }^{27}$ Empresa de pesquisa britânica em mídia, entretenimento, e telecomunicações na Europa.

${ }^{28}$ Uma das maiores empresas do mundo no ramo das notícias sobre o mundo corporativo e economia internacional.
} 
O passo dado pelo Twitter representa uma tendência nas operações de marketing. À medida que os indivíduos inserem cada vez mais informações pessoais na rede, mais as empresas se interessam por fazer uso dela. Assim, cada vez mais as companhias buscam monitorar os hábitos, opiniões e comportamentos dos usuários de Internet, para conquistar mais consumidores, ou avaliar a recepção de um produto no mercado. No entanto, embora na maior parte das situações essa captura de informações passe despercebida, ou não seja objeto de preocupações, muitas vezes pode desencadear conflitos. Isso nos faz retornar à questão do anonimato. A partir do momento em que a Internet se tornou uma plataforma de negócios, alguns dos princípios que nortearam sua idealização começam a ser desafiados, e ela passou a incorporar elementos importantes do mundo mercantil, como a ideia de personalização das mercadorias consumíveis. Como explicam Boltanski e Chiapello (2009), a demanda por flexibilidade, autonomia e autenticidade, presente na crítica constituída pela geração de maio de 1968, foi "desarmada" e incorporada ao que os autores chamam de "novo espírito do capitalismo". Uma das respostas a essa crítica foi "transformar em produtos bens e práticas que - em outro estado - ficavam antes fora da esfera do mercado" (p.444). Assim, em face das reinvindicações de autenticidade, "produtos diferenciados" e aparentemente exclusivos passaram a ser oferecidos ao consumidor, para que fosse reduzida a impressão de massificação.

Portanto, não constitui novidade o fato de as empresas buscarem a personalização cada vez maior de seus produtos nos negócios online. A diferença é que agora dispõem de mecanismos mais eficientes para saberem o que cada indivíduo deseja. Como afirma Eli Pariser: 
"a fórmula dos gigantes da Internet para essa estratégia de negócios é simples: quanto mais personalizadas forem suas ofertas de informação, mais anúncios eles conseguirão vender e maior será a chance de que você compre os produtos oferecidos. A Amazon vende bilhões de dólares em produtos prevendo o que cada cliente procura e colocando esses produtos na página principal de sua loja virtual”29.

Entre os processos analisados, temos o exemplo de um homem que entrou com ação contra a empresa Telefônica, por ter recebido em sua casa correspondência oferecendo uma conexão de banda larga que seria superior à sua atual conexão, cuja velocidade vinha mencionada na correspondência. O homem queixou-se de violação de privacidade, na medida em que não entendeu como a Telefônica poderia ter acesso aos dados de sua conexão, que era feita por outra empresa. A ação foi negada, na medida em que o juiz não entendeu que houvesse violação de privacidade nesse caso.

Em outra ação civil pública, a Anadec $^{30}$ entrou com liminar para que a concessionária Renault retirasse de seu site informações cadastrais de clientes que estariam sendo repassadas a terceiros. A Renault defendeu-se alegando que a remessa de dados do consumidor a terceiros não afronta o CDC e que, ademais, estava prevista em sua política de privacidade. Além disso, afirmou que a solicitação de dados pessoais é requerida apenas quando há solicitação de um serviço e não para todos os que acessam seu site. O juiz acatou a argumentação e a Renault venceu a causa.

Obter informações sobre os hábitos de consumo dos indivíduos também é útil para concessão de crédito e proteção contra a inadimplência. Esse

\footnotetext{
${ }^{29} 2012$, p.13

${ }^{30}$ Associação Nacional de Defesa da Cidadania e do Consumidor.
} 
argumento foi utilizado pelo juiz para negar ação civil pública impetrada pelo Ministério Público do Estado de São Paulo contra a Associação Comercial de São Paulo, por conta da manutenção de um banco de dados com o registro dos negócios realizados ou tentados pelos consumidores. O banco de dados possui informações, de um período de 25 anos, registradas sem 0 conhecimento dos consumidores. A ação foi negada a partir do argumento de que a manutenção desse cadastro é útil à sociedade, por reduzir a inadimplência. Além disso, "o caráter público dos arquivos de consumo" é algo garantido em lei pelo Código de Defesa do Consumidor ${ }^{31}$. O outro juiz relator da sentença, cujo voto foi vencido, ressaltou que, apesar de ser permitida por lei, essa prática "não possui transparência, tampouco parâmetro de lealdade com o consumidor, porquanto a inserção das informações, a despeito de, em tese, não ser prejudicial, viola o art. 43, §2ํ do CDC”. Portanto, em seu juízo, essa prática representaria clara violação do direito de privacidade dos consumidores. Porém, seu voto não prevaleceu e o banco de dados continua em operação.

Existe uma série de outros exemplos dessas práticas, como a confecção de cartões de fidelidade para o registro dos hábitos de compra de consumidores, a coleta e a venda de dados de cartões de crédito, ou a venda de cadastros de devedores. Todas essas ações mostram que as práticas comerciais de retenção, repasse e venda de dados de consumidores tornaramse não apenas comuns, mas aceitas como práticas legais que não violam a privacidade. Entende-se que os hábitos de consumo sejam informações

31 Referindo-se ao art. 43, §2 CDC, que assegura que: "a abertura de cadastro, ficha, registro e dados pessoais e de consumo deverá ser comunicada por escrito ao consumidor, quando não solicitada por ele". Fonte: www. jusbrasil.com.br 
públicas, embora não haja nenhum outro argumento que ofereça razões para sua publicidade, senão o impulso aos negócios online. Estes, tendo como base principal a informação, não apenas desbancam formas tradicionais de negócio, mas veem a própria privacidade como um entrave.

\subsubsection{Apropriação indevida de imagem, direitos autorais e propriedade intelectual}

Entre as chamadas "extensões do indivíduo", que os juristas Warren e Brandeis afirmam fazer parte do direito de privacidade, incluiam-se os retratos das pessoas privadas, que já naquela época, começavam a ter uma circulação indesejada. Conforme os autores,

"as fotografias instantâneas e a empresa jornalística invadiram o recinto sagrado da vida doméstica e privada, e numerosos equipamentos técnicos ameaçam tornar verdadeira a máxima de que o que é sussurrado no armário deve ser proclamado nos telhados. Por anos há o sentimento de que a lei deveria prover algum remédio para a circulação não autorizada de retratos de pessoas privadas; e o mal da invasão da privacidade pelos jornais, há tanto tempo sentido como incômodo, foi somente agora discutido de forma apropriada" ${ }^{\text {"32. }}$.

Desse modo, uma das formas de "ser deixado em paz" dizia respeito à proteção das imagens e fotografias das pessoas privadas. Se já em 1890 os jornais constituíam uma ameaça à privacidade, hoje essa preocupação tornase muito maior em razão do potencial disseminador de informações da Internet, muito mais amplo do que o jornal ou qualquer outra forma de mídia conhecida.

\footnotetext{
32 1890, tradução minha.
} 
Mas, as semelhanças entre o passado e o presente vão além. A virada do século XIX para o XX guarda semelhanças curiosas com o momento atual, não por mera coincidência. Houve, em ambos os momentos, importantes revoluções tecnológicas. O primeiro, como mostra Nelson Schapochnik, marcado por avanços científicos prodigiosos e progressos tecnológicos espetaculares nas áreas dos transportes, eletrificação, indústrias químicas, controle de doenças que alteravam a sociedade de modo profundo e irrevogável ${ }^{33}$. Também foram notáveis os avanços na área das comunicações, representado pela fotografia e a imprensa. No segundo momento, próximo à virada do século XX para o XXI, temos o surgimento das chamadas Novas Tecnologias da Informação, as quais, por muitas razões, transformaram de maneira permanente as práticas sociais.

Curiosamente, como nota o autor, o momento de notável modernização presenciado no início do século XX, no Brasil, coincidiu com a proliferação de cartões postais e álbuns de família, como um sintoma da progressão do individualismo. Fotos eram arranjadas em cenários com objetos que representavam o mundo moderno, como a emprestar suas próprias características entusiásticas aos fotografados. Roupas eram cuidadosamente escolhidas para disfarçar a condição social do fotografado. Tudo isso foi tornado possível graças ao lançamento da primeira Kodak, em 1888, que eliminou a necessidade de um fotógrafo profissional e estimulou a prática do fotoamadorismo. Desse modo, por trás dos retratos em "balões e aviões ilusórios que cruzavam os céus de Poços de Caldas", havia o desejo de exaltação de ícones da modernidade, que alimentavam "as fantasias e a auto-

\footnotetext{
${ }^{33} 1998$, p.514.
} 
estima do retratado, emblematizando um desejo individual de expansão bem como a apropriação privada da paisagem na forma de um souvenir"34.

É possível reconhecer nas formas atuais de registro e exibição das imagens, efetuadas por meio da Internet, um desejo semelhante de aumentar a auto-estima e de obter distinção, talvez também guiado pelo entusiasmo com as novas ferramentas técnicas disponíveis para brincar com a própria imagem. Do mesmo modo que antes havia manipulação do cenário e das roupas, para disfarçar a condição social, hoje, as tecnologias permitem que as imagens sejam amplamente manipuladas, de modo a facilitar a exibição, nas redes sociais, dos símbolos de felicidade, sucesso e beleza.

Porém, enquanto o cartão-postal era feito para encontrar um destinário específico e conhecido, a imagem virtual é feita para tornar-se disponível para o mundo. Isso ocorre, tanto por conta da própria estrutura da Internet, que favorece a disseminação da informação, quanto em decorrência das motivações por trás da exibição, que se transformaram ao longo do tempo. Se, antes, como agora, tirávamos fotos e as exibíamos, sobretudo, para agradar os outros, é notável como esse desejo adquire contornos diferentes em cada momento. O postal, assim como o álbum de família, circulava num registro muito específico e não perdia o caráter de intimidade. O álbum era mostrado aos convivas que frequentavam a casa e os postais eram enviados a amigos de longa data. A tentativa de distinção e associação a símbolos de sucesso era claramente ligada a uma genuína demonstração de apreço ao destinatário; no caso do postal, como uma forma de dizer: "passei por esse lugar tão magnífico e lembrei de você". Com o álbum de família, procurava-se, sobretudo, reforçar

\footnotetext{
${ }^{34}$ Idem, p.446.
} 
os laços, a proximidade com aqueles com quem se partilhava de um pedaço da intimidade.

No caso da exibição de imagens na Internet, na medida em que o destinatário é a rede, não há alvo específico. A aprovação, medida pelo número de curtidas, é quantitativa, isto é, quanto mais pessoas apertarem o botão "curtir", maior o sucesso da publicação. O objetivo, portanto, é agradar a "gregos e troianos" e ampliar as conexões, com a transmissão de uma imagem ideal capaz de gerar bons frutos.

No entanto, em ambos os casos, trata-se do esforço para divulgar imagens que enaltecem o retratado. Porém, a despeito de todo o investimento para a construção de imagens elogiosas, muitas vezes, é o contrário que ocorre: isto é, são compartilhadas na rede imagens desabonadoras, causando grandes prejuízos à vida do fotografado. Os casos que discutiremos a seguir mostram o impacto que uma imagem íntima, retirada de seu contexto e disseminada numa rede mundial, pode ter na vida de alguém, chegando ao limite de um desfecho trágico.

O primeiro caso ocorreu em setembro de 2006, tendo como protagonista a ex-apresentadora de TV Daniella Cicarelli, que foi flagrada por um fotógrafo em situação íntima com seu namorado. O vídeo apareceu primeiramente no YouTube e foi retirado do ar poucas horas após a divulgação. No entanto, houve tempo suficiente para que ele se espalhasse pela rede e fosse perdido o controle sobre sua exibição.

O casal entrou com ação judicial, exigindo que o vídeo fosse retirado da rede. Após trâmite do processo, a tese que prevaleceu na 4ª Câmara de Direito 
Privado do Tribunal de Justiça do Estado de São Paulo foi que Daniella Cicarelli e Renato Malzoni têm o direito de ter a imagem e a privacidade resguardadas. A comissão julgadora decidiu, por maioria de votos, que três sites retirassem do ar as cenas íntimas do casal namorando na praia. De acordo com o juiz relator, o direito de imagem é protegido pela Constituição Federal Brasileira e pelo Código Civil Brasileiro e não há provas de que as imagens foram feitas com o consentimento de Daniella e de seu namorado. Além disso, foi afirmado que a intenção do paparazzo era expor a intimidade do casal e que cabia à Justiça resguardar a vida íntima e a imagem das pessoas, o que é um direito constitucional. Com efeito, esse tipo de divulgação de imagens, que requer consentimento expresso dos envolvidos, ofenderia direitos como honra, recato, privacidade, intimidade. No mais, de acordo com o Desembargador Teixeira Leite, "uma coisa é a usurpação do nome ou imagem e outra é que, pela utilização dos mesmos, se exponha a pessoa ao menosprezo ou ridículo".

Por outro lado, houve a tese do revisor Maia da Cunha, afirmando que não houve, por parte do casal, preocupação em preservar o direito de imagem. "Os agravantes, como pessoas públicas, ao resolverem agir como agiram, abriram mão da intimidade e da privacidade". "Elas sabiam que numa praia, com tanta gente, corriam o risco de não terem a sua imagem preservada", acrescentou o revisor.

Por fim, o desembargador Ênio Santarelli Zuliani concedeu a liminar obrigando todos os sites a retirarem do ar as cenas de Daniella Cicarelli e Renato Malzoni namorando em Cádiz; no entanto, mesmo o vídeo tendo sido retirado de sua fonte, isto é, do YouTube e dos outros sites que o publicaram, a 
sua apropriação foi feita instantaneamente pelos milhões de usuários que tiveram acesso às imagens. Dessa forma, mesmo não sendo mais encontrado nesses locais, o vídeo ainda pode ser compartilhado na rede, pelos usuários, e assim sua proliferação escapa ao controle da ação judicial.

Daniella Cicarelli recorreu às instâncias tradicionais de proteção; porém, ainda que a Justiça tenha sido acionada e ela tenha obtido ganho de causa em primeira instância, a decisão judicial pouco pôde fazer pela preservação de sua intimidade. O vídeo da apresentadora, com imagens íntimas, foi disseminado na rede e, ainda que retirado do YouTube, pôde continuar sendo compartilhado por muitos usuários por meio de outros sites.

Outro caso notório ocorrido no Brasil, em que houve perda de privacidade por meio de utilização indevida de imagem online, teve como protagonista a advogada da TV Record Kelly Cinelli. Com a câmera de seu celular, ela gravou um vídeo de si própria masturbando-se no banheiro da empresa e enviou para um colega de trabalho pela rede da empresa. $O$ conteúdo foi capturado pelos funcionários da área de tecnologia da Record e postado na Internet. A advogada entrou com processo contra a empresa Google para que o vídeo fosse retirado dos resultados de busca do site e obteve ganho de causa, tendo o Google retirado esse conteúdo de suas buscas. No entanto, como no caso Cicarelli, antes de ser retirado dos resultados de busca do Google, o vídeo foi apropriado por muitos usuários e pôde ser compartilhado. Assim, por mais que o Google o tenha retirado de seus resultados de busca, cedo ou tarde ele voltará a ser encontrado, seja pelo próprio Google ou por outros buscadores. 
Outro tipo de caso bastante comum é a apropriação de fotos para criação de páginas enganosas em redes sociais, seja para difamar pessoas, ou para praticar algum tipo de atividade ilegal com a utilização de identidades falsas. Ficaram conhecidos, recentemente, casos em que meninas enviaram fotos íntimas pela Internet e passaram a sofrer bullying. Em 2012, Amanda Todd, uma canadense de 15 anos, suicidou-se após ter sido vítima desse tipo de assédio desde os 12, quando mostrou os seios para um homem em um bate-papo virtual. Um ano depois, o homem contactou-a pelo Facebook, ameaçando postar na Internet sua foto em topless "caso ela não fizesse um show" para ele. O estranho sabia tudo sobre ela: endereço, escola, amigos, nome dos parentes. Não tendo a chantagem surtido efeito, o homem criou um perfil nessa rede, com a foto de Amanda mostrando os seios. A menina entrou em depressão, desenvolveu transtorno de ansiedade e começou a cortar-se. Mudou de cidade e de escola, mas o bullying permaneceu, tendo sido até espancada por colegas (a cena foi gravada e postada no Youtube). Em 2012, ela cometeu suicídio.

No Brasil, a estudante Giana Laura Fabi, de 16 anos, da cidade de Veranópolis, no Rio Grande do Sul, enforcou-se com um cordão de seda após foto sua mostrando os seios ter sido postada na Internet. Um rapaz de 17 anos confessou ter salvado a foto em seu computador e enviado para alguns amigos. A imagem espalhou-se pela rede, destruindo a reputação de Giana. Quatro dias antes, Julia Rebeca, estudante piauiense de 17 anos, também se matou por motivo semelhante. Não suportou o assédio sofrido após vazar na Internet um vídeo em que aparecia fazendo sexo. Ambas despediram-se pelo Twitter. 
No entanto, apesar desses conflitos e das preocupações resultantes, o que se observa é o crescimento exorbitante das formas de exposição de imagens próprias e alheias por toda a rede. O segmento que mais cresceu no âmbito dos negócios virtuais foram os sites dedicados à publicação de fotos, como o Instagram, o Snapshot e o Selfie, o último especializado em autoretratos virtuais.

Um "selfie" tirado pelo presidente dos EUA, Barack Obama, junto com a primeira-ministra da Dinamarca, Helle Thorning-Schmidt, e o primeiro-ministro da Inglaterra, David Cameron, no funeral de Nelson Mandela ${ }^{35}$, suscitou polêmica e foi alvo de diversas críticas. O selfie dos líderes de estado pareceu fútil e inadequado, sobretudo por ter sido feito em uma ocasião fúnebre. A ministra da Dinamarca defendeu-se dizendo que os chefes de estado, assim como todo mundo, também querem divertir-se.

Tão inusitado quanto o "selfie" dos chefes de estado foi o caso de duas quadrilhas do litoral de São Paulo, que criaram um perfil no Facebook para exibir seus feitos. Ao que tudo indica, ambas competiam para disputar quem realizava os maiores roubos; assim, os produtos de sua ação eram postados no Facebook para instigar a inveja da rival ${ }^{36}$. A exibição dos feitos na rede social, entretanto, custou-Ihes a prisão já que foi decisiva para que a polícia as encontrasse.

\footnotetext{
${ }^{35} \mathrm{O}$ ex-presidente da África do Sul e líder antiapartheid faleceu no dia 05/12/2013. A cerimônia religiosa de sua despedida, durante a qual Barack Obama e os outros líderes de estado tiraram o retrato, ocorreu no dia 10/12/2013, no estádio Soccer City, em Johanesburgo.

${ }^{36}$ Apologia ao crime na web: um curto caminho para a prisão. Diário do Litoral. 24/11/2013.
} 
O surgimento de novas tecnologias é capaz de produzir efeitos libertadores, mas também disruptivos sobre a vida das pessoas. Como afirma Nicolau Sevcenko,

“(..) só um olhar que se arrogasse desprendido e imune aos efeitos turbulentos dessa transição das condições materiais de reprodução do cotidiano, poderia analisá-la pelos seus supostos efeitos de organização, racionalização, controle e harmonização do mundo contingente. O que ocorre é o contrário: os novos recursos técnicos, por suas características mesmo, desorientam, intimidam, perturbam, confundem, distorcem, alucinam. No mínimo porque as escalas, potenciais e velocidades envolvidos nos novos equipamentos e instalações excedem em absoluto as proporções e as limitadas possibilidades de percepção, força e deslocamento do corpo humano"37.

Nesse sentido, a popularização da Internet e das novas tecnologias da informação, a despeito do seu potencial extraordinário de disseminar informações e ampliar os canais de comunicação, trouxe consigo uma série de "efeitos turbulentos". Entre eles, os que despertam maior preocupação no presente são as ameaças à privacidade, por razões já discutidas. Nesse primeiro capítulo procuramos conhecer essas ameaças e como elas se apresentam em contexto brasileiro. A constatação mais evidente que se poderia fazer ao examinar esse cenário é a de que a privacidade parece ser uma forma em decadência e as causas de sua derrocada estariam imediatamente vinculadas à própria dinâmica das novas tecnologias.

Entretanto, percebemos que o fenômeno em questão teria um prelúdio mais antigo do que a introdução da nova forma técnica ao cotidiano. Desse modo, o cenário aqui apresentado seria uma espécie de culminação de um

\footnotetext{
${ }^{37} 1998$, p.516
} 
longo processo de transformação nos sentidos do privado que só poderia ser entendido a partir de um olhar que considerasse sua história. Para isso, decidimos remontar às origens do direito de privacidade e tentar reconstituir as principais direções que esse processo tomou ao longo do tempo, para que, ao final da tese, pudéssemos retornar ao presente com um novo olhar sobre 0 problema.

O texto considerado como o manifesto fundador do direito de privacidade foi escrito em 1890, nos Estados Unidos, pelos juristas Samuel Warren e Louis Brandeis. O mote fundador do artigo foi a percepção de que os desenvolvimentos no mundo dos negócios e as novas invenções técnicas, bem como uma transformação na vivência do privado tornaram clara a necessidade de ampliação do escopo dos direitos civis para proteção da esfera doméstica ou privada. Para desenvolver seu argumento, os autores partem de uma analogia com o direito de propriedade, tanto para mostrar as semelhanças com a privacidade, quanto para estabelecer as especificidades da última. Dizem eles: "o reconhecimento da natureza espiritual do homem, de seu intelecto e seus sentimentos", tornaram necessária a "expansão da concepção legal de propriedade" para abarcar também as formas de posse intangíveis, mostrando como, "com o avanço da civilização, ficou claro para os homens que apenas uma parte da dor, do prazer e do lucro residiam nas coisas físicas".

Sendo os objetos da privacidade - a esfera doméstica e sua personalidade - propriedade dos indivíduos, não estariam já protegidos pelos direito de propriedade intangível? Warren e Brandeis perceberam, entretanto, que havia uma diferença entre os direitos de propriedade (tangível e intangível) já existentes e a privacidade, isto é, de que esta última não era simplesmente 
mais uma forma de propriedade como qualquer outra, fato que impossibilitava sua consideração equivalente.

Desse modo, embora a vida privada fosse propriedade do indivíduo, havia nela algo de específico que a ideia de propriedade simples já não era capaz de abarcar. Essa especificidade, captada pelos autores, diz respeito à diferença entre a casa como como propriedade privada do indivíduo, e a casa como lar, esfera doméstica e recinto de um tipo de existência distinta da que havia no espaço público. A partir dessa percepção, o próprio direito teve que ser estendido para dar conta da nova esfera de vida que clamava por reconhecimento.

Percebeu-se, assim, que as leis existentes, de difamação e de direitos autorais já não bastavam para dar conta dos novos sentidos que o privado vinha assumindo. Em relação ao primeiro caso, argumentam os juristas: "não é contra a violação do caráter individual que a prevenção se faz necessária, mas contra a violação da privacidade. (...) O direito de privacidade proíbe não apenas que se faça um retrato incorreto da vida privada (que seria difamação), mas sim que qualquer retrato dela seja feito" (p.9).

De modo análogo, a privacidade também seria diferente dos direitos de propriedade intelectual:

"Um homem menciona em um carta para seu filho, ou em seu diário, que ele não jantou com sua esposa em determinado dia. Ninguém em cujas mãos essa carta caísse poderia publicá-la para o mundo, mesmo se a posse do documento the fosse legalmente atribuída; e a proibição não se restringiria apenas à publicação de uma cópia da carta, ou parte do diário, mas se estenderia também à publicação de seus conteúdos. O que é protegido, portanto? Certamente não é o ato intelectual de registrar o fato de o marido não 
ter jantado com a esposa, mas o fato em si. Não se trata do produto intelectual, mas de sua ocorrência doméstica"38.

Em suma, a lei de copyright poderia proteger a publicação de uma carta, mas não a divulgação dos fatos privados contidos nela. O que ocorreria então, se alguém recebesse uma carta sobre a qual nenhum direito de propriedade intelectual tenha sido registrado? Ela poderia publicá-la, ou divulgar seu conteúdo? A resposta, para os juristas, é negativa: "A obrigação é simplesmente observar o direito legal do remetente, (...) seja ele chamado seu direito de propriedade dos conteúdos da carta, ou seu direito de privacidade.

Desse modo, o direito de privacidade emerge com um sentido adicional em relação à ideia de propriedade simples, e que reside, fundamentalmente, no fato de que suas prerrogativas "não emergem do contrato ou de confiança especial, mas são direitos contra o mundo" (grifo meu). A partir deles, reconhece-se a existência de uma esfera que é propriedade do indivíduo, mas cujo sentido principal é o de estar em oposição ao mundo, e que, portanto, deve ser "deixada em paz".

Vemos, portanto, que a privacidade emerge com dois sentidos fundamentais: como a propriedade tradicional do indivíduo sobre a casa e a personalidade, e como esfera de existência contra o mundo. A insistência dos autores em mostrar a diferença entre ambos e estabelecer o último como a singularidade da privacidade mostra claramente que a casa já não era mais entendida como simples propriedade e que sua existência agora adquiria um novo sentido, separado da esfera da reprodução material e do espaço público em geral.

\footnotetext{
38 1890, p.3-4, tradução minha.
} 
Esse sentido da privacidade, como o "direito de ser deixado em paz", embora esteja enraizado no modo de vida burguês do século XIX, como veremos no segundo capítulo, tem até hoje influenciado a maior parte das teorias que procuram definir a privacidade. Em outros termos, quase todas elas são uma espécie de derivação da concepção de Warren e Brandeis. A teoria do "limite do acesso ao eu"39, por exemplo, baseia-se no princípio de que algum grau de inacessibilidade é fundamental para o pleno desenvolvimento individual, bem como no princípio de que é necessário o sigilo de determinados aspectos da vida considerados pessoais; Richard Posner (1998) por exemplo, define a privacidade como o direito individual de esconder fatos que 0 desacreditem. Ele entende a privacidade, ademais, como uma forma de racionalidade econômica, segundo a qual as pessoas esconderiam fatos verdadeiros sobre elas, mas que, de algum modo, as prejudicariam em sua vida social, profissional ou pessoal.

Irwin Altman (1977) também define a privacidade como controle seletivo de acesso ao eu, isto é, como o "controle dos limites pelos quais os homens se mostram às vezes abertos e acessíveis aos demais e outras vezes se fecham a seus semelhantes ${ }^{\prime 40}$. Esse processo será sempre dialético e envolverá a tensão entre revelar-se e ocultar-se, já que, continuamente, é preciso adaptar o nível de privacidade a momentos de abertura e visibilidade, mas também a situações em que certa opacidade e fechamento são desejáveis. Segundo o autor, essa dialética, embora variável conforme a cultura e ao longo do tempo, como um dado antropológico, seria observável em todas as sociedades.

39 Cf. Van Den Haag, E. 1983, p. 10-11. 401977, p.67. 
A maioria dos autores que se dedicaram ao tema da privacidade, principalmente os de origem norte-americana e alemã, baseiam-se na concepção de privacidade como uma "necessidade humana básica"41, seja ela de cunho psicológico ${ }^{42}$, moral ${ }^{43}$, ou antropológico ${ }^{44}$. Uma série de pesquisas procurou se apoiar numa linha argumentativa evolucionista para explicar a necessidade humana de isolamento, como fundamental para o equilíbrio das relações sociais entre os homens e para sua sobrevivência ${ }^{45}$. Para essa linha de pesquisa, a privacidade aumentaria a chance de sobrevivência, ao reduzir a competição por comida e recursos reprodutivos.

Os que entendem a privacidade como necessidade psicológica do homem acreditam que ela seja fundamental para facilitar a liberação das emoções e para "fornecer aos indivíduos a liberdade necessária para uma reflexão não-distorcida sobre o eu verdadeiro e para o comportamento e apresentação do eu autêntico" ${ }^{\text {46 }}$.

Outras teorias partem do princípio da propriedade individual sobre a personalidade e aspectos a ela relacionados. Nesse sentido, há as teorias que pregam o controle sobre a informação pessoal, a partir da consideração de que esta é propriedade de quem a originou ou uma extensão de sua personalidade e, portanto, deverá ser considerada privada ${ }^{47}$. A noção de que os indivíduos são proprietários da informação gerada sobre eles mesmos remonta a John

\footnotetext{
${ }^{41}$ Debatin, 2011, p.47

${ }^{42}$ S. Trepte e L.Reinecke, 2011 e M.Z Yao, 2011

${ }^{43}$ Debatin, 2011

${ }^{44}$ Altman, 1977

45 Halmos 1953, Klopfer and Rubenstein 1977, citados por M.Z Yao, 2011, p.119

${ }^{46}$ S.Trepte e L.Reinecke, 2011, p.67

${ }^{47}$ Cf. Westin, 1967.
} 
Locke e sua concepção de que eles possuem direitos de propriedade sobre sua própria pessoa e os frutos de seu trabalho. De acordo com o filósofo: "cada homem tem uma 'propriedade' em sua própria 'pessoa',48, logo, ao retirar algo do estado natural e misturar a isso o seu trabalho, terá então juntado algo de si próprio a esse produto, que fará dele sua propriedade.

O princípio de "pessoalidade" (personhood), por exemplo, aparece como extensão da ideia de que é privado aquilo que for relativo à personalidade, e também em uma concepção normativa de integridade da personalidade que deve ser protegida. Baseado também na concepção de Warren e Brandeis da "personalidade inviolável", Paul Freund ${ }^{49}$ criou o termo "personhood" para se referir "àqueles atributos do indivíduo que são irredutíveis em sua pessoa".

Outro modo de tentar entender a privacidade é definindo-a como condição para a intimidade. Para esse tipo de teoria, a intimidade tem importância fundamental para a criação da identidade individual e para as relações humanas. O cientista politico Robert Gerstein ${ }^{50}$, por exemplo, afirma que "as relações íntimas simplesmente não poderiam existir sem que houvesse privacidade". Jeffrey Rosen, do mesmo modo, acredita que: "Para florescerem, as relações íntimas, que dependem do verdadeiro conhecimento sobre a outra pessoa, precisam de espaço e de tempo: santuários protegidos dos olhares da multidão nos quais a abertura lenta e mútua é possível" 51 .

Embora essas definições ressaltem aspectos importantes do fenômeno em questão, ao colocar determinada ênfase sobre certos valores, a maior parte

48 Locke, 1966, p. 117-241.

49 Freund, 1975, p. 42-43

50 Gerstein, Intimacy and Privacy, 1984, p.265.

51 Rosen, 2000. 
dessas teorias incorre no mesmo problema: elas acabam essencializando uma configuração que, na verdade, é histórica. A intimidade, a autonomia do indivíduo, seu direito de estar só, sua personalidade e tantos outros princípios ligados à noção de privacidade, não são valores que devam ser protegidos por serem bons em si, mas valores ancorados em processos sociais mais amplos e que são mais ou menos valorizados conforme tais processos. Dessa forma, não se entende o valor de tais noções sem reconstruir previamente o contexto social de sua inscrição normativa, assim como a moldura ideológica que as contorna.

Assim, ao tentar definir o núcleo normativo do conceito, essas teorias fecham os olhos para o aspecto, em nossa opinião, mais importante, ou seja, de que a privacidade, antes de se constituir enquanto normatividade, diz respeito a modos de vida, a formas de ocultar determinados aspectos da existência que se transformam ao longo do tempo. Ao derivar seus sentidos da concepção original proposta em 1890, como se de lá para cá nenhuma transformação no significado do "privado" tivesse ocorrido, essas teorias são incapazes de compreender as transformações do conceito de privacidade. Perceber essas transformações só é possível, portanto, a partir do exame da configuração das fronteiras entre público e privado e das mudanças que essa dicotomia e seus limites sofrem a partir de determinados processos históricos. O sentido da privacidade, hoje, certamente não é o mesmo de quando Warren e Brandeis escreveram. Se os juristas perceberam naquela época uma mudança fundamental no significado da vida privada, é preciso levar adiante essa intenção e buscar as inflexões decisivas sem as quais não se pode compreender seu significado presente. Para isso tentaremos no próximo 
capítulo reconstituir os principais momentos dessa história. A estratégia adotada é mostrar como, em cada fase, ou "espírito do capitalismo", a relação entre vida privada e sistema irá criar uma estrutura própria para a manifestação da privacidade. 


\section{Capítulo 2 - A privacidade: da invenção burguesa ao presente}

\subsection{As origens: de um privilégio social da burguesia a um direito de todos}

O desenvolvimento histórico da sociedade é, em muitos aspectos, caracterizado pelo fato de que o que, numa era pretérita, era manifesto, entra sob a proteção do segredo; e que, inversamente, o que um dia foi secreto, não mais precisa de tal proteção, mas se revela.

Georg Simmel

Grande parte dos sentidos atualmente atribuídos à noção de "privado" não estavam presentes no início da modernidade. Comportamentos que hoje parecem naturais a um contemporâneo, tais como o encobrimento das funções corporais, da cópula e outras necessidades fisiólogicas, não o eram até meados do século XIX, por exemplo ${ }^{52}$. Até esse período, todos os membros das famílias pobres usualmente dividiam o mesmo quarto e, por exemplo, o casal não tinha como esconder dos outros o sexo e outras funções do corpo, consideradas no presente como privadas.

Uma das formas mais incipientes de privacidade adquire seus contornos durante a Reforma Protestante. Somente em solidão o indivíduo pode

${ }^{52}$ STONE, 1991. 
encontrar-se com Deus e falar diretamente a $\mathrm{Ele}^{53}$. A recomendação protestante da salvação pela fé conduz os homens a escutar suas consciências no recolhimento privado; a escuta do foro interno carece de solidão, isolamento, privacidade.

O conceito em questão adquire maior consistência com o liberalismo, o qual torna ideal normativo o cultivo da vida privada. Os liberais secularizaram o âmbito do foro interno, fazendo da privacidade uma esfera na qual o indivíduo pudesse desenvolver com plenitude suas capacidades. Para tanto, seria fundamental o distanciamento da coletividade e da instância pública representada pelo Estado. A privacidade ficaria desse modo definida como um espaço de soberania individual, fundamental para o exercício da liberdade e da formação do eu.

No entanto, a despeito do impulso liberal ao desenvolvimento da privacidade, foi apenas no século XIX, com o desenvolvimento do capitalismo industrial na Europa, que ela se estabeleceu de fato e modificou expressivamente os hábitos de vida da época. Essas mudanças foram refletidas em todas as esferas de existência: no trabalho, na vida doméstica, na casa, na rua e no espaço destinado a homens e mulheres. A ideia que hoje fazemos de privacidade é, portanto, herdeira daquela engendrada pela sociedade burguesa florescente. Como disse Peter Gay ${ }^{54}$, "nenhuma outra classe, em nenhum outro momento, foi mais fervorosamente devotada às aparências, à família e a privacidade do que a burguesia do século XIX. Nenhuma outra classe criou proteções tão vastas ao self". Podemos incluir no

\footnotetext{
${ }^{53}$ Cf. WEBER, Max. 2004.

${ }^{54}$ GAY, 1999, p.403.
} 
rol de devoções burguesas o apego, também, pela casa, cuja caracterização como "lar", proteção para a vida privada, passou a refletir claramente os anseios burgueses por privacidade.

O modo de vida burguês, com sua devoção à família, ao lar e a uma intimidade secretamente construída e preservada, deram origem a essa "descoberta maravilhosa" que era a privacidade, "necessidade para os ricos" e "aspiração para os pobres" ".5 . Uma vida criada aparte do olhar dos outros começou a materializar-se em vários âmbitos: na sociabilidade restrita entre os membros da família, na maior intimidade entre os casais, na criação de espaços para vivenciar a solidão, no uso de objetos que estimulavam o fortalecimento da individualidade, tais como diários, álbuns de fotos, espelhos e mais uma série de outros suportes para o desejo de afirmação da identidade individual. A descoberta da privacidade foi fundamental para que os burgueses pudessem desenvolver uma relação consigo próprios e assim, para que cultivassem uma nova esfera da vida: a subjetividade.

O desejo de criar um espaço para ocultar determinados aspectos da existência, porém, também foi a razão principal para que, tão prestimosos do segredo, os burgueses, por seu forte moralismo, se tornassem especialistas na arte das reticências, dos rodeios e do silêncio diante de fatos da vida, considerados embaraçosos.

A casa burguesa, âmbito da família, erigida como o grande templo da privacidade, constituía o principal abrigo para a prática do segredo. Em um período no qual o interesse próprio passava a guiar a busca pela realização 
pessoal e a ideia de concorrência e competição ganhavam corpo, tornava-se especialmente importante a existência de um território resguardado dos perigos de "fora". Conforme nota Peter Gay, "os observadores do século XIX tinham pouca dúvida acerca da natureza agressiva do homem"56. Havia forte crença, principalmente para os cristãos, na perversidade da natureza humana ambiciosa, sensual, combativa e agressiva - e, portanto, não se deveria poupar esforços para domá-la. A casa seria o único lugar onde o indivíduo encontraria conforto e alívio para proteger-se do perigo das agressões externas representadas pelos outros - e internas - representadas por suas próprias fraquezas e limitações.

Ao recordar da carta escrita por Freud a sua esposa Martha Bernays, em que o primeiro elaborava uma detalhada lista sobre todos os ítens que julgava essenciais para seu "pequeno mundo de felicidade", Gay conclui que, para ele, o lar burguês "seria um porto seguro, um armazém de memórias, uma fonte de prazer"57. A casa permitia que "por trás da vida exterior de cada homem, da vida que ele leva em público", houvesse "uma outra vida que ele leva sozinho, e que carrega consigo fora do alcance das pessoas com quem convive. Dos nossos vizinhos vemos apenas uma face, assim como vemos apenas uma face da lua"58.

Entretanto, nem sempre fora assim. Como vimos no texto de Warren e Brandeis escrito em 1890, a necessidade de estabelecer a privacidade como um direito específico estava relacionada a transformações importantes no

\footnotetext{
${ }^{56}$ Idem, p.3.

57 Ibid., p.317.

${ }^{58}$ Trecho escrito por Walter Bagehot em 1853 e citado por GAY, 1999, p. 319.
} 
modo de vida da época, as quais, certamente, apontam para o desenvolvimento dessa esfera de existência que descrevemos aqui. Uma das principais mudanças que enunciam o novo modo de vida diz respeito à função da casa. Antes do capitalismo industrial, as casas não possuíam como função exclusiva o abrigo e a proteção da família. Ao contrário,

“(...) muitas casas consistiam meramente num grande espaço multi-funcional. Entre a burguesia incipiente, as casas eram primeiramente um local de trabalho, uma fábrica com um espaço ao fundo ou acima para comer e dormir. Eram lugares agitados e muito povoados, com frequência habitados por uma ou mais famílias grandes" ${ }^{\text {". }}$.

Até meados do século dezoito, a família funcionava como o núcleo da indústria doméstica, e todos os seus membros, incluindo mulheres e crianças, tomavam parte no processo produtivo. A integração da família ao processo produtivo impedia que houvesse separação entre a esfera de vida do trabalho e outra esfera doméstica, privada ${ }^{60}$.
"A casa de uma família proprietária de imóvel na Inglaterra do século XVII era um complexo empreendimento econômico que incluía não apenas as crianças e os parentes, mas os servos, aprendizes e trabalhadores de diferentes classes sociais. Em seu comando, encontrava-se o paterfamilias que trabalhava junto com a esposa, os filhos e os empregados. Ele era o único responsável pelo bem-estar econômico e espiritual de sua família e representava a suposta unidade e independência dela. As relações domésticas da casa constituíam uma parte muito clara das relações de produção no capitalismo nascente" ${ }^{61}$
O capitalismo nascente distinguia-se de outros modos de vida pela atribuição de valor moral acentuado ao trabalho realizado para a produção de

\footnotetext{
${ }^{59}$ Solove, 2002, p.1138-9- tradução minha

${ }^{60}$ Philippe Ariès, 1993, p.4.

${ }^{61}$ Zarestky, 1976, p.39, tradução minha.
} 
mercadorias. Essa nova valorização da produção, baseada no princípio da propriedade privada e na ideia protestante do "chamado", fez com que valor correlato fosse atribuído à família, já que ela era a unidade básica da produção ${ }^{62}$. Além disso, principalmente entre os puritanos, ela possuía papel importante para o aprofundamento da auto-consciência e da percepção de uma vida interior, psíquica, necessária para a relação com Deus.

A tendência geral do desenvolvimento capitalista, de "socializar os processos de produção de mercadorias", isto é, remover o trabalho do âmbito dos esforços privados de famílias ou vilas e centralizá-lo nas unidades corporativas de larga escala ${ }^{63}$, junto à valorização da família como um âmbito relacionado ao sagrado, foram fundamentais para a consolidação da divisão entre público e privado que separava a esfera do trabalho produtivo da vida familiar.

A introdução das máquinas no processo produtivo coroava essa divisão, impelindo os trabalhadores a se identificarem com a regularidade invariável dos autômatos complexos, requerindo um processo de trabalho racionalizado, coordenado e sincronizado, distante das perturbações da vida comunitária, tais como as responsabilidades da vida familiar, as relações pessoais e os sentimentos. Além disso, com o uso de máquinas, a produtividade do trabalho pôde ser significativamente aumentada. "Parece evidente, afirma Marx, "que um trabalhador que executa toda sua vida uma única e mesma operação simples transforma todo o seu corpo em órgão automático e unilateral dessa operação e que ela the demande menos tempo que ao artesão que executa

\footnotetext{
${ }^{62}$ Zaretsky, 1976, p.28.

63 idem, p.29
} 
toda uma série de operações alternadamente. (...) Assim, em relação ao ofício artesanal autônomo, se produz mais em menos tempo, ou se se quiser, a força produtiva do trabalho é acrescida" 64 .

Em 1897, um francês chamado E.Levasseur notou que os donos das fábricas acreditavam que essas mudanças beneficiavam os trabalhadores, tanto como vendedores de mão de obra, pois o salário havia aumentado, quanto como consumidores de mercadorias, porque seriam capazes de comprar mais bens com o mesma quantidade de dinheiro. Porém, os trabalhadores não concordavam com essa suposição, pois achavam que as máquinas os exauriam, por demandar atenção contínua e enervante, e por degradar os homens transformando-os em máquinas ${ }^{65}$.

O trabalho tornou-se cada vez mais especializado e subdividido durante o século XIX e, em muitas indústrias, várias habilidades não eram mais necessárias. O artesão que sabia fazer um sapato do começo ao fim foi substituído por trabalhadores menos qualificados, cada qual com número menor de tarefas. Coletivamente, faziam-se mais sapatos, mas a satisfação com o trabalho diminuiu substancialmente conforme ele se tornou uma dura rotina $^{66}$. Victor Kiernan, no prefácio ao livro de Engels ${ }^{67}$, lembra o veredito de um relatório médico sobre as condições de saúde dos trabalhadores industriais do período, concluindo que seu vigor físico e mental estava sendo solapado. $\mathrm{E}$ acrescenta que "o tédio da rotina na fábrica, que exigia apenas a atenção suficiente para evitar que o trabalhador pensasse em qualquer outra coisa

64 Marx, Karl, 1985, p.269, citado por Nascimento, R. (2006), p.96.

65 E. Levasseur, 1897, citado por Nye, D.E. (1999), p.132.

66 Nye, D.E, 1999, p. 134.

67 1987, p.6. 
(como o famoso sapateiro era aparentemente capaz de fazer), deve ter tido um efeito negativo para a mente",68.

Conforme a produção passou a ser centralizada no espaço das fábricas, a vida doméstica também adquiriu novos sentidos. A piora significativa das condições de trabalho nas fábricas reforçou a idealização da família e da vida privada em geral como "a tent pitch'd in a world not right" ${ }^{69}$, ou como um abrigo privado da dureza do mundo do trabalho na fábrica. Essa idealização elevou a família à condição de um lugar sagrado, o domínio do espírito em oposição ao domínio material da atividade produtiva e, portanto, o local privilegiado para o cultivo do eu e da intimidade, tão estimado pelos burgueses. Assim, ideais de autoconhecimento e de autorrealização começaram a tomar corpo na esfera privada, e foram estendidos, inclusive, aos trabalhadores, que também passaram a buscar sua felicidade nas relações pessoais e domésticas, fora da esfera do trabalho ou do mundo público.

Nesse período as prósperas famílias burguesas já podiam liberar a esposa de qualquer trabalho fora de casa, mudança que não foi de todo bemvinda, como lembra Peter $\mathrm{Gay}^{70}$. Muitas mulheres, agora responsáveis integralmente pela criação dos filhos, manutenção do lar, preparo das refeições, cuidados de saúde, reprodução e etc, descobriram que cuidar da casa é tão cansativo e bem menos interessante do que dividir os afazeres de uma pequena loja ou de uma pequena indústria caseira ${ }^{71}$. $O$ trabalho feminino

68 Idem.

69 "uma tenda de proteção armada em um mundo ameaçador" (tradução minha). Coventry Patmore, The Angel in the House, citado por Zarestsky, 1976, p.51.

70 Gay, P. 1999, p.317.

71 Idem. 
passou a ser privado, invisível e socialmente desvalorizado, de acordo com as feministas, mas indispensável, como parte integral da economia capitalista, como aponta Zaretsky. A divisão sexual do trabalho, que iria separar homens e mulheres em posições diferentes no processo produtivo, também passou a ser refletida na crença em esferas de existência separadas para ambos os sexos. Esta ideia esteve presente na obra de diversos filósofos da época, como Hegel, por exemplo, o qual, em sua Filosofia do Direito, afirma que, "o círculo apropriado para a mulher é a família e a vida privada"72, já que, como ele conclui, "não pode ser dito que alguma mulher tenha tido alguma importância na história do mundo"73.

A fortificação vitoriana dos muros entre o público e o privado calcava-se, fundamentalmente, na associação do feminino à esfera privada, o que contribuiu, com efeito, para a construção da imagem da mulher como o "sexo misterioso", "frágil", "indomado", que carece dos esforços masculinos de pais e maridos para ser domesticado ${ }^{74}$. Quando contratadas pelas fábricas (por serem menos propensas a se filiarem a sindicatos, já que estes, além de realizarem reuniões em horários inconvenientes para as mulheres - como sábado à noite, em bares -, também compartilhavam a ideia largamente disseminada de que seu lugar era em casa), recebiam metade do salário dos homens e eram consideradas mão-de-obra menos qualificada ${ }^{75}$.

\footnotetext{
${ }^{72}$ Citado por Peter Gay, 1994, p.292 trad. minha.

${ }^{73}$ Idem.

74 Ibid., p.289

${ }^{75}$ NYE, David E., p.137.
} 
Do mesmo modo que a repressão do feminino ${ }^{76}$, a hipocrisia em relação às emoções e à sexualidade ${ }^{77}$, que parecia também reinar em outros domínios da sociedade, constitui elemento marcante da educação dos sentidos na sociedade vitoriana, cujo modo de funcionamento deu origem à histeria como patologia psíquica. Esse período, caracterizado por Boltanski e Chiapello ${ }^{78}$ como a primeira fase do capitalismo, tem como centro o burguês empreendedor, aventureiro e disposto a assumir riscos, mas, ao mesmo tempo, poupador, controlado, perito nas habilidades do cálculo e da racionalização das ações, combinadas com a "importância atribuída à família, à linhagem, ao patrimômio, à castidade das moças" ${ }^{\prime 79}$, bem como às relações paternalistas com empregados e à "caridade para aliviar o sofrimento dos pobres" ${ }^{\prime 20}$. Esse amálgama de disposições aparentemente contraditórias de que fala o autor "sede de lucro e moralismo, avareza e caridade, cientificismo e tradicionalismo familiar"81 - constitui a base para uma das principais críticas ao espírito burguês da época: a hipocrisia nele presente.

A autocrítica e o exame constante de si e de suas faltas absorveram as maiores mentes da época e povoaram as obras de muitos autores que se entregaram à enervante "prática burguesa de fazer uma coisa e dizer outra", ou procuraram criticá-la, como Freud, Flaubert, Baudelaire, Whitman, Nietzsche e

\footnotetext{
76 "It was tough, by concealing woman behind the veils of her enigmatic nature, men could evade the unpalatable truth that their mother was a sexual being. Proclaiming a woman to be a dark problem, men were happily dispensed from searching for a solution" (Idem)

77 Gay, 1984, p. 405

78 Boltansk e Chiapello, 2009.

79 Idem, p.49

${ }^{80}$ Ibidem, p.50.

${ }^{81}$ Ibid.
} 
tantos outros fizeram ${ }^{82}$. Engels, por exemplo, no livro $A$ Situação da Classe Operária na Inglaterra ${ }^{83}$, mostrou como os ricos nada queriam saber sobre as misérias pelas quais eram largamente responsáveis; o próprio arranjo físico das cidades industriais inglesas permitia que pudessem andar pelas cidades sem tomar conhecimento da pobreza a que boa parte da população estava submetida.

O pavor de revelar determinados assuntos, protegidos pelos eufemismos e reticências, criou um arranjo no qual determinados assuntos deveriam permanecer intocados, escondidos e, muitas vezes, reprimidos. Esses assuntos diziam respeito a aspectos da realidade que não se desejava trazer à lume, como a sexualidade, a situação das mulheres e a exploração dos trabalhadores, principalmente. Tais temas terminavam circunscritos à esfera privada. No nível subjetivo, eram suprimidos pela ação da culpa e dos constrangimentos morais. Na esfera da vida material, o seu resguardo cabia à família e à casa, cuja arquitetura acabava adaptando-se ao desejo de privacidade dos moradores, ao menos, dos burgueses.

Nas classes populares, contudo, a constituição da privacidade como resultado de um processo de individualização era comprometida pela própria estrutura das habitações, que dificultava qualquer separação entre público e privado. Carentes de isolamento, tanto em relação à rua, quanto em relação aos co-habitantes, os trabalhadores espremiam-se em cortiços e casas abarrotadas de gente, em meio à privação, à falta de higiene e doenças, com pouco ou nenhum espaço para a solidão, sem qualquer possibiidade de

\footnotetext{
${ }^{82}$ Gay, 1994, p.407

${ }^{83}$ Engels, 1987.
} 
alguma privacidade. Entretanto, no fim do século XIX já era possível vislumbrar algumas mudanças importantes nessa condição, refletidas, no plano material, pelo desejo de uma casa própria para abrigar a família nuclear dos trabalhadores, e, no plano subjetivo, pelo desejo de privacidade agora também presente no interior da classe trabalhadora.

O processo de transformação da "casa promíscua" em "casa moderna" ${ }^{84}$ foi bastante semelhante em âmbito brasileiro, conforme nota Fausto ${ }^{85}$. Por volta de 1860 , as primeiras levas de imigrantes que chegavam em terras paulistas, assim como os trabalhadores europeus, amontoavam-se em cortiços, em condições precárias e insalubres ${ }^{86}$, como revela a descrição de um desses moradores:

(...) Os fundos do cortiço davam para a rua 25 de Março, onde, naquele tempo, se encontrava o mercado de verduras, de miúdos e de peixe. (...) Da entrada partia um corredor para o qual davam alguns quartos; em cada quarto morava uma família; o quarto era muitas vezes dividido por uma cortina que separava os homens das mulheres da família. O corredor levava a um quarto, o maior da casa, em que cada qual tinha seu fogareiro e onde havia um lavatório de uso comum, tanto para a limpeza pessoal como para a cozinha. As mulheres cozinhavam nesse aposento, mas cada família comia no seu próprio quarto. As condições higiênicas eram péssimas, usavam-se vasos cujo conteúdo era despejado num gabinete sanitário construído no quintal. Tomar um banho era difícil, porque todos tinham de se arrumar para tomar no quarto (C.Castaldi, "O ajustamento italiano à comunidade paulistana", citado por Fausto, 1998, p.3940)

\footnotetext{
${ }^{84}$ Philip Ariès, História social da criança e da família, p.265, citado por Fausto, p.37.

${ }^{85}$ A História da Vida Privada no Brasil: contrastes da intimidade contemporânea, vol. 4. 1998, p.37.

${ }^{86} \mathrm{Em}$ condições ainda piores viviam os negros recém-libertos, os caboclos e sertanejos. Como mostra Wissenbach (1998), as moradias, "no geral choças, construídas de pau a pique" na zona rural; "um quadrilátero de quato a cinco metros de largura e dois metros de altura sob a caída do teto; as paredes em talos de bambu recobertos de terra vermelha seca", "nenhum móvel no interior" (p.64).
} 
Entretanto, conforme foram se acomodando e encontrando melhores condições de trabalho, por vezes até enriquecendo, os imigrantes podiam também adquirir moradias melhores, "passando pelas construções de qualidade intermediária - a casa geminada, a isolada de ambos os lados, ostentando um jardim e um quintal nos fundos - (...) ao extremo oposto do cortiço, ou seja, o palacete mandado construir pelo imigrante enriquecido" 87

A melhora nas condições de vida, ao menos para essa classe, permitia que Ihes fosse possível copiar o estilo de vida das classes abastadas locais. Isto incluía a imitação da disposição da casa, com mais espaços privados e também a adoção dos valores burgueses. Desse modo, a casa tornou-se, também para os trabalhadores, "o domínio privado por excelência, fundamento material da família e pilar da ordem social", como afirma a historiadora Michelle Perrot $^{88}$.

Os direitos individuais, defendidos pela burguesia contra os privilégios dos direitos de nascença, desempenharam papel fundamental na criação dos valores do individualismo em suas diversas formas, incluindo a privacidade. A sociedade do liberalismo, ou do "individualismo quantitativo", nos termos de Simmel, era uma sociedade de indivíduos que, agindo em seu próprio interesse, avançavam no propósito social: indivíduos competindo uns com os outros, regulados pela lei do livre mercado. No século XIX, o conflito entre indivíduo e sociedade adquire um novo sentido.

\footnotetext{
${ }^{87}$ Fausto, 1998, p.42.

${ }^{88}$ Perrot, M. "Maneiras de Morar", citado por Fausto, p.40.
} 
De um lado aparece a "sociedade" - a economia capitalista, o Estado, o inflexível núcleo social que não tem espaço para o indivíduo; de outro, a identidade pessoal, não mais definida por seu lugar na divisão social do trabalho. De um lado, portanto, há o mundo social objetivo, percebido primeiro como "maquinaria" ou "indústria"; depois como "sociedade" ao longo do século XIX, como "grandes corporações" e "burocracia" no XX, e finalmente, como como "tecnologia" ou simplesmente "vida" (...). Em oposição a esse mundo duro que nenhum indivíduo pode afetar, surge o mundo moderno da subjetividade ${ }^{89}$.

A defesa romântica do artista e do gênio no individualismo do século XIX é um grande exemplo da oposição entre indivíduo e sociedade. Ao longo de todo o período, houve a exaltação de figuras que viviam afastadas da sociedade e da proletarização, por conta de sua unicidade pessoal: o herói, o virtuoso, o místico, o viajante mundial, o judeu errante, o aventureiro e o dândi ${ }^{90}$, encorajando a ideia de que a única forma de escapar à mediocridade da rotina e do trabalho seria pela via da unicidade e das qualidades especiais individuais.

As duas figuras características do trabalho na época - a dona de casa e o proletário - apareceriam como reflexo da divisão social entre sentimentos (amor, felicidade e realização pessoais), atribuídos ao feminino, e produção econômica, identificada ao masculino. Porém, para os que foram transformados em proletários, a identidade individual não se poderia mais realizar por meio do trabalho ou da posse da propriedade; logo, os indivíduos teriam de buscar por si mesmos sua valorização. Nesse processo, a família tornou-se a principal esfera da sociedade da qual os indivíduos, ao menos os trabalhadores, eram "proprietários". Dentro dela, uma nova esfera de atividade

\footnotetext{
${ }^{89}$ Zaretsky, 1976, p.57, tradução e grifo meus.

${ }^{90}$ Idem, p.59.
} 
social tomou forma: a vida pessoal. Assim, a ideologia vitoriana do século XIX da família como repositório dos "valores humanos" e como um "abrigo utópico" passou a ser compartilhada por burgueses e trabalhadores (Zaretsky, 1976, p.61).

A vivência familiar como promotora de uma felicidade compensatória à arduidade do processo de trabalho sob hegemonia da grande indústria propagou-se durante muito tempo como ideologia eficaz. Marx mostra como a passagem da manufatura para a grande indústria consolidou a posição central do trabalho na vida cotidiana, de modo que o trabalhador não apenas passou a organizar todo o seu tempo em função do trabalho, mas este também passou a orientar o próprio sentido da vida cotidiana ${ }^{91}$. O tempo de repouso tornou-se um tempo destinado à recuperação das energias para o trabalho, o tempo de formação intelectual passou a ser dedicado à melhor qualificação na indústria e de modo semelhante em diversas esferas da vida ${ }^{92}$. Em suma, o sentido do tempo livre tornou-se o próprio trabalho. Portanto, o tempo vivido na esfera familiar, embora apareça como um momento destinado ao puro deleite da intimidade, não deixa de ser orientado à produtividade, ao menos indiretamente.

Sob essas condições, emergiu a família do século $\mathrm{XX}$, aparentemente separada do processo produtivo e da esfera econômica, e bastião da vida pessoal, onde a subjetividade, a felicidade e a realização poderiam florescer longe dos percalços e durezas do mundo do trabalho. Em outras palavras, a disseminação da ideia de que o trabalhador estaria livre uma vez que pusesse

\footnotetext{
${ }^{91}$ Marx, Karl. O Capital, vol. 1., 1982.

92 Nascimento, Rodnei. 2006, p.101.
} 
os pés fora da fábrica (e dentro de casa), contribuiu para que homens e mulheres olhassem para si mesmos em busca de sentido e propósito para suas vidas.

Essa ideia, fortalecida pela experiência no mundo do consumo, foi herdada e passada adiante pela família do século XX, como ilustra o exemplo da mãe do escritor norte-americano Jonathan Franzen, uma dona de casa que, sem fé num paraíso prometido pela religião e sem acreditar na prosperidade de um sistema econômico que havia produzido a Grande Depressão de 1929, sintetizou os anseios de sua juventude vivida na primeira metade do século $X X$ da seguinte forma: "Eu acredito fortemente na vida familiar. Sinto que o lar é a base da verdadeira felicidade na América - muito mais do que a igreja ou a escola poderiam um dia ser"93.

\subsection{A privacidade no segundo espírito do capitalismo: da santidade do lar ao mercado}

Se a fase que dominou o capitalismo no século XIX e no primeiro terço do XX foi marcada pela poupança e sua moral de comedimento, controle, disciplina, restrição, labor, regularidade, perseverança e estabilidade ${ }^{94}$, na segunda, "eis um tipo de sociedade que substitui a coerção pela sedução, o dever pelo hedonismo, a popupança pelo dispêndio, o recalque pela liberação e as promessas do futuro pelo presente ${ }^{95}$. Paradoxalmente, a figura emblemática dessa nova fase não é mais o capitalista aventureiro do primeiro

\footnotetext{
${ }^{93}$ Franzen,J. 2006, p.14, tradução minha.

${ }^{94}$ Bolstanski e Chiapello, p.189.

95 Lipovetsky (2006), p.35.
} 
espírito, movido pela ambição e pela inventividade. Ao contrário, o personagem-chave é agora o empregado, o burocrata que se submente às regras da organização e o diretor (ou dirigente assalariado) - e não mais o burguês proprietário ${ }^{96}$. A passagem do mundo da pequena propriedade e dos pequenos empresários para uma sociedade caracterizada pela propriedade concentrada e pelos empregados assalariados trouxe substantivas transformações ao modo de vida da época. Para entender esse espírito é fundamental perceber de que modo forças aparentemente opostas o hedonismo consumista, de um lado, e a contenção burocrática, do outro - se relacionam.

Essa é a época do surgimento das grandes organizações, das sociedades anônimas, da planificação, do taylorismo, da gestão empresarial racional. O desenvolvimento do racionalismo econômico faz com que a organização se sobreponha ao indivíduo: o sistema adquire vida própria e funciona de modo quase autônomo em relação aos homens ${ }^{97}$. Nas palavras de Sombart,

"À medida que se fez sentir a necessidade de racionalizar a economia, o descobrimento dos meios destinados a satisfazer essa necessidade converteu-se em uma ocupação independente, principal ou acessória, para grande número de pessoas. Milhares e milhares de indivíduos, desde os professores que ensinam os princípios da economia em nossas escolas de comércio, até os inumeráveis revisores de contabilidade, calculistas, fabricantes de toda classe de máquinas automáticas, consagram hoje toda sua atividade e engenho a buscar e aplicar os melhores métodos para assegurar a boa marcha dos negócios. Os empregados e operários das grandes empresas são alentados com benefícios para que contribuam à

\footnotetext{
${ }^{96}$ Lopez-Ruiz, Osvaldo., 2004.

${ }^{97}$ Idem.
} 
melhoria do racionalismo econômico. (...) Para todos aqueles que se consagram a esta atividade, o aperfeiçoamento do racionalismo econômico converte-se em uma tarefa vital, em um fim em si mesmo. Produz-se aqui o mesmo fenômeno que temos observado na evolução da técnica: olvida-se o fim e aperfeiçoa-se por aperfeiçoar; o homem com seus interesses e suas necessidades vitais é deixado de lado para não pensar mais do que no sistema. (...) O sistema está no coração da empresa capitalista como um espírito invisível: é o que conta, o que leva os livros, o que calcula, o que determina os salários, o que poupa, o que registra, etc. Opõe-se ao sujeito econômico com força autônoma, formula-lhe exigências e o coage. Jamais se apazigua, sempre aumenta e se aperfeiçoa. Vive uma vida própria ${ }^{98}$.

O homem, cuja função no trabalho passou a ser resumida como "aquele que dá corda ao relógio"99, ou que simplesmente presta serviços a uma grande organização, vê ainda mais motivos do que seu predecessor para procurar a auto-realização na esfera privada junto à família. É por isso que, nesse modelo, a separação iniciada na fase anterior, entre a pessoa do trabalhador e a força de trabalho que ele vende no mercado - ou entre a vida privada e profissional é ainda mais marcante. Qualquer sinal de mistura entre esses domínios passa a ser fortemente criticada: patrões que favorecem parentes, ou levar em conta a vida privada, a moralidade ou a visão política do funcionário na hora da contratação $^{100}$.

O modelo de "boa vida" para esse personagem é o de "uma vida sossegada, preferentemente num lugar agradável fora da cidade, com uma mulher e três filhos; um automóvel, ou talvez dois, e um lugar de

\footnotetext{
${ }^{98}$ Sombart, 1953, p. 328-329, citado por Lopez-Ruiz, 2004, p.75.

99 Idem, p.77.

${ }^{100}$ Boltanski e Chiapello, p.192-3.
} 
veraneio num lago ou frente ao mar e, posteriormente, um bom colégio para que os filhos se eduquem"101. De acordo com Sombart, esse homem pouco fala em dinheiro, mas refere-se, o tempo todo, à sua "vida"102. Por este termo entenda-se sua vida suburbana, "na qual o trabalho só ocupe uma parte" 103

A geração de burocratas e empregados apáticos e sem paixão pelo trabalho, que entregava toda sua energia ao desfrute da vida suburbana despertava preocupação nos pensadores da época. Acerca disso, escreveu Wright Mills sobre a sociedade norte-americana em 1951:

"O evangelho do trabalho tem sido um aspecto essencial da tradição histórica americana, da imagem que ela faz de si mesma, e da imagem que 0 resto do mundo tem da América. A crise e o declínio desse evangelho têm uma significação profunda. (...) a agressividade e 0 entusiasmo que marcaram as outras gerações está desaparecendo... Quando o trabalho não é mais do que trabalho, uma atividade realizada apenas por motivos de subsistência, o espírito que incentivou essa nação para sua grandeza atual já desapareceu. Uma apatia ameaçadora oculta o descontentamento e a impaciência dos quadros dirigentes de amanhã"104.

Essa nova classe "não-burguesa", como chama o autor, não havia sido contagiada pela antiga ética do trabalho de sua antecessora. $\mathrm{O}$ trabalho para ela, separou-se das outras atividades da vida: todas as satisfações que a vida Ihes proporciona ocorrem fora dos limites do trabalho; trabalho e vida estão profundamente separados, dirá W. Mills, e isso complica

\footnotetext{
${ }^{101}$ Lopez-Ruiz, 2004, p.137.

102 Sombart, p.70, citado por Lopez-Ruiz, p.137.

103 Lopez-Ruiz, p.137.

${ }^{104}$ Mills, W. White Collar: The American Middle Classes, 1969, p. 237-238.
} 
grandemente a tarefa dos que dirigem e administram os processos produtivos.

A vida dos empregados passou a ser preenchida com o desfrute das benesses do consumo de massa florescente. Na medida em que o salário havia tomado o lugar da propriedade produtiva como base econômica da família, a "propriedade privada" foi redefinida entre os trabalhadores para referir-se a mercadorias: comida, roupas, artigos domésticos e, mais tarde, à casa.

Acostumados ao discurso da sobriedade, do trabalho duro e da disciplina, os empregados tiveram de ser (re)educados para o novo discurso centrado na apreciação de uma vida hedonista, com novos desejos e necessidades. A disseminação de novas mídias, como o cinema, o rádio, a imprensa tablóide e as revistas de circulação em massa foram fudamentais para a divulgação dos novos valores e formas de comportamento. A propaganda também teve papel central para incentivar os indivíduos a participarem do consumo de mercadorias antes restrito às classes altas, seduzidos a partir do oferecimento de imagens de juventude, beleza e luxúria, associadas à liberação de desejos longamente reprimidos.

Segundo Stuart Ewen ${ }^{105}$, os executivos de negócios do ramo da propaganda nos EUA dos anos 1920, conscientes da necessidade de os novos mercados absorverem a crescente capacidade da produção em massa, fizeram uma campanha agressiva para estimular novas necessidades, desejos e hábitos de compra. A propaganda auxiliou sobretudo a corrupção dos velhos

${ }^{105}$ Ewen, 1976, p. 33, citado por Featherstone, 1991, p.174. 
valores, contribuindo para o descrédito das noções puritanas de frugalidade, paciência, abstinência e moderação ${ }^{106}$. O consumo nasceu, assim, como uma "máquina de tentações, um assalto à disciplina do eu, que prometia estimular os sentidos e trazer ao alcance do trabalhador comum uma vida extraordinária e confortável, capaz de diminuir sua fadiga" ${ }^{107}$. Transportados à uma dimensão onírica por meio das imagens publicitárias, os trabalhadores deparavam-se com propostas, feitas pelo comércio, de estilos de vida, modelos de bom gosto e de uma vida excitante.

Assim, cada vez mais aspectos da vida privada foram sendo subsumidos à lógica mercantil: lazer e tempo livre, hobbies e outras experiências tornaramse cada vez mais dependentes do mercado em expansão. Esse é um aspecto fundamental para se compreender a nova relação entre vida privada e sistema no segundo espírito do capitalismo. Se em ambas as fases a vida privada está intimamente ligada ao mundo do trabalho e é orientada por ele, a relação irá se construir de modo diferente em cada momento. A comparação feita por LopezRuiz sintetiza muito bem essa diferença: ele lembra do exemplo dado por Weber ${ }^{108}$ do velho norte-americano que, apesar de rico e de idade avançada, encontrava-se inquieto e sem poder desfrutar da família por querer ampliar ainda mais a fachada de sua loja. O dia de domingo, para ele, não era mais do que uma fastidiosa pausa para retomar a luta para que sua loja fosse a maior da cidade ${ }^{109}$. O executivo sênior, em contraposição, é movido pelos interesses da organização em que trabalha e os sonhos que o animam são "mais bons

\footnotetext{
${ }^{106}$ Featherstone, 1991, p.174.

${ }^{107}$ Ehrenberg, 1995, p.59

${ }^{108}$ Weber,M. A Ética Protestante e o Espírito do Capitalismo, p.194.

${ }^{109}$ Lopez-Ruiz, 2004, p.144
} 
filés nas refeições, outros hotéis confortáveis para experimentar e mais vôos em primeira classe"110. No primeiro espírito, a oposição entre trabalho e família consagrava à esta um lugar de descanso, recuperação de forças e desfrute da intimidade. No segundo, já há claramente uma presença maior das forças econômicas externas na esfera privada: embora o burocrata pareça ser movido pela convivência familiar e pouca paixão demonstre pelo trabalho, há nesse estágio uma presença muito maior da esfera econômica em sua intimidade, que se revela na centralidade que as mercadorias adquirem em sua vida. Desse modo, embora a marcante separação entre trabalho e vida familiar pudesse nos levar para a direção oposta, isto é, a de que a esfera econômica estaria completamente ausente da esfera privada no segundo espírito do capitalismo, não devemos nos deixar confundir: se no primeiro espírito a privacidade protege a esfera privada da intromissão das forças externas, incluindo as econômicas, no segundo, estas começam gradualmente a empurrar as barreiras da privacidade.

Entretanto, se a emergente sociedade de consumo via na esfera privada um rico mercado fundamental para seu crescimento, a separação estrita entre vida pessoal e trabalho não vinha sendo benéfica para o capital. O trabalho não poderia ser mais apenas um meio de subsistência; era preciso que fosse mobilizado novamente o gosto pelo risco, pela aventura, a ambição e a devoção ao trabalho. A partir dessa percepção, os especialistas do mundo dos negócios passaram a empreender uma busca por novas justificações que apresentassem uma motivação para o esforço cotidiano no trabalho assim

\footnotetext{
${ }^{110}$ Idem.
} 
como um sentido para este ${ }^{111}$. Como observa Wright Mills, "para obter e aumentar a boa disposição para o trabalho é necessário criar uma nova ética que dê ao trabalhador outro incentivo além do econômico".

Assim começaram os estudos de "relações humanas na indústria", que procuravam uma forma de integrar a vida privada ao trabalho. $\mathrm{O}$ sucesso das políticas distributivas do Estado e o fortalecimento dos sindicatos forçavam respostas do mundo corporativo às ameaças representadas pela resistência ao trabalho. A retórica das emoções, com o vocabulário benigno da comunicação, da empatia e da cooperação, apareceu como a resposta mais adequada a esse desafio, na medida em que não só neutralizava as tensões, como era capaz de engajar novamente o trabalhador por inteiro- de corpo e alma aos seus processos. Veremos como, no terceiro espírito do capitalismo, esse engajamento será um aspecto determinante para entender a aproximação inédita entre vida privada e economia.

\subsection{Espaços de transição e fronteiras em movimento: aproximações entre o público e o privado}

A transição para o terceiro espírito do capitalismo e para um novo desenho da relação entre público e privado não se deu sem que houvesse espaços de transição entre um tipo de vivência e outro. O bairro, por exemplo, que sempre fora visto como um espaço "semi-público", no qual as pessoas se encontravam, se conheciam, mas conseguiam manter certo nível de resguardo das informações íntimas, começa adquirir um novo significado a partir das

${ }^{111}$ Lopez-Ruiz, 2004, p.151. 
inovações arquitetônicas modernas. Com o aumento das distâncias criadas pelos seus grandes prédios e conjuntos habitacionais, o convívio com os vizinhos passou a ser escasso e o bairro tornou-se um local de pessoas estranhas. As "lojinhas" são substituídas por grandes centros comerciais nos quais as pessoas chegam de carro; do mesmo modo passam pelo drive-thru em busca de uma refeição rápida. Os bares, redutos tradicionais da sociabilidade masculina, já não dispõem de freguesia constante - são locais de passagem $^{112}$.

Nos subúrbios, as distâncias são marcadas de modo análogo: o morador da casa com o jardim frontal gosta de determinar energicamente a fronteira que o separa dos outros e da rua com as cercas $^{113}$. Os evetuais diálogos, com carteiros, vizinhos e passantes se dão por sobre elas. A própria rua torna-se um espaço domesticado, com pouca circulação de pessoas.

Se esse distancianamento proporcionou a libertação das amarras da censura, da maledicência e da vigilância alheias, com ele os habitantes dos grandes centros urbanos eliminaram progressivamente o aspecto pessoal das zonas de transição. Mesmo nos espaços de convívio mais próximo, como mercados, cafés e bares do bairro, a sociabilidade torna-se mais distante, por um lado, e menos intrusiva, por outro.

No ambiente profissional, entretanto, as mudanças dão-se no sentido oposto: se os grandes prédios isolavam os habitantes da cidade e solapavam as relações pessoais nos bairros, em âmbito profissional as relações começaram a tornar-se cada vez mais "pessoalizadas". "Ilhas de sociabilidade

\footnotetext{
112 Prost, Antoine, 1992, p.123.

113 Idem, p.27.
} 
informal" surgem nas cantinas e cafés das empresas, onde se permite que haja conversas longe dos ouvidos dos superiores ${ }^{114}$ e a sociabilidade com os colegas de trabalho começa a tornar-se mais próxima, mediante tentativas de restabelecer relações pessoais dentro do ambiente rígido das organizações.

Comentam-se incidentes de trabalho, e os boatos correm soltos. Desenvolvese uma socabilidade profissional em torno das atividades do comitê da empresa: organização de viagens, temporadas de esqui, concursos de pesca, sessões de ginástica, noites esportivas, teatrais ou musicais, cursos de inglês, compras em conjunto de vinhos ou brinquedos etc. (...) Mas também são abordados temas mais pessoais: as férias, os filhos, as preocupações da vida doméstica. E aqui o convívio encontra um novo campo: como no bairro de outrora, ele permite que a pessoa fale discretamente de si a interlocutores que não foram escolhidos nem rejeitados. Estatuto incerto e equilíbrio frágil das relações de uma vizinhança que é aceita, e que hoje podem ser mais frequentes entre as amizades de trabalho do que nas lojas do bairro ${ }^{115}$.

Desse modo, a vida privada, expulsa do universo coletivo e público do trabalho, torna a ingressar nele de maneira discreta e gradativa. Além da maior sociabilidade entre colegas, como uma tentativa de estabelecer relações mais próximas em meio à frieza e impessoalidade que reinavam nas organizações, as próprias organizações começam a perceber que deveriam incorporar os aspectos pessoais da vida rechaçados pela extrema racionalização taylorista. Nos anos 1950 e 1960, começaram a se tornar populares as teorias da "gestão emocional"116, que pregavam uma aproximação entre líderes e subordinados, em vez da gestão fria e distante típica das grandes organizações. Essas teorias baseavam-se em estudos, como os de Elton Mayo na General Eletric, que

\footnotetext{
114 Ibid., p.128.

${ }^{115}$ Ibidem, p.128-9.

116 Illouz, 2007.
} 
mostravam que a maior atenção dada aos sentimentos dos trabalhadores poderia aumentar significativamente sua produtividade ${ }^{117}$. Com efeito, a retórica das emoções, baseada no repertório da terapia, tornou-se presente tanto nas estratégias produtivas das empresas, como na gestão dos conflitos e das relações entre os empregados. ${ }^{118}$ É importante ressaltar essa passagem, pois ela registra o preciso momento em que se percebeu, pela primeira vez, que a vida pessoal poderia dar bons frutos quando incorporada devidamente ao processo produtivo.

Desse modo, é possível perceber nesse momento de transição para um novo espírito que a separação da existência em dois domínios nitidamente distintos começa a se enfraquecer: apesar dos cercamentos que isolaram a vida privada nas cidades, o ingresso da vida pessoal nos espaços profissionais nesse momento é o prelúdio daquilo que veremos se concretizar no presente: a obsolescência da privacidade.

\subsection{A vida privada no capitalismo conexionista}

Após 1968, a contestação ao modelo burocrático adquiriu maior força e os jovens passaram a recusar com veemência as hierarquias, os trabalhos padronizados, as rotinas rígidas, a inautenticidade, a falta de criatividade e autonomia e a tecnocratização. Em 1975, uma pesquisa da SOFRES $^{119}$ na França mostrava que, para os jovens, a primeira qualidade de um trabalho era

\footnotetext{
117 Illouz, 2007, p.15

118 Idem.

${ }^{119}$ Société française d'enquêtes par sondages.
} 
a de estar adaptado a seus gostos pessoais ${ }^{120}$. No mesmo ano, outra pesquisa conduzida pelo sociólogo Bernard Galambaud constatou a enorme importância que $\circ$ ambiente de trabalho tinha para os jovens parisienses. Descobriu também que "um bom ambiente de trabalho" significava a presença de relações pessoais autênticas ${ }^{121}$.

A integração da linguagem terapêutica ao discurso corporativo foi fundamental nesse quadro de demandas, pois foi capaz de captar as transformações no ambiente de trabalho, neutralizando conflitos de classe ao transpô-los para a linguagem benigna das emoções e da personalidade ${ }^{122}$. Para os trabalhadores, essa linguagem tornou-se atraente por soar mais democrática, na medida em que colocava o sucesso mais nas mãos das qualidades pessoais, do que em privilégios sociais inatos. A hierarquia dentro da empresa não deixou de existir; no entanto, tornou-se um conceito arcaico ante os valores da "igualdade" e da "cooperação", o novo foco das teorias da gestão empresarial. Do mesmo modo, a empatia - capacidade de identificar-se com, de colocar-se no lugar do outro - passou a ser um prerrequisito para o bom relacionamento e a boa comunicação no ambiente de trabalho ${ }^{123}$.

Junto à contestação das hierarquias no mundo do trabalho veio o desafio às formas disciplinares e de autoridade gerais. Estudantes contestam a autoridade pedagógica de professores, filhos desafiam a autoridade dos pais, mulheres protestam contra o mando dos homens e trabalhadores refutam a liderança os sindicatos. Autonomia e autenticidade são os valores-chave

\footnotetext{
${ }^{120}$ Prost, A. 1992, p.129.

${ }^{121}$ Idem, p.193.

122 Illouz, p.17.

${ }^{123}$ Idem, p.20.
} 
dessas demandas, que, no campo do trabalho, foram traduzidas por uma só palavra: flexibilidade ${ }^{124}$. Assim, os funcionários podem fazer o próprio horário, ser avaliados por seus méritos próprios e sua performance individual, bem como ter seus recursos internos valorizados pelos contratadores. No entanto, além do esgarçamento das formas de solidariedade no trabalho, esses deslocamentos corresponderam ao desenvolvimento de formas de emprego precárias (temporário, contrato por tempo determinado, tempo parcial ou variável) ${ }^{125}$.

Esses trabalhadores, porém, já não encontraram o mesmo respaldo nas organizações trabalhistas, tampouco, viram em seu horizonte respostas políticas consistentes para suas condições. Se o individualismo dos anos 80 foi marcado pela negação do espírito público e a valorização das iniciativas da sociedade civil, um de seus resultados também foi a crise de representação politica.

Essa crise foi interpretada de diversas formas e marcou o diagnóstico da época. Para Alain Ehrenberg, a ausência da política será preenchida pela empresa como modelo e solução para todos os problemas, incluindo aqueles que, antes, encontravam tradução em linguagem política ${ }^{126}$. Com a falência progressiva do Estado de bem-estar-social e as promessas não-cumpridas de pleno emprego e bons salários para todos, as frustrações e os sofrimentos, tanto públicos, quanto privados, passaram a ser codificados por uma linguagem psíquica. No centro desse modelo há o homem que faz do próprio eu um

\footnotetext{
${ }^{124}$ Boltanski e Chiapello, p.248

125 Idem.

${ }^{126}$ Ehrenberg, A. 1995.
} 
projeto e que toma as rédeas do seu desenvolvimento para não ficar de fora das relações sociais. $O$ empreendedor, símbolo supremo dessa figuração, põe em cena um modo de ação para todos: cada um, tanto no topo, como nos baixos escalões da hierarquia social, parte para a dupla conquista do sucesso social e da identidade pessoal, conquistanto um "si mesmo" em progresso. A partir de então, o indivíduo empreendedor de si mesmo passa a enxergar a si próprio como um objeto de trabalho em constante processo de aperfeiçoamento $^{127}$.

Contudo, a transformação de todos os sucesso e fracassos da vida em responsabilidades individuais parecem significar pressões excessivas a serem transferidas aos ombros do indivíduo. Os quadros depressivos e de dependência de substâncias surgem como sintomas, mas, para além dos quadros patológicos, um dos resultados da chamada crise política do pós-80 foi, segundo Ehrenberg, a transferência do campo de batalha para dentro do homem: resta ao indivíduo lidar com as questões que a política não consegue mais responder. Assiste-se, portanto, a um duplo processo de extensão e inflação da responsabilidade e da subjetividade: é com essa dupla dinâmica que se depara o indivíduo incerto, simultaneamente mais solicitado e mais ávido de reconhecimento ${ }^{128}$. Esse indivíduo busca a solução de seus problemas pessoais de modo bastante peculiar: as revistas e emissões de rádio e televisão tornam-se canais de expressão de conflitos e demandas de um sujeito que procura tornar visível seu sofrimento e que tenta construir no espaço coletivo da mídia uma compreensão do próprio eu.

\footnotetext{
${ }^{127}$ Ehrenberg, 1995, p.14-15.

${ }^{128}$ Idem, p.p 23-4
} 
Como lembra Bauman ${ }^{129}$, o primeiro registro desse tipo de comportamento parece ter sido na década de 1980, na França, quando uma mulher declarou em um programa televisivo que seu marido sofria de ejaculação precoce e, por essa razão, ela nunca havia experimentado um orgasmo em sua vida de casada. A revelação, na época, causou grande impacto; entretanto, gradualmente a tentativa de solucionar conflitos privados em público passa a tornar-se corriqueira: é lá, junto à multidão solidária (em geral formada por uma platéia), que se buscarão conselhos, opiniões e orientações para as aflições íntimas do dia a dia.

Para Ehrenberg, a TV apenas tornou visível uma crise que já estava disseminada em toda a sociedade e que foi responsável pela "recomposição do

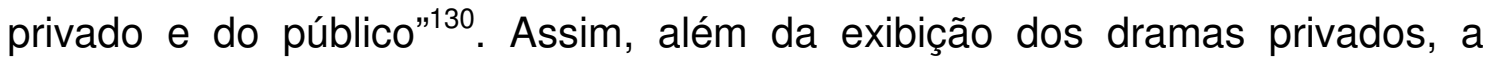
popularidade dos "Psy-shows" mostram como a TV se torna a via privilegiada para comunicar, de modo privado, as questões pessoais no espaço público ${ }^{131}$. Nesse sentido, o declínio da cultura disciplinar e hierárquica que deixou 0 indivíduo a sós com a tarefa de compreender a si próprio e resolver os seus problemas criou um novo arranjo entre público e privado que privilegia os espaços da mídia como arenas nas quais ele pode falar, ser ouvido e aconselhado. $\mathrm{O}$ autor conclui que essa busca constitui menos uma mostra do egoísmo do indivíduo que se volta para si mesmo e esquece a política do que a procura de um canal relacional, de um vínculo com o outro, que foi esgarçado com a reestruturação do capitalismo.

\footnotetext{
${ }^{129}$ Bauman, 2010.

${ }^{130}$ Ehrenberg, 1995, p.170

131 Idem, grifo meu.
} 
Nesse sentido, Ehrengerg se distancia de Christopher Lasch, que também ofereceu uma interpretação bastante interessante e contundente sobre o novo arranjo entre público e privado que tem início no fim da década de 1970 - início dos anos 1980. Ambos concordam que a origem do fenômeno poderia ser atribuida à crise política que consuma a decadência do Welfare State na Europa e a ascensão do neoliberalismo, posto em prática pelos governos de Ronald Reagan nos EUA e Margareth Thatcher na Inglaterra. Entretanto, enquanto para Lasch o resultado da crise política seria o triunfo do narcisismo, isto é, uma forma de auto-absorção para qual o mundo é apenas uma projeção do próprio vazio interior do eu ${ }^{132}$, para Ehrenberg a exposição de si nos canais midiáticos seria uma forma de procurar refazer vínculos sociais: a partir da exibição dos problemas pessoais, o indivíduo atrairia a empatia alheia e se sentiria menos solitário e desamparado diante dos novos desafios postos pela nova ordem.

Ambos autores, todavia, adotam o mesmo ponto de partida para seu diagnóstico, a saber, o de que o recuo das formas tradicionais hierárquicas representadas pelas autoridades da família e das instituições em geral teria sido tido papel fundamental para o disparo da crise. No livro Haven in a Heartless World - The Family Besieged (publicado em 1977) ${ }^{133}$, Lasch propõe que o excesso de permissividade do final do século $X X$, em contraposição à estrutura repressora do desejo anterior, típica das sociedades disciplinares, teria dado origem à ideologia da gratificação imediata dos impulsos,

\footnotetext{
${ }^{132}$ A tese da cultura do narcisismo será retomada no próximo capítulo, no qual será explorada com maior detalhamento.

${ }^{133}$ Esse livro foi traduzido para o português, em 1991, pela Editora Paz e Terra, com o título: "Refúgio num mundo sem coração. A família: santuário ou instituição sitiada?”.
} 
acompanhada pela ansiedade intolerável que continuamente frustraria essa demanda. O aparente triunfo do princípio do prazer teria ocasionado também, além da perda de credibilidade das figuras de autoridade, tais como pais e professores, o próprio estado depressivo e novas formas de dominação, mais pautadas pela chantagem e pela intimidação, do que pelas antigas formas de repreensão disciplinares. Os pais, assumindo o papel de "friendly helpers" (assim como as outras figuras de autoridade) e evitando conflitos a todo custo, passaram a procurar novas respostas para os problemas com a prole, tais como ajuda psiquiátrica e psicológica, ou outro tipo de ajuda profissional. $\mathrm{O}$ resultado da "separação entre amor e disciplina" na família seria, portanto,

\begin{abstract}
"o desenvolvimento de traços de personalidade mais compatíveis com regimes totalitários do que com a democracia: um forte vínculo com o grupo de pares; um forte medo da solidão; alienação em relação ao passado (...); uma forte preocupação com a 'autenticidade' pessoal nas relações, não mediada por formas convencionais de cortesia e etiqueta ou mesmo respeito pela individualidade dos outros; e uma falta de introspecção e de uma vida interna bem desenvolvida ${ }^{134}$.
\end{abstract}

No livro subsequente, A Cultura do Narcisismo, de 1979, Lasch dá sequência a esse argumento, propondo que a busca incessante pela autorrealização, tanto no trabalho, quanto em outras esferas da vida, direcionou os indivíduos para si próprios, para seu próprio bem-estar físico e emocional. Esse desinteresse, já captado pelos pais da democracia, encontraria todo seu vigor no decorrer dos processos que conduziram à suposta retirada do indivíduo do cenário público. Se ao longo do século $X X$ essa decadência foi amainada pelo vigor das revoluções e, principalmente, dos

${ }^{134}$ Lasch, 1977, p. XVI. 
movimentos sociais e políticos dos anos 1960, nos anos 1980 ela voltou com toda força, em uma "era de esperanças em declínio", permeada por um sentimento de pessimismo captado por diversos autores ${ }^{135}$. Nos EUA, a derrota no Vietnam, a estagnação econômica e a exaustão dos recursos naturais criaram, como percebeu Lasch, um mal-estar sentido em todo o Ocidente e traduzido por ele como "crise política do capitalismo", em que o liberalismo teria perdido a capacidade de explicar os eventos do mundo e nada teria sido posto em seu lugar ${ }^{136}$. Um dos sintomas dessa crise seria a progressiva retirada dos indivíduos para a esfera privada e à difusão do narcisismo como estratégia de sobrevivência preponderante diante do vazio deixado pela política.

Crítica parecida é empreendida pelo sociólogo Richard Sennett no livro "O Declínio do Homem Público: as Tiranias da Intimidade", no qual defende que, na sociedade contemporânea, as questões públicas não suscitariam mais paixão, que só seria despertada quando o problema fosse tratado como questão pessoal ${ }^{137}$. A "superposição do imaginário privado sobre o imaginário público" ocorrida ao longo do século XIX teria resultado em uma confusão comportamental e ideológica entre os dois âmbitos ${ }^{138}$. Para o autor, o caráter repressivo da sociedade vitoriana, apesar de condenável, era mais compreensível do que o arranjo da sociedade íntima, na medida em que o retraimento dos sentimentos representava um modo de manter certo grau de invulnerabilidade. Nesse contexto, a exposição do vigor da personalidade era reservada para arenas públicas com essa função, tais como o teatro. A

\footnotetext{
${ }^{135}$ Tais como Richard Sennett, R. Bellah (Habits of the Heart), Lipovetsky (A Era do Vazio) e Lasch (A Cultura do Narcisismo).

${ }^{136}$ Lasch, 1979, p.11

${ }^{137}$ Sennett, 1977, p.19.

${ }^{138}$ Idem, p.41.
} 
teatralidade como um todo, no sentido de preservação das convenções e regras de comportamento que marcam distância estaria relacionada a uma vida pública vigorosa. $\mathrm{Na}$ sociedade íntima, ao contrário, são desprezadas quaisquer formas de teatralidade por seu caráter supostamente inautêntico e não espontâneo que serviria para esconder a verdade do eu ${ }^{139}$. Segundo essa tese, quando a intimidade se sobrepõe aos valores coletivos, a principal forma de reconhecimento é pautada por qualidades pessoais, e o sentimento torna-se a principal forma de identificação. Disso resulta a decadência da esfera pública, minada por uma realidade governada por normas narcísicas:

"O narcisismo é mobilizado nas relações sociais por uma cultura desprovida da crença na vida pública e governada pelo sentimento íntimo como medida da realidade. Quando assuntos como classe, etnia, e exercício do poder falham em se conformar a essa medida, quando eles falham em constituir um espelho, deixam de despertar paixão ou preocupação"140.

Embora muito semelhante ao diagnóstico de Lasch acerca do narcisimo como patologia da cultura, para este, o problema com essa abordagem seria a tendência presente na análise de Sennett em "exaltar o liberalismo burguês como a única forma civilizada de vida política e a 'civilidade' burguesa como a única forma não corrompida de conversação pública"141. Além disso, "a grande ânsia de Sennett em restaurar uma distinção entre vida pública e privada, sobretudo, ignora os meios pelos quais são elas sempre interligadas" ${ }^{\text {142 }}$. Nesse sentido, Sennett confunde, segundo Lasch, causa e consequência, já que, "ao

\footnotetext{
${ }^{139}$ Diagnóstico no mesmo sentido foi feito por Jurgen Habermas, para quem a esfera pública burguesa teve seu potencial crítico e emacipador comprometido, em razão da crescente interpenetração entre o público e o privado, bem como das transformações engendradas pelo desenvolvimento da comunicação de massa. Cf. HABERMAS, 2003.

${ }^{140}$ Sennett, 1977,p.326, trad. minha.

141 Lasch, 1979, p.52.

${ }^{142}$ Idem, p.53.
} 
culpar o mal-estar contemporâneo pela invasão da esfera pública cometida pela ideologia da intimidade", ele não percebe que "o culto da intimidade origina-se não da afirmação da personalidade, mas de seu colapso", e que "nossa sociedade, longe de favorecer a vida privada à custa da vida pública, tornou cada vez mais difíceis de ser conquistadas amizades profundas e duradouras, casos de amor e casamentos" ${ }^{\text {"143. }}$.

Desse modo, além da decadência da esfera pública, a própria esfera privada estaria em declínio, e o narcisismo seria uma estratégia de sobrevivência ao colapso de ambas. Lasch imaginava que esse cenário levaria não a um recuo político em absoluto, mas a uma revolta política geral que emergiria dos escombros do capitalismo e do liberalismo falido. Embora o desfecho não tenha sido esse - e muitos elementos vislumbrados por ele como detonadores da crise tenham sido acirrados no presente sem que a revolta ocorresse - o valor de sua análise é preservado como um importante diagnóstico de época. E essa é a forma como pretendemos tomá-lo aqui.

No lugar da revolta houve, ao contrário, certo otimismo na virada para o século XXI acerca de um novo sopro de vigor do capitalismo, representado pelo surgimento dos negócios ligados às emergentes tecnologias da informação e comunicação. Esse foi o momento de uma reestruturação geral do capitalismo "em torno dos mercados financeiros e dos movimentos de fusão-aquisição das multinacionais" ${ }^{\text {"144 }}$ e também de forte incentivo ao aumento da flexibilização do trabalho. Esse otimismo, refletido na chamada "bolha da Internet" ou das "empresas ponto com", foi fugaz (a bolha estourou em 2000 e

\footnotetext{
143 Ibid., p.53.

${ }^{144}$ Boltanski e Chiapello, p. 22.
} 
levou muitas empresas à falência); entretanto, a Internet, as novas formas de sociabilidade e os novos negócios haviam chegado "para ficar" e transformar irreversivelmente a economia, o trabalho, a cultura e a vida social.

Desse modo, a vida privada, cujo desvelamento já seguia uma tendência clara desde os anos 1980, adquiriu ainda maior vigor com os novos canais de sociabilidade oferecidos pela Internet. Nesse sentido, o diagnóstico da decadência da esfera pública pareceu vir a calhar e foi bastante reiterado para tentar explicar as novas formas de exposição da vida íntima nos espaços virtuais. Porém, diante de cenário modificado pela introdução da nova tecnologia e da reestruturação do capitalismo em torno dos mercados financeiros, as velhas explicações começaram a parecer inadequadas e insuficientes. No próximo capítulo procuraremos examinar como o fenômeno é visto contemporaneamente, bem como propor uma nova forma de entendê-lo, tendo por base sua relação com as novas demandas do capitalismo. 


\title{
Capítulo 3 - A exposição de si online: reconhecimento, gozo, busca de autenticidade e adequação aos valores do capitalismo conexionista
}

\begin{abstract}
"Em tempos de redes sociais, em que a conquista só vale se for fotografada afinal, de que adianta eu conquistar se ninguém tiver a oportunidade de sentir inveja de mim? -, a intimidade parece ter ficado em segundo plano. Um fondue regado a vinho numa noite fria não tem graça se as bocas lambuzadas de queijo não virarem uma foto de Instagram, uma cervejinha num bar não é tão divertida se não se puder fazer check-in no Foursquare, um passeio ao ar livre num dia de sol não tem tanto valor se não rolar pelo menos um post no Facebook esfregando para toda uma timeline a sua felicidade" ${ }^{\text {"145. }}$.
\end{abstract}

A essa altura do texto, o leitor já deve estar convencido dos inúmeros tipos de ameaças à privacidade postas pela interação com a Internet. Porém, como explicar que, apesar dos riscos e das ameaças cada vez mais flagrantes, a exposição permaneça e, em vez de diminuir, tenda a crescer, dia após dia, nos meandros da rede? Pesquisa conduzida por Stutzman, Gross e Acquisti (2012), entre os anos de 2005 e 2011, com usuários do Facebook, para entender as mudanças de comportamento em relação à privacidade nesse período, descobriu que, nos primórdios da rede havia uma preocupação maior com a privacidade, e os usuários procuravam limitar progressivamente os dados publicamente compartilhados com "estranhos" (usuários de Facebook não pertencentes à mesma rede). No fim do período pesquisado, a tendência

\footnotetext{
${ }^{145}$ Grotti, Bruna. Sobre Relacionamentos Na Era do Exibicionismo - Amor de Verdade Precisa de Provas Públicas? Blog Casal Sem Vergonha. 20/07/2013.
} 
inverteu-se e os usuários passaram a compartilhar publicamente cada vez mais informações privadas, isto é, tornando-as visíveis para qualquer usuário daquela rede social. Com isso, as revelações para os "ouvintes silenciosos" também aumentaram: o próprio Facebook, outros aplicativos e os anunciantes passaram a ter amplo acesso a informações voluntariamente reveladas pelos "facebookers".

Supomos que essa maior exposição venha acompanhada de algum tipo de satisfação, afinal, o que motivaria esse comportamento? Entretanto, a maior abertura da vida privada parece ter sido acompanhada por alguns dissabores. Em entrevistas com estudantes da Universidade de Indiana, a pesquisadora Ilana Gershon (2011) descobriu que eles consideravam o Facebook uma ameaça a seus relacionamentos, por transformá-los em pessoas ansiosas, ciumentas, controladoras e invejosas, características que não desejavam possuir. Muitos passaram a ter problemas em suas relações, pondo fim a namoros e amizades por conta dos sentimentos negativos adquiridos no decorrer das interações virtuais. Ao tomar consciência disso, alguns viam como saída desativar a conta na rede social.

Porém, apesar de parecer fácil, a saída da rede social poderia criar outros problemas para os desistentes. Abandonar uma rede social, criada por vezes com muita dedicação e esforço, significa, sobretudo, abrir mão de conexões, algo que, como se sabe, tornou-se a menina-dos-olhos da fase em que se encontra o capitalismo atualmente. Um estudo recente feito pelo Pew Research Center mostrou que os jovens se sentem desgastados com 0 excesso de informações compartilhadas, mas eles continuam a utilizar a rede 
porque ela é crucial para sua vida social ${ }^{146}$. Assim, suspeitamos que desativar o perfil da rede social não seria suficiente para que os sentimentos negativos também fossem desligados e a "pressão" sentida pelos jovens desaparecesse. Para Gershon, os sentimentos relatados pelos estudantes eram sintomas da transposição dos princípios neoliberais aos selves dos jovens. O Facebook os encoraja a se apresentarem como um "conjunto flexível" de habilidades, traços úteis e gostos (de consumo) que precisam ser constantemente aprimorados" (p.867), bem como a se engajarem em relações do tipo "neoliberal", conexões fracas e funcionais a serem ampliadas constantemente.

Assim como o mercado, o Facebook oferece muita informação, mas de modo incompleto. Desse modo, os entrevistados da pesquisa afirmavam ter dificuldade para interpretar as relações estabelecidas por seus companheiros por meio de uma comunicação sem contexto, permeada pelo excesso e pela incompletude informacional simultaneamente. A isto, somava-se a pressão sentida para desempenhar um "self neoliberal", isto é, para gerenciar o perfil como um conjunto flexível de habilidades e gostos que precisam de cuidado e melhoramento contínuos ${ }^{147}$. Em outras palavras, o "eu" do perfil é administrado como se fosse um negócio, de modo a estar pronto a se aliar e competir com outros selves estruturados da mesma forma. Essas alianças são sentidas como arriscadas e necessárias e também obedecem a um critério quantitativo. Desse ponto de vista, quanto mais qualidades o 'eu' apresentar, melhor; e quanto mais conexões tiver, também melhor, pois significa que há mais capital social em jogo.

\footnotetext{
${ }^{146}$ MORAIS, Betsy. "How a Relationship Dies on Facebook". The New Yorker. 13/09/2013.

${ }^{147}$ Gershon, 2011, p 867.
} 
A própria Internet, nesse sentido, não escapa à lógica neoliberal. Citando Jean Dean, a autora lembra que a lógica a mover a rede é quantitativa: a do maior número de acessos a uma página e do maior número de amigos numa rede social. Preocupações com a duração e a profundidade das relações tornaram-se problemas de baby-boomers presos ao passado ${ }^{148}$.

No entanto, o resultado do desempenho do "self neoliberal", conforme a pesquisa de Gershon, era a ansiedade e a solução encontrada, deixar o Facebook. Uma de suas entrevistadas afirmou: "Você tem de apresentar a foto perfeita no perfil, que deve ser atualizada pelo menos uma vez em poucos meses. Se você não o fizer, você é um loser"149. Outra entrevistada deixava claro como se sentia competitiva em relação a uma garota de quem suspeitava estar paquerando seu namorado: "Eu tenho mais amigos do que ela no Facebook, mais amigos que ativamente escrevem na minha página e mais fotos do que ela, então sou uma cyber-persona mais popular, embora, na verdade, eu seja uma eremita. Moro sozinha e tenho um cachorro. Não saio, de fato, com essas pessoas. Mas parece que saio"150.

A exposição de si, quando mal-sucedida, pode causar dois tipos de problemas: os mais imediatos, como brigas com namorados, com amigos, incidentes de difamação e até perda de emprego, como no caso "Tam Pratinho" e muitos outros relatados no capítulo sobre difamação; e os mais sutis, como dificultar o acesso a determinados bens simbólicos e negar ao sujeito o reconhecimento do outro.

\footnotetext{
${ }^{148}$ Gershon, p.875, citando Dean, 2009, p.17.

149 Idem, p.877.

150 Ibid, p.878.
} 
Certo grau de transparência parece ser fundamental para as interações sociais e para qualquer tipo de comunicação, como afirma Georg Simmel:

Para o bem da interação e da coesão social, o indivíduo deve saber certas coisas sobre o outro. Este tampouco tem o direito de se opor a esse conhecimento, a partir de um ponto de vista moral, exigindo a discrição do primeiro: ele não pode exigir a posse sem perturbações de seu ser e sua consciência, já que tal discrição pode comprometer os interesses da sociedade. (1950, p.323, tradução minha).

A transmissão de informações sobre si, suas ideias e sentimentos é necessária para criar proximidade social e para que relações de confiança se deem. Nas sociedades modernas, Simmel identificou diferentes padrões de abertura nas relações: entre conhecidos, desconhecidos, amigos e amantes, naturalmente o grau de exposição irá variar.

Mas o que ocorre quando a exposição de si é cada vez mais intensa e as formas de segredo parecem sofrer um recuo significativo? A tentativa de estabelecer diferentes graus de abertura foi perturbada pelo surgimento da sociabilidade online. A abundância de informações sobre as pessoas, que flutua sem o trilho de um contexto para guiar a interpretação e da possiblidade de ter o fluxo controlado por aqueles a quem a informação diz respeito, é o ponto de partida para a maioria dos conflitos que cercam a privacidade online, incluindo as relações amorosas, como os exemplos de Gershon e os nossos próprios mostram.

Mas se a exposição gera problemas e sentimentos negativos, por que continua a ocorrer, volto a perguntar? Bastaria desativar o perfil do Facebook para que os problemas fossem resolvidos? Para evitar os dissabores da exposição excessiva e da falta de privacidade online, alguns autores sugerem 
uma "ética do auto-controle"151. Segundo essa abordagem, todos os usuários deveriam partir do teste de universalização kantiano e perguntarem-se: "ao postar informação, posso, ao mesmo tempo, desejar que essa informação se torne conhecida, não apenas por meus amigos, mas pelo mundo todo?"152. Não é necessário um olhar mais atento para perceber que a ética do auto-controle, tipo ideal da ascese protestante que guardava afinidades essenciais com 0 capitalismo nascente, não parece fazer muito sentido para uma sociedade mais pautada pela ética do consumo e do incentivo à satisfação dos desejos.

Como disseram Boltanski e Chiapello acerca do capitalismo, para trabalhadores e capitalistas viverem em um sistema absurdo, que aos primeiros subtrai o produto do trabalho e relega à subordinação, e aos segundos submete a um processo infindável, insaciável e abstrato, é fundamental que haja justificações ideológicas de engajamento. De modo análogo, para que o usuário das redes sociais continue a se expor, ainda que como resultado possa ter problemas pessoais e sentimentos negativos, é preciso que haja também algum recurso bastante poderoso que motive a adesão a esse tipo de prática.

Já se tornou parte do discurso corrente a ideia de que as pessoas abrem mão de sua privacidade por desconhecimento das consequências que a exposição geraria. No entanto, embora isso possa ocorrer, não está entre as razões fundamentais. Uma pesquisa conduzida por Alessandro Acquisti e Ralph Gross ${ }^{153}$ com usuários universitários do Facebook mostrou que os mais preocupados com a privacidade online tendiam a se expor mais do que os que

\footnotetext{
${ }^{151}$ Debatin, 2011, p.57.

${ }^{152}$ Idem, p.58.

153 "Imagined Communities: Awareness, Information Sharing, and Privacy on the Facebook". Privacy Enhancing Technologies Workshop (PET), 2006.
} 
revelavam menos preocupação com o assunto. Os autores detectaram pouca ou nenhuma relação entre as atitudes de proteção à privacidade relatadas pelos participantes e suas propensões a publicar informação pessoal online. Mesmo entre os estudantes mais preocupados com a sua privacidade, cerca de $40 \%$ revelavam os horários de suas aulas na rede, $22 \%$, o endereço de suas casas e $16 \%$ publicavam ambas as informações. Isso mostra que, mesmo conscientes acerca dos perigos relativos à exposição de si na Internet, os jovens não deixam de fazê-lo.

Como explicar essa contradição? Motivações muito fortes e diversas parecem estar em jogo para que o desejo de se expor seja maior do que a preocupação em proteger informações pessoais. Nos próximos itens, iremos examinar as explicações possíveis à tendência de expor a vida pessoal nos ambientes online.

\subsection{A busca por autenticidade}

Para alguns estudiosos ${ }^{154}$, a busca por autenticidade constitui um valorchave na orientação das atitudes de auto-exposição que se revelam cada vez mais presentes, principalmente nos domínios virtuais. As redes sociais ofereceriam muitas oportunidades para a auto-expressão e o estabelecimento de conexões, criando um espaço para que os usuários mostrem as qualidades que os tornam supostamente especiais. Expor a vida privada significa, nesse sentido, criar um retrato autêntico de si e, mais importante ainda, obter reconhecimento por esse retrato. Em outras palavras, ao falar de si nas redes 
sociais, o indivíduo deseja ser considerado como único, especial em suas particularidades, de forma a lembrar os anseios do indivíduo romântico qualitativo retratado por Georg Simmel.

Esse argumento pode soar um tanto anacrônico à primeira vista, já que a demanda por autenticidade parece estar presente na vida do indivíduo ocidental desde os primeiros estágios do processo de individualização. Se afirmamos que a auto-exposição é, hoje, um fenômeno significativo, assumimos que houve uma época em que isto não ocorria, isto é, em que a intimidade estava separada da esfera pública e protegida pela privacidade. Como vimos no capítulo anterior, há muitas evidências históricas que, de fato, confirmam essa observação, mostrando que na sociedade burguesa do século XIX, os assuntos pessoais eram protegidos por uma barreira de segredo. Entretanto, esta também foi uma cultura que deu origem ao individualismo "qualitativo", que assitiu ao surgimento da psicanálise, que refinou as formas de confissão das faltas pessoais e encorajou a reflexão sobre si. Para esse individualismo, a autenticidade foi um valor fundamental, cuja base era a demanda de especificidade do indivíduo, em oposição ao individualismo abstrato do século anterior ${ }^{155}$. Como disse Goethe nas Viagens à Itália, sintetizando o espírito da época, "a tarefa de todo homem é fazer algo extraordinariamente bem, como nenhum outro homem ao seu redor pode fazer"156. A partir de um substrato humano comum, o indivíduo emergia como

\footnotetext{
${ }^{155}$ Sintetizado na seguinte frase de Fichte, de acordo com Simmel: "A rational being must simply be an individual but precisely, not this or that particular individual'. Wolf, K.1950, p.80. ${ }^{156}$ Idem.
} 
um ser absolutamente único. A percepção dessa unicidade e sua realização deveriam ser, com efeito, um dever moral ${ }^{157}$.

Assim, quando se fala em busca por autenticidade, não se faz referência a um fenômeno novo, ao menos em sua essência. De que modo, então, é possível explicar a auto-exposição no presente a partir desse argumento? Os defensores dessa ideia irão dizer que tal busca agora é configurada pela apresentação do eu dramatizada e estratégica ${ }^{158}$. Tendo como ponto de partida comum a emergência da "cultura confessional"159 observada primeiramente por Michel Foucault ${ }^{160}$, esses autores acreditam que "pensar sobre si mesmo, problematizar o próprio eu e comunicar os insights a um professional" tornamse pré-condição para o reconhecimento da subjetividade e da normalidade. Esse fundamentos também dão origem à chamada "cultura da terapia", conceito que ganhou destaque nos trabalhos de Eva Illouz (2007). Essa "cultura", que incentiva a manifestação da "voz interior autêntica", encontraria na Internet o novo divã para receber as confissões, já que abriria um novo canal comunicativo, no qual se poderia encontrar o diálogo com o outro.

Entretanto, Burkart concluirá que a autenticidade buscada na presente não possui nenhuma relação com aquela do "individualismo qualitativo":

"Quando assuntos íntimos são ditos em público, eles perdem seu caráter autêntico e se transformam em uma espécie de performance teatral. O que vemos é a construção social e mediada de uma intimidade feita publicamente.

\footnotetext{
157 Ibid, p.81.

${ }^{158}$ Burkart, G. 2010, p.24.

${ }^{159}$ Ver também Johnson, P. 2010.

${ }^{160}$ Cf. Discipline and Punish: The Birth of the Prison. London, Allen Lane, 1977; e The History of Sexuality: The Will to Knowledge, vol.1., London, Penguin, 1990.
} 
Não se trata de uma apresentação sincera de um eu genuíno, mas uma ilusão de autenticidade, no máximo"161.

Nesse sentido, em sua busca por um retrato autêntico do eu, os atores criam apenas um papel, situado nas fronteiras entre o eu real e virtual; "seu objetivo, portanto, não seria mais a autenticidade, mas a atenção pública” ${ }^{\text {"162 }}$. A mudança entre a velha e a nova autenticidade residira na "transformação da busca pelo eu autêntico em busca do eu ideal"163. A conclusão do autor é a de que a cultura burguesa da autenticidade estaria em declínio e que em seu lugar teria emergido a cultura da auto-exposição, da confissão guiada pela atenção pública e das identidades pós-modernas, baseadas na indistinção entre o que é o "eu real" (o autêntico) e o "eu ideal" (aquele que se deseja exibir). Desse modo, Burkart parece deixar claro seu apego aos ideais burgueses: enquanto o sujeito burguês estava verdadeiramente comprometido com a busca de autenticidade, os sujeitos contemporâneos estariam falsamente vinculados a ela; sua real busca seria para exibir um "eu inautêntico", uma imagem baseada nos ideais da cultura contemporânea, tal qual uma propaganda de uma mercadoria que procura retratar não o que ela é de fato, mas o que o consumidor gostaria que ela fosse.

O autor parece desconsiderar que os valores de cada época só fazem sentido a partir de sua inscrição histórica. Certamente, a autenticidade almejada pelos burgueses não é a mesma do presente, mas não porque os contemporâneos estejam iludidos, e sim, porque o significado da ideia mudou ao longo do tempo. Na passagem do primeiro para o segundo espírito do

\footnotetext{
${ }^{161} 2010$, p.34.

162 Idem, p.34.

163 Ibid.
} 
capitalismo, por exemplo, o avanço da racionalização econômica praticamente neutralizou a busca por unicidade. No mundo burocratizado e pautado pelo ritmo das máquinas não há mais espaço para a manifestação da singularidade individual. Nessa fase, o indivíduo romântico cede lugar ao "homem-máquina", que se adapta aos processos organizacionais e que não tem qualquer ambição de se destacar, como mostram os trabalhos de Sombart ${ }^{164}$ e Mills $^{165}$.

Na segunda transição, esses mesmos princípios foram contestados, e a disciplina, a hierarquia, a constância e a rigidez, substituídas pela criatividade, a flexibilidade e as qualidades pessoais. É nessa fase, em que se afirma o "terceiro espírito do capitalismo", que vemos retornar a demanda pela autenticidade do indivíduo. Portanto, após aparecer como um dos temas caros ao individualismo romântico do século XIX, a autenticidade surge novamente como uma das exigências do movimento de maio de 68 , mas, dessa vez, sob novo quadro valorativo. A crítica estética, central ao movimento, conforme mostraram Boltanski e Chiapello ${ }^{166}$, opunha-se ao capitalismo como fonte de desencanto e inautenticidade dos objetos, das pessoas e dos sentimentos, e à miséria da vida cotidiana e à desumanização causada pela tecnocratização.

Na esfera do consumo, essa demanda foi incorporada a partir da criação de produtos diversificados, mais individualizados e de melhor qualidade, principalmente nos setores da moda, do lazer e dos serviços. Como lembra Wolfgang Streeck ${ }^{167}$, após a estagnação dos anos 1970, a comercialização da vida social pretendia salvar o capitalismo do espectro dos mercados saturados.

\footnotetext{
164 SOMBART, 1953.

165 MILLS, C. Wright. 1969.

${ }^{166} 2009$, p.347

${ }^{167}$ Streeck, 2012.
} 
Esse foi o período no qual as empresas aprenderam a usar a individualização a seu favor, criando possibilidades até então desconhecidas para a expressão das identidades sociais.

Desse modo, a demanda por autenticidade, distinta em cada estágio do capitalismo, ainda se faz presente, mas com outros significados. O âmbito no qual ela parece se manifestar com maior vigor é o universo do consumo, como veremos no próximo ítem, e esse aspecto, sem dúvida, aparece na autoexposição online. Entretanto, como pretendemos deixar claro ao final do capítulo, há uma busca por adequação a uma constelação valorativa maior, da qual a autenticidade é apenas uma parte.

\subsubsection{Flâneur Virtual}

Antes do Instagram, os binóculos auxiliavam os olhares curiosos e indiscretos a adentrarem as janelas dos vizinhos. Na época em que Walter Benjamin ${ }^{168}$ escreveu, a loja de departamentos era a grande atração para o flâneur. As vitrines de vidro refletiam os objetos prontos para capturarem o desejo dos passantes. Agora, eles aparecem nas telas dos celulares, oferecidos por nossos "amigos". A comparação entre o flâneur dos tempos de Benjamin e o transeunte virtual, feita por Sarah Nicole Prickett no New York Times $^{169}$, é muito apropriada: a nova Paris, a nova Manhattan do flâneur digital, agora chamado de "seguidor", é o Instagram. A partir dele, é possível visitar a intimidade dos amigos e das celebridades e invejar o seu estilo de vida. Podemos saber do novo esmalte de Gisele Bündchen, do novo vestido de

\footnotetext{
${ }^{168}$ Cf. "O Flâneur" em Benjamin, W. 1989, p.33-65.

${ }^{169}$ PRICKETT, 06/11/2013.
} 
Zooey Deschanel ou do mais novo par de Manolo Blahniks de alguma socialite internacional. Uma nova legião de international lifestyle-setters divulga seu bom-gosto em moda, decoração e gastronomia. Os pertences, cuidadosamente arranjados e fotografados em composições que mostrem o estilo e a autenticidade do proprietário, tornam-se objetos de desejo para os followers. Como Prickett observa, as legendas da foto não dizem: esses sapatos são bons, ou ficam bons em mim, mas sim: "esses sapatos ficam bons em minha vida". O fetichismo da mercadoria é pujante na afirmação e não precisa de nenhum esforço analítico para ser revelado. Não se trata apenas de fusão entre posse e proprietário, ou a indistinção entre sujeito e objeto ${ }^{170}$, mas de uma relação que permite aos objetos serem os próprios porta-vozes que falam por seus donos. Como disse Benjamin: "Aqui fala a própria mercadoria" ${ }^{171}$. Não é mais estranho ouvir alguém dizer a frase: "Eu o reconheci na rua - não por seu rosto ou seu corpo - mas por seu estilo". E por "estilo", entenda-se o conjunto de pertences que tornaram o indivíduo reconhecível. Neste caso, reconhecimento sempre limitado e efêmero; afinal, o estilo sempre pode ser copiado e, estando à venda, comprado. Assim é feito o mercado da autenticidade Para os que não podem comprar, resta invejar e contentar-se com o prazer que a imaginação da posse proporciona. Já os que podem, imitam. E ainda assim se sentem autênticos, afinal, podem sentir-se mais próximos do panteão dos especiais.

Muito antes do Instagram, já era claro o "valor de exibição" que as imagens possuíam. Na virada do século XIX para o XX, por exemplo, época da

\footnotetext{
${ }^{170}$ Cf. Sennett,1977, p.36-7.

171 1989, p.57.
} 
moda dos cartões-postais, já se via o "arrivismo agressivo" patente no exagero e euforia que revelavam as imagens, evidenciando o desejo de se associar aos símbolos da modernidade. Manaus, por exemplo, era apresentada como a "nova Paris, grande cidade moderna e vibrante da Amazônia", com a exaltação das seguintes referências: "não comia senão patê e caviar, não bebia senão cerveja alemã ou champanhe francês, não se divertia à noite senão com francesas e italianas" ${ }^{172}$.

Por trás da seleção de imagens e da escrita de si havia a tentativa, por parte de cada um dos remetentes do cartões, de alimentar uma fusão com o cenário, apresentando-se como "artífice da modernidade e beneficiário do luxo e do prazer"173. Hoje, de modo análogo, os Instagramers também procuram associar-se aos objetos que despertam entusiasmo, seja uma bela praia, uma cena familiar feliz, ou um objeto de consumo e, assim, parecerem autênticos. E, da mesma forma como, entre os postais de Gilberto Freyre, não havia sequer um que "confessasse ou insinuasse um fracasso, uma lamúria e uma decepção" ${ }^{\text {174, }}$, entre as fotos dos Instagramers também não há cenas de derrota.

Schapochnik observa que o exagero típico dos postais criava, por vezes, perfis postiços das cidades, nas quais o esplendor e a orgia do dinheiro fácil eram incompatível com a miséria dos trabalhadores anônimos. Nas redes sociais, a criação de retratos belos e favoráveis muitas vezes também está distante da realidade. No entanto, os postais, ainda que seu caráter de exagero

\footnotetext{
${ }^{172}$ SCHAPOCHNIK, 1998, p.437.

${ }^{173}$ Idem, p.437-8.

${ }^{174}$ Ibid., p.438.
} 
e pretensão fosse evidente, revelavam a intenção de criar uma aproximação com o outro. Ao carregarem consigo a mensagem: "passei por esse lindo lugar e lembrei de você", o envio do postal constituía, sobretudo, um ato lisonjeiro de associar também o destinatário à cena exageradamente. Para os instagrammers, entretanto, o principal objetivo da exibição do "estilo de vida" parece ser despertar a inveja dos seguidores, com um nítido traço competitivo por trás da atitude.

O flâneur, diz Benjamin, sentia-se em casa em meio às multidões que percorriam as galerias e as lojas, do mesmo modo que o burguês sentia-se em casa entre quatro paredes ${ }^{175}$. O usuário de rede social, por sua vez, sente-se confortável diante dos, quiçá, milhares de olhos virtuais que o podem ver. Ele percorre os meandros da rede exibindo os objetos de desejo que garantirão a admiração e a inveja. Faz grande esforço para exibir-se da maneira "correta", por meio de símbolos cuidadosamente escolhidos no âmbito do repertório de sucesso e "coolness": o par de sapatos da moda e um objeto de design exclusivo fazem bonito perante os olhos dos observadores. Não por acaso, os significados se entrecruzam na constatação de que "os pertences garantem o pertencimento" 176 .

Como afirma Ehrenberg, "ser bem-sucedido hoje é poder inventar seu próprio modelo, desenhar sua unicidade, ainda que idêntica a de todos os outros"177. Desse modo, qual é o sentido de "ser si mesmo" senão estar conforme às expectativas normativas em ação, as quais irão definir de antemão

\footnotetext{
175 1989, p.35.

${ }^{176}$ Prickett, 2013.

${ }^{177} 2010$, p.50
} 
a moldura valorativa em que a "autenticidade" se deve encaixar? Não basta, portanto, ser único, ou diferente. Se o "ser diferente" for considerado algo negativo com base em tais critérios, a melhora de si deve ser empreendida para que a unicidade aflore de maneira "positiva" e possa ser convertida em desempenho. O indivíduo que deve agir e decidir por si mesmo (ser autônomo) também deve desenvolver e mostrar suas qualidades únicas (ser autêntico) e extrair o melhor de si ao longo da trilha (performance). Logo, ele é um indivíduo que está sempre em competição para mostrar que é diferente, isto é, que tem algo que o torna especial, e nunca está seguro de seu lugar, pois sempre pode haver alguém melhor do que ele. Por essa razão, esse é um self cronicamente inseguro, que precisa constantemente da confirmação dos outros sobre suas qualidades positivas. E a esse desejo as redes sociais parecem se encaixar perfeitamente, sendo movimentadas pela lisonjaria fácil e imediata das "curtidas" e dos novos pedidos de amizade.

Portanto, é preciso ser si mesmo e ser alguém, e assim, identidade pessoal e ascensão pública caminham no mesmo trilho. Para Ehrenberg, tratase de fazer entrar na intimidade psíquica o modelo da performance: a identidade depende da conquista de um recorde (no caso dos esportes) e da aprovação dos outros obtida por meio da visibilidade, podemos acrescentar. Como disse o empregado da Aérospatiale, na chegada da primeira grande 
corrida das empresas em 1987 178: "Correr de maneira anônima não é realmente algo motivador"179.

Aqueles que conseguirem se destacar no universo do "mostre-se quem puder" serão alçados à condição de modelos de ação, como as moças "saradas" que exibem sua rotina de exercícios físicos, roupas de ginástica e alimentação nas redes sociais para milhares de seguidores ávidos em copiar seu life style ${ }^{180}$. Conquistar esse lugar rende, além da notoriedade, gordos dividendos em troca de uma simples menção a um produto. Como modelos de performance e superação dos limites físicos do corpo humano, elas não apenas seguem a dieta dos vencedores, mas a exibem corretamente ${ }^{181}$. Isto garante seu lugar no laço social, como merecedoras dos aplausos e da admiração dos outros. A rapidez com que esse reconhecimento é convertido em forma monetária é apenas um desdobramento lógico nesse sistema.

\footnotetext{
${ }^{178}$ As competições interempresas, como a grande corrida de empresas organizada pelo jornal francês Le Figaro em 1987, constituem, segundo Ehrenberg, uma "primeira modalidade de relação entre o esporte aventura e a empresa". Nessas competições, "o objetivo é fazer um paralelo entre as qualidades dos campeões e as dos profissionais que se consideram como os campeões de suas empresas" (2010, p.100). Assim, uma boa performance evidencia não apenas o caráter empreendedor dos funcionários, mas cria laços entre eles e com a empresa, constituindo uma estratégia de mudança do indivíduo (idem, p.97).

${ }^{179}$ Idem, p.97

${ }^{180}$ Nesse sentido, não apenas as mercadorias adquirem uma "aura", mas a própria vida se torna uma mercadoria. Como diz Zizeck, "eu compro minha boa forma pagando a academia, compro minha iluminação espiritual num curso de meditação e compro minha imagem indo a restaurantes frequentados por pessoas com as quais quero me sentir associada" (What is a brand? Marketing redefines our lives in strange new ways. Playboy Magazine, 30/12/2013).

181 "Celebridades registram a malhação em sites e redes sociais e engordam o cofrinho". Folha de SP. 01/12/2013.
} 


\subsubsection{Autenticidade e autenticação}

A exibição da autenticidade nas redes sociais é empreendida, via de regra, por meio da exibição de um conjunto de elementos da vida pessoal que compõem, do ponto de vista de quem as exibe, um determinado estilo de vida ou uma imagem ideal. Nesse conjunto, tem lugar de destaque as mercadorias consumidas, bem como outros elementos que deixam entrever que lugar 0 indivíduo deseja ocupar e quem ele pretende ser. Entretanto, as informações oferecidas podem adquirir um sentido completamente diferente para determinados observadores. A menina que gosta de moda, escreve um blog sobre o assunto e cria para si o perfil de "fashionista", desejando assim ser reconhecida, terá o perfil identificado e utilizado por anunciantes que, conhecendo bem suas particularidades por meio do uso de tecnologias avançadas, poderão direcionar as mercadorias adquadas ao seu gosto e estilo de vida. Esse é um exemplo de como a autenticidade torna-se autenticação.

As chamadas "tecnologias de controle da identidade" (identity management), compostas por uma série de mecanismos que pretendem autenticar os indivíduos em vários contextos, tais como reconhecimento facial, scanner corporal, marcas digitais, etc, tornaram-se operação corriqueira dos modos de governança e de práticas comerciais. Serviços online tentam, a todo momento, capturar a autenticidade dos indivíduos: o Google, exigindo informações reais, seja para assegurar a veracidade da identidade dos usuários, seja para determinar com mais precisão o seu perfil, e o mesmo acontece com outras empresas que oferecem esse tipo de serviço. O problema que a autenticação traz para a vida social fica mais claro quando o perfil criado 
pelas empresas ou governos é não apenas distinto do que gostaríamos de revelar, mas serve como forma de controle e segregação social. As tecnologias de autenticação e coleta de dados, seja por operações de segurança ou por meio da CRM - “customer relationship management” (gestão da relação com o cliente) criam cadastros sobre as pessoas e as posicionam em determinadas categorias sociais. Isso aparece, no mercado de consumo, por meio de "promoções exclusivas", descontos especiais, etc. Nas empresas de aviação, por exemplo, o preço de uma mesma categoria de vôo pode variar muito de comprador para comprador, não sendo surpreendente que aqueles que podem viajar na primeira classe encontrem preços melhores do que os que viajam esporadicamente na classe econômica.

Quando essas mesmas tecnologias são utilizadas pela gestão pública, as distorções são ainda maiores. Ao posicionar as pessoas em categorias sociais, tais como a classificação de determinados homens jovens como prováveis infratores, ou a coleta de dados de saúde para determinar o acesso aos serviços, essas tecnologias claramente aprofundam desigualdades sociais existentes. Como observa Virginia Eubanks ${ }^{182}$, as ações de vigilância que hoje surpreendem as classes médias já vinham ocorrendo há muito tempo com populações desfavorecidas: estereótipos de mulheres pobres, especialmente negras, são inerentemente suspeitos e promovem suporte ideológico para programas sociais invasivos que buscam controlar seu comportamento financeiro e social. Do mesmo modo, comunidades de imigrantes são mais suscetíveis à coleta de dados biológicos por terem menor poder político de

\footnotetext{
${ }^{182}$ Want to predict the future of surveillance? Ask Poor Communities. The American Prospect. $15 / 01 / 2014$.
} 
resistência. O que se percebe, portanto, é que além do aprofundamento de desigualdades, essas tecnologias de autenticação e de identificação constituem séria ameaça a direitos civis fundamentais, que ultrapassam o da privacidade.

Portanto, as mesmas tecnologias que permitem que as classes médias realizem seu desejo de parecerem especiais e únicas são aquelas que, ao serem aplicadas às classes pobres, deixam claro o tipo de ameaça que constituem. Se antes seus alvos eram pontuais, hoje, elas incidem sobre todos e a própria classe média sente os efeitos colaterais de seus anseios. Haverá saída para a contradição - que parece nos acompanhar desde o primeiro capítulo da tese - entre o desejo de ceder/tornar pública a informação pessoal e as consequências sofridas a partir desse ato?

\subsubsection{A busca por autenticidade e o narcisismo}

A descrição do indivíduo em busca de autenticidade, o qual se revela inseguro e ávido pela aprovação dos outros é muito semelhante à descrição do indivíduo narcísico feita por Christopher Lasch no livro " $A$ Cultura do Narcisismo" (1983 [1979]). A busca por autenticidade, nesse panorama, nada mais seria do que o invólucro por trás do qual apareceria a decadência da política e o repúdio ao passado. Marca do momento posterior à ebulição política dos anos 1960, ela sinalizaria o recuo dos americanos para as preocupações puramente pessoais: o desenvolvimento psíquico, entrar em contato com os próprios sentimentos, praticar uma alimentação saudável, aprender a relacionar-se, etc. Em outras palavras, o voltar-se para si mesmo mediante o cultivo de tais preocupações egoístas e, por que não, banais, seria 
o triunfo de um modo de vida narcísico, para o qual "soluções políticas não funcionam"183. O argumento de Lasch é bastante forte para ecoar até os dias de hoje e, sem dúvida, não pode deixar de ser lembrado quando se trata de temas como exposição individual, busca de autenticidade, popularidade e afins. Sobretudo em passagens como esta:

"Não obstante suas ocasionais ilusões de onipotência, o narcisista depende de outros para validar sua auto-estima. Ele não consegue viver sem uma audiência que o admire. Sua aparente liberdade de laços familiares e dos constrangimentos institucionais não o impede de ficar só consigo mesmo, ou de se exaltar em sua individualidade. Pelo contrário, ela contribui para sua insegurança, a qual ele somente pode superar quande vê seu "eu grandioso" refletido nas atenções das outras pessoas, ou ao ligar-se àqueles que irradiam celebridade, poder e carisma. Para o narcisista, o mundo é um espelho, ao passo que o individualista áspero o via como um deserto vazio, a ser modelado segundo seus próprios desígnios ${ }^{184}$.

Seguindo essa argumentação, o indivíduo narcísico, distante do próprio desejo, "vazio por dentro e perseguido pelo seu superego sádico", busca desesperadamente a paz de espírito e o preenchimento do buraco interno, seja por meio da terapia, do consumo ou, poderíamos acrescentar, da Internet. Esta, ao oferecer gratificação imediata a uma busca sem objeto definido, seduz o sujeito ao oferecer-Ihe a aprovação intermitente dos outros: ser "curtido" seria o alívio momentâneo à angústia criada pela infindável insegurança do narcisista. A partir dessa perspectiva, cada postagem nas redes sociais seria um pedido de atenção, uma tentativa desesperada de seduzir os outros para escorar o senso titubeante do eu.

\footnotetext{
183 Lasch, 1983, p.25.

${ }^{184}$ Idem, p.30-1.
} 
Argumentação no mesmo sentido, que procura nos mecanismos psíquicos dos indivíduos elementos que ajudem a pensar determinadas questões sociais, propõe entender a exposição de si na Internet como promotora de uma forma de gozo, nos mesmos moldes daquele incitado pela sociedade de consumo. Segundo essa linha $\operatorname{argumentativa}^{185}$, o recuo das formas sociais disciplinares, pautadas no controle externo (presente nas formas de autoridade e hierárquicas) e no adiamento da gratificação (manifesto nas formas de poupança, de acumulação e controle dos gastos) teria dado lugar a um novo modo de vida, mais pautado pelo autocontrole, pelas formas horizontais de organização do poder e pela gratificação imediata. No plano da instância psíquica dos sujeitos, o antigo superego paterno, identificado por Freud no surgimento da psicanálise, repressor do desejo e autoritário, teria sido substituído pelo chamado "superego materno", que em vez de reprimir, instigaria o gozo ${ }^{186}$.

Tal instância revelaria afinidades fundamentais com a chamada sociedade de consumo, na qual o chamado a consumir, instigado pelas formas publicitárias, seria o grande capturador do desejo, mediante a disponibilização de formas vazias que podem ser constantemente reconfiguradas. Com efeito, o

\footnotetext{
${ }^{185}$ Essa argumentação foi melhor desenvolvida em THIBES, M. e MANCINI, P. “A apresentação do eu na sociabilidade virtual: a economia libidinal da amizade" (2013).

${ }^{186}$ Como explica Safatle (2008) sobre o gozo, "a psicanálise trouxe uma noção absolutamente particular de cálculo de interesse, uma noção profundamente não- utilitarista. É tendo isto em vista que psicanalistas como Jacques Lacan insistiram que a inteligibilidade da dinâmica pulsional dos sujeitos não está vinculada à lógica polar do prazer/desprazer. Tal inteligibilidade exige a introdução de um outro campo conceitual com sua lógica própria, um campo que desarticula as distinções estritas entre prazer e desprazer. Este campo organiza-se através de uma noção bastante peculiar de "gozo". Neste contexto, "gozo" não significa o usufruto dos bens dos quais sou proprietário, mas algo totalmente contrário, uma perspectiva de satisfação que não leva mais em conta os sistemas de defesa e controle do Eu, perspectiva que flerta continuamente com experiências disruptivas, ou ao menos com a "retórica" da transgressão (...). Como veremos, isto talvez nos explique uma certa tendência contemporânea em utilizar o gozo como conceito chave para compreender a economia libidinal própria à sociedade de consumo" (p.2-3).
} 
esforço de constituição de uma imagem ideal nas redes sociais teria por base o mesmo mecanismo de renovação de desejos inerente à lógica da sociedade de consumo e necessária para sua reprodução. A apresentação do eu nesses ambientes seria pautada pelo gerenciamento cuidadoso dos símbolos que conferem status, respondendo à demanda de adaptação dos selves ao universo simbólico do capitalismo conexionista. A capacidade de ser bemsucedido nesse universo e obter a gratificação imediata representada principalmente pelas "curtidas", dependeria da exibição correta dos símbolos de sucesso e seria o caminho para aumentar a rede de amigos, um dos maiores sinais de aprovação que o indivíduo pode ter. A necessidade de atualizações e ampliação constantes da rede que esse gerenciamento requer estaria relacionada ao mesmo mecanismo vislumbrado na engrenagem da sociedade de consumo: o imperativo do gozo.

Seria lógico pensar que se as pessoas gastam grande parte de seu dia dedicadas a essas atividades ${ }^{187}$, é porque dela extraem algum tipo de satisfação. No entanto, segundo essa perspectiva, o que motivaria a atividade frenética nas redes sociais seria justamente a impossibilidade de satisfação e a ilusão do desejo realizado, bem como sua constante substituição por outros desejos. Os amigos adquiridos nas redes sociais e toda a aprovação que se parece obter desse universo simbólico não poderiam gerar satisfação, pois seriam apenas modos de administrar o gozo. A aparente liberdade que esses veículos oferecem, conduzindo à ideia de que finalmente é possível "ser o que

\footnotetext{
${ }^{187}$ Pesquisa realizada em março de 2011 pela agência Experian Hitwise mostrou que, no Reino Unido, o acesso a redes sociais superou pela primeira vez os sites de entretenimento, como os que possuem conteúdo pornográfico, por exemplo. No Brasil, pesquisa feita pelo Ibope (2011) mostrou que $72 \%$ dos brasileiros já incorporaram o hábito de acessar redes sociais.
} 
quiser", nada mais seria do que a forma do puro gozo desvinculado dos objetos que, por sua vez, estão condenados à contínua obsolescência, assim como as mercadorias.

A partir dessa análise, a privacidade estaria sendo não só trocada por uma forma de gozo, mas renunciada por adiar a gratificação imediata que a exposição oferece. Assim, se nos expomos para sermos "curtidos", a satisfação obtida desse modo seria algo muito próximo da satisfação pela aquisição de mercadorias, daí a analogia com a lógica do consumo.

Entretanto, a obtenção do gozo apenas explicaria parte da questão da exposição nas redes sociais. Embora acreditemos que ele possa ocorrer como resultado da exposição bem-sucedida de si, o gozo, assim como o narcisismo, diz respeito somente às motivações subjetivas por trás da atitude. É preciso reconhecer que a extrapolação de uma patologia ou estrutura psíquica para caracterizar determinada sociedade possui, inevitavelmente, certos limites, ao remeter a modos de funcionamento individuais. Resta explicar sob quais condições o gozo ocorre e quais são os mecanismos sociais que o viabilizam. Se as "curtidas", mecanismo de aprovação das redes sociais, dependem da exibição "correta" de determinados símbolos presentes no imaginário de sucesso e da felicidade contemporâneos, é preciso entender o que significa estar conforme a esse imaginário para apreender de que modo o gozo pode ocorrer. 


\subsection{Em busca de reconhecimento}

"If you're truly into the moment, you don't interrupt it for a pic. You interrupt it for a pic when you want to appear to be into the moment" ${ }^{\text {"188 }}$.

Uma das teses a que mais se recorre hoje para explicar o ato de exibir a vida privada em meios públicos é a de que os indivíduos que se expõem estão em busca de reconhecimento. Essa tese, baseada na dialética do reconhecimento de Hegel e apropriada por vários autores, com diferentes propósitos, também foi mobilizada para entender a "sociedade de desinibição". O termo, cunhado por Alain Ehrenberg no livro L'Individu Incertain (1995), refere-se às transformações ocorridas ao longo dos anos 1980, cujo pilar central seria o recuo das formas hierárquicas, principalmente no âmbito da família, e que teria resultado na ascensão da TV como veículo para expressão do eu e canal de discussão e resolução de questões privadas.

No lugar da hierarquia, surge como valor a ideia de que devemos nos ajustar ao outro a partir da mobilização das competências pessoais. Desse modo, uma tarefa essencial da vida cotidiana passa a ser dispor dos próprios recursos interpretativos para aceder simultaneamente à compreensão do eu e obter o reconhecimento dos outros ${ }^{189}$. O reality-show, principal exemplo dessa forma televisiva, seria a expressão da busca do laço social: um canal para as demandas de representação e de sentido dispersas pela sociedade e um meio

\footnotetext{
188 "Se você realmente estiver presente no momento, você não o interrompe para tirar uma foto. Você interrompe o momento para uma foto quando você quer parecer estar presente no momento". Comentário feito por um leitor do NYTimes ao artigo de Sherry Turkle: "The Documented Life", publicado em 15/12/2013.

${ }^{189}$ Ehrenberg, 1995, p.169-170.
} 
de buscar a relação consigo e com o outro. Por meio da TV, até o mais humilde dos homens teria direito à visibilidade ${ }^{190}$. Ehrenberg compara o "strip-tease da alma" feito nesses programas com o uso de heroína: o primeiro visaria a procura do outro e a interpretação do eu; a segunda, a blindagem do foro interno e a busca da sensação do eu. Em outros termos, a droga e os realities seriam duas facetas da "responsabilidade do eu" e do governo de si: uma como técnica de ação sobre o eu e a outra de interpretação do eu. Ambas teriam a mesma causa: o indivíduo vítima da incerteza precisa de assistência para compreender seu lugar e para se confortar diante de tal situação angustiante.

A exibição privada na televisão seria, portanto, um meio de ascender à dignidade humana por meio do reconhecimento do outro obtido pela imagem. O que o autor chama de "dialética do reconhecimento de uso popular", fazendo referência a Hegel, seria a exigência de ter uma imagem positiva do eu para ter o sentimento de existir e "estar no laço", uma "autenticação do eu" por meio da imagem ${ }^{191}$.

A tese do reconhecimento também foi utilizada por autores que procuravam explicar o fenômeno da exposição da vida privada na Internet. Harry Blatterer (2010), por exemplo, sugere que a exposição de informações privadas não está apenas relacionada a uma cultura que incita à busca de atenção ou à necessidade insaciável de referências para o eu, mas que a visibilidade é uma motivação a priori cuja expressão é possibilitada, antes de ser causada, pelas tecnologias disponíveis. Essa motivação estaria calcada na busca de reconhecimento, no sentido proposto por Axel Honneth, que também

\footnotetext{
190 Idem, p.185

191 Ibid. p. 190-1.
} 
parte da dialética do reconhecimento de Hegel. Blatterer parte do princípio de que a visibilidade é um constitutivo antropológico e fundamento da necessidade humana de ser reconhecido (ontológico), bem como condição para participação politica; por isso, a tecnologia apenas agiria como facilitador dessa demanda “antropológica e ontológica” dos seres.

Hegel foi o primeiro a perceber que o desejo de reconhecimento é uma dimensão constitutiva do desejo humano. Como explicou Alexandre Kojève ${ }^{192}$,

"(...) o desejo humano deve buscar um outro desejo". (...) "Se a realidade humana é uma realidade social, a sociedade só é humana como conjunto de desejos desejando-se mutuamente como desejos. (...) Assim, na relação entre homem e mulher, por exemplo, o desejo só é humano se um deles não deseja o corpo mas sim o desejo do outro, se quer possuir ou assimilar o desejo considerado como desejo, isto é, se quer ser desejado ou amado ou, mais ainda, reconhecido (grifo meu) em seu valor humano, em sua realidade de indivíduo humano" (...) "todo desejo humano, antropogênico, gerador da consciência-de-si, da realidade humana, é, afinal função do desejo de reconhecimento. Sem essa luta por puro prestígio nunca teria havido seres humanos na Terra"

Depois de Hegel, Jacques Lacan e Axel Honneth também se basearam no modelo do esforço de reconhecimento de Hegel desenvolvido em seus anos em Jena. Como explica Joel Anderson no prefácio ao livro de Honneth (1995), este toma de Hegel a ideia de que o desenvolvimento integral do ser humano depende de relações éticas bem estabelecidas, o que somente pode se dar a partir de um processo de desenvolvimento conflituoso, guiado pelo esforço de reconhecimento (p.xi). A abordagem de Honneth poderia ser sintetizada da seguinte forma:

192 [1947 (2012)], p.13-4. 
A possibilidade de perceber e interpretar as necessidades e desejos dos outros como indivíduos autônomos - em suma, a própria possibilidade de formação da identidade - depende fundamentalmente do desenvolvimento de autoconfiança, respeito próprio e auto-estima. Essas três formas de relação consigo próprio só podem ser adquiridas e mantidas intersubjetivamente, por meio da obtenção de reconhecimento pelos outros que ele próprio reconhece. Como resultado, as condições para a auto-realização tornam-se dependentes de relações de reconhecimento mútuo ${ }^{193}$.

Portanto, se o reconhecimento está presente como dimensão básica do desejo humano, é natural que ele esteja também manifesto nas motivações que levam as pessoas a se exporem. Nesse sentido, a conclusão lógica seria a de Blatterer, isto é, de que apenas os veículos utilizados para buscar o reconhecimento é que mudaram. Mas, creio que chegando até aqui, pouco se explica. Não se responde, sobretudo, à intensidade que a demanda de exposição adquire no capitalismo contemporâneo. Se a tese do reconhecimento puder ser mantida, então, talvez seja mais profícuo perguntar, como já notara Ehrenberg no começo dos anos 90, por que os indivíduos estariam tão ávidos de reconhecimento a ponto de trocarem a própria privacidade por ele ou qualquer outro bem social.

O ponto é que, se a construção de si se tornou um sonho igualitário, os poucos que conseguirem destacar-se no universo do "mostre-se quem puder" serão alçados à condição de modelos de ação, como os instagrammers que exibem detalhes de sua vida pessoal para milhares de seguidores ávidos em copiar seu estilo de vida. A conquista desse lugar é convertida não apenas em notoriedade, mas em retorno monetário. Os indivíduos que se exibem hoje não estão apenas à procura de auxílio na difícil tarefa de se compreenderem, como

\footnotetext{
${ }^{193}$ Honneth, 1995, p.xi.
} 
propôs Ehrenberg. Eles perceberam que podem obter, a partir de sua exibição bem-sucedida, muitos retornos além do conforto existencial. Resta compreender de que modo essa exibição deve ser realizada, isto é, quais são os critérios que ela deve atender para que os frutos almejados sejam conseguidos, tarefa que será realizada no próximo ítem desse capítulo. Suspeitamos que ela passa por um minucioso e atento gerenciamento de si e da imagem online que procura atender aos critérios de sucesso presentes no universo simbólico do capitalismo conexionista.

Para encerrar, resta um adendo. Embora exibir-se pareça estar ao alcance de todos, como uma benesse democrática, e apareça como um imperativo da ordem do sucesso, o reconhecimento virtual nem sempre compensa a sua falta no mundo real. Recentemente apropriados pela "nova classe média" no Brasil, o Facebook e o Instagram parecem ter feito com que a exibição de si online e a busca de reconhecimento por meio dela fossem democratizadas. A ideia de que qualquer um pode tornar-se uma celebridade e lucrar com seus talentos, que antes ficariam invisíveis, fez com que muitos exaltassem o potencial democrático da Internet. Entretanto, nem tudo o que reluz no mundo virtual se transforma em ouro no mundo real. Os garotos pobres que ostentam seus pertences nas redes sociais não deixarão de ser barrados no shopping center porque foram "curtidos" no Facebook. Os limites de ascensão de uma classe não podem ser corrigidos por meio da Internet, assim como ela também não pode suprir a ausência de respostas políticas a problemas sociais. 
Até o momento, expusemos algumas das principais teorias que procuram explicar a exposição de si online. Todas elas têm em comum o fato de partirem das motivações individuais por trás dessa prática: a primeira defende que os indivíduos estão em busca de autenticidade; a segunda, que a origem desse comportamento está relacionada à generalização do narcisismo; a terceira, que os indivíduos obtêm o gozo, por meio da exposição; e a última acredita que o desejo a mover essa prática seria o de reconhecimento. Porém, se nelas o indivíduo desempenha grande papel, não é possível dizer o mesmo a respeito da formação sócio-histórica na qual a prática está enraizada. Em outras palavras, a relação entre as atitudes individuais e as transformações sociais é desequilibrada pelo excesso de peso dado às motivações subjetivas para o fenômeno em questão. No próximo item, portanto, tentaremos realizar o trajeto oposto ao dessas interpretações, isto é, buscar em quais processos sociais - que apesar de autônomos em relação aos processos psíquicos individuais, não deixam de estabelecer com eles uma sinergia, a exposição de si online está ancorada.

\subsection{A exposição online de si online como adaptação aos valores do "capitalismo "conexionista}

No começo do capítulo aventamos a hipótese de que motivações poderosas estariam em jogo para que as pessoas abrissem mão da privacidade de suas informações pessoais ao se exporem na Internet. Como mostrou a fala da moça entrevistada por Gershon ${ }^{194}$, a competição por bens

${ }^{194}$ Ver p. 119. 
sociais de importância fundamental entra em ação na hora de criar e gerenciar o eu virtual, desde os simbólicos - como a reputação (ou a preservação da face/ fachada, se quisermos usar o termo de Goffman), o reconhecimento dos pares, o capital social e o status -, aos bens concretos - como parceiros amorosos, empregos e amigos. No caso da moça, havia a competição pelo amor do namorado. Por meio do que ela chamou de sua "popularidade", ou de sua correta apresentação na rede social, ela sentia que ganhava a competição com a outra garota, ao ostentar uma imagem ideal, pouco importando se, na verdade, não conseguisse corresponder a ela, e as relações exibidas no perfil fossem apenas de fachada. Resta entender quais são os critérios que informam essa competição e embasam a construção dessa imagem ideal.

A minha proposição é a de que a constelação valorativa própria ao "capitalismo conexionista" cria um cenário no qual se expor, publicizar os feitos, as realizações e as qualidades do eu, nas redes sociais e na Internet em geral, se torna extremamente importante para obter acesso a bens sociais fundamentais: um trabalho, um par amoroso, amigos, conexões e reconhecimento. Fato importante e ubíquo: desde os bandidos do Guarujá até o presidente Obama aderem ao modo de exibição, ostentando a própria imagem nos domínios virtuais, independente das consequências que o ato possa ter.

Já sabemos que na etapa histórica denominada por Boltanski e Chiapello (2009) como "terceiro espírito do capitalismo", ou "capitalismo conexionista", a vida pessoal, tendo estado distante do mundo do trabalho no começo do século $\mathrm{XX}$, é novamente trazida à baila e incorporada ao sistema produtivo, adquirindo papel central na constelação valorativa do capitalismo 
avançado. Neste período, no âmbito do trabalho, os modos de controle típicos da sociedade disciplinar - controle externo, hieraquia e adiamento da gratificação - foram substituídos pelo autocontrole e por mudanças condensadas no eixo da flexibilidade. A interpretação da crise do capitalismo como crise do taylorismo provocou, no início dos anos 1970, certo número de iniciativas patronais de mudanças na organização do trabalho. Os critérios de seleção passaram a privilegiar os mais adaptados às novas exigências do mercado de trabalho. Além dos tradicionais critérios de idade, sexo e nacionalidade, as provas que a sociedade contemporânea passou a exigir, por meio das quais se efetua a seleção social das pessoas e é decidido quais serão bem-sucedidas e quais não o serão, passaram a ser relacionadas às características de autonomia, empreendedorismo, iniciativa, flexibilidade (para trabalhar em múltiplos projetos), comunicabilidade, equilíbrio psicólogico (capacidade de suportar pressão), sociabilidade (para fazer contatos), entre tantas outras características pessoais, individuais, que devem ser cultivadas e reveladas.

Diferente do segundo espírito do capitalismo, em que vigorava a nítida separação das aptidões profissionais e pessoais dos trabalhadores, no terceiro, essas duas dimensões da vida foram fundidas. As qualidades mais "pessoais" dos indivíduos, isto é, aquelas relacionadas ao seu "caráter", passaram a ser vigorosamente valorizadas. Mediante técnicas da psicologia do trabalho, é feita a seleção de candidatos que possuam essas características e que são, presumidamente, mais adaptados (ou adaptáveis) às novas exigências do mundo empresarial. 
No entanto, a posse dessas características não é apenas um dado genético; é preciso cultivá-las para desenvolver os recursos internos individuais. Num mundo cheio de riscos, o investimento no eu pode ser considerado certeiro, por transmitir a ideia de que se depende apenas de si mesmo para realizá-lo. O empresário de si mesmo é aquele que cultiva as qualidades individuais e garante uma boa imagem de si. Esta, por sua vez, resulta em boas redes, boas conexões e amplo reconhecimento. Desse modo, o cultivo do "cartão de visitas do eu", longe de ser apenas um exercício frívolo de alimento das vaidades, está em harmonia com os valores próprios do mundo conexionista.

Entretanto, o cultivo das qualidades individuais não é suficiente nesse capitalismo. Como disse Boltanski e Chiapello sobre o networker (ou redeiro), é preciso que, "no fim de um projeto, algo the seja atribuído e publicamente associado a seu nome"195. Sem esse último passo, isto é, sem a publicização dos feitos, das realizações e dos atributos que constituem as provas, 0 exercício não está completo. E, sem dúvida, as redes sociais têm grande papel como vitrine para a apresentação do eu e para exibição das características "certas", dos sinais de sucesso, que garantirão a ampliação das conexões e o reconhecimento dos pares.

Em tempos de Internet, não basta ter um bom currículo e obter bom desempenho durante a entrevista; a imagem online necessita ser correspondentemente atrativa. Tornou-se frequente os empregadores checarem as informações disponíveis na Internet em busca de dados reveladores sobre os candidatos ou mesmo para entrar em universidades. É ${ }^{195} 2009$, p.368 
suposto que as informações encontradas online revelem tanto ou mais do que se apreende na entrevista tradicional.

A quantidade de amigos no Facebook, por exemplo, pode ser quesito a ser julgado numa seleção profissional. Na pesquisa de Gershon ${ }^{196}$, alguns estudantes relataram que potenciais empregadores checaram seus perfis no Facebook para saber quantos amigos tinham, como medida de seu potencial para constituir redes de contatos. Nos Estados Unidos, houve o exemplo de uma jovem que, durante sessão de apresentação da universidade para estudantes em fase de ingresso, postou, em seu perfil do Twitter, comentários desrespeitosos sobre os colegas presentes no mesmo evento ${ }^{197}$. Talvez ela não soubesse que as faculdades monitoram as ações de candidatos nas mídias sociais, mas essa postagem custou-lhe a admissão na universidade, que Ihe foi negada.

A razão para esse tipo de monitoramento, segundo as universidades, é que a maior parte delas não possui políticas formais de admissão, recorrendo à pesquisa online para suplementar o registro dos estudantes. Embora com frequência possam basear-se em registros falsos e não confiáveis, acreditam que essa seja a melhor maneira de realizar uma boa seleção. Em 2012, um estudante de graduação do Pitzer College, na Califórnia, denunciou um amigo do Facebook que estava concorrendo a uma vaga na universidade porque notou que o candidato havia postado comentários ofensivos sobre um de seus antigos professores. "Pensamos que esse não é o tipo de pessoa que gostaríamos de ter em nossa comunidade", disse o diretor de admissões e

\footnotetext{
196 2011, p.876.

${ }^{197}$ Singer, Natasha. They Loved Your G.P.A. Then They Saw Your Tweets. NYTimes. November 9, 2013
} 
auxílios financeiros da faculdade. "Com mais de 4.200 candidaturas anuais para uma classe de 250 alunos, a faculdade pode dar-se ao luxo de ser seletiva"198.

$\mathrm{Na}$ tentativa de ajudar os estudantes de high school a evitarem o comprometimento de sua imagem online, consultores especializados os ajudam a gerenciar sua identidade digital para apagar rastros comprometedores. Na Brookline High School, em Massachussets, por exemplo, os alunos são ensinados a apagar posts ou fotografias que façam alusão ao uso de álcool e a criarem endereços de email com nomes aceitáveis.

O mesmo ocorre no mundo do trabalho. Além da quantidade de amigos e o número de comentários recebidos em cada postagem, as informações divulgadas nas mídias sociais podem ser decisivas para uma contratação. Uma pesquisa realizada pela empresa CareerBuilder descobriu que pelo menos 37\% dos 2.303 gerentes e profissionais de $\mathrm{RH}$ pesquisados utiliza(va)m redes sociais para verificar potenciais candidatos. Isso significa que 2 em cada 5 companhias procuram informações online sobre seus candidatos, a fim de avaliar seu "caráter e personalidade". Acerca das razões para o uso das redes sociais com esse propósito, $65 \%$ afirmaram que o fazem para verificar se 0 candidato se apresenta "profissionalmente" online, $50 \%$ queriam saber se 0 perfil do candidato se encaixava na cultura da empresa e outros $45 \%$ queriam conhecer melhor suas qualificações. ${ }^{199}$

\footnotetext{
198 Idem.

199 Jacquelyn Smith. "How Social Media Can Help (Or Hurt) You In Your Job Search”. Revista Forbes. 16 de abril de 2013.
} 
A mesma pesquisa mostrou que um terço dos empregadores disse que encontrou em sua busca algo que os fez não contratar algum candidato, como fotos provocativas, informações inapropriadas ou evidência de uso de álcool e outras drogas. Outras razões para a desistência da contratação seriam a demonstração de poucas habilidades comunicativas no perfil, a difamação de antigos empregadores, ou comentários ofensivos relacionados a gênero, etnia ou religião.

Contudo, os empregadores também disseram encontrar informações que incentivaram a contratação, tais como a demonstração de uma personalidade interessante no perfil da rede social. Em outros casos, o candidato criou uma boa imagem profissional ou apresentou evidências de que as informações de seu currículo eram verdadeiras. Houve ainda casos de postagens de boas referências sobre os candidatos feitas por colegas ou a demonstração de qualidades, tais como criatividade, boas conexões e habilidades comunicacionais.

A orientação da empresa que realizou a pesquisa e dos redatores da revista Forbes é de que os candidatos não deixem de postar informações nas redes sociais por medo da rejeição de potenciais empregadores, mas sim que "trabalhem para criar boas redes e perfis online que representem positivamente suas habilidades e suas experiências profissionais". E acrescentam: "Canditatos silenciosos ou invisíveis online estão em desvantagem. Eles precisam engajar-se nas redes sociais para aumentarem sua visibilidade e sua procura para eventuais empregadores".

Helene Cavalli, vice presidente de marketing na Lee Hecht Harrison, concorda: "Não é suficiente apenas manter um perfil e checar as atualizações. 
É preciso ser ativo, produzir conteúdo, participar em discussões de grupo, compartilhar expertise, indicar um artigo para alguém. Você tem de trabalhar em cima de seu perfil. Ainda que se sinta desconfortável fazendo isso, se está à procura de emprego, ser tímido só irá prejudicá-lo".

A coleta de informações pessoais, entretanto, não se limita ao processo seletivo. Muitas empresas têm utilizado tecnologias de medição digital e monitoramento de atividades para descobrir quais características e comportamentos estão envolvidos no desempenho bem-sucedido de tarefas, para identificar com precisão não somente os melhores desempenhos, mas quais características pessoais apresentam. Cada email, mensagem, ligação telefônica e página navegada deixa rastros que podem ser seguidos pelos gestores. O time de cientistas especialistas em comportamento em Knack, uma firma do tipo start-up do Vale do Silício, por exemplo, utiliza jogos de computadores e medições constantes, para testar a inteligência emocional, as habilidades cognitivas, a memória de trabalho e a propensão a assumir riscos de seus empregados.

Essas informações, obtidas sem nenhum esforço ou gasto, com a ajuda da tecnologia, fornecem insights sobre como as pessoas trabalham e se comunicam no ambiente de trabalho, com a justificativa de aumentar a eficiência e a inovação das empresas. Nesse sentido, as chamadas "provas" que a sociedade exige dos indivíduos, também devem ser apresentadas online. Porém, na Internet, há uma tensão inerente à sua própria estrutura de funcionamento, que dificulta atestar a veracidade das provas. Como saber se a imagem transmitida pela tela é real? Por essa razão, as provas dadas e o 
monitoramento devem ser contínuos, para que sejam capturadas eventuais falhas, encobertas durante as primeiras avaliações.

Assim, não resta dúvidas de que a atividade online dos usuários de Internet, mediante a criação de uma imagem atrativa, é decisiva para garantir uma série de benefícios; por isso, essa imagem torna-se objeto de gerenciamento minucioso, pois o investimento pode ter grandes retornos.

A Internet é o espaço ideal para a criação e manipulação dessa imagem, na medida em que ela liberta o indivíduo dos constrangimentos da imagem física e permite selecionar com mais precisão os elementos favoráveis para forjar a apresentação do eu. Se, como afirma Ehrenberg, o indivíduo autônomo deve produzir sua própria saúde, sua aparência física e sua implicação na vida profissional (2010, p.26), do mesmo modo, ele deve ser o empreendedor de sua existência online.

Embora os sinais de sucesso, os códigos das provas, não sejam democraticamente partilhados - ao contrário, são possuídos (e guardados) pelos poucos que tiveram a sorte de não ter limitações (físicas, sociais e psicológicas) que os prejudicassem - eles são compartilhados no nível simbólico e largamente presentes no discurso contemporâneo. Nesse sentido, é facilmente observável a tentativa de exibição desses sinais nas redes sociais; afinal, ninguém deseja aparecer como perdedor e um retrato virtual bem constituído pode agir como uma primeira boa apresentação e oferecer gratificações valiosas, mesmo quando não sustentada no mundo físico, como mostra o exemplo da garota que disputava o namorado, no início do capítulo. 
Embora ela se sentisse de modo totalmente diferente do que aparentava em seu perfil no Facebook, o fato de ostentar critérios de popularidade e sucesso em sua imagem virtual a fazia sentir certo regozijo, que, se não capaz de compensar os fracassos da vida real, ao menos serviria para manter uma imagem de si mais condizente com as expectativas dessa normatividade social para a qual ter poucas conexões é sinal de derrota. 


\section{Capítulo 4: A economia das novas tecnologias da informação: transformações econômicas, técnicas e no mundo do trabalho}

Vimos que a exposição de informações pessoais em ambientes online, principalmente em redes sociais, é um fenômeno ancorado em diversas motivações e que pode ser explicado de diversas maneiras. Entretanto, a explicação que julgamos mais adequada para entendê-lo diz respeito à sua relação com as demandas do capitalismo conexionista. Nesse sentido, exporse não poderia ser considerado um ato fútil, fruto da vaidade e da aspiração à notoriedade, mas sim, um imperativo reconhecido e demandado pela normatividade social atual. Dessa forma, é indispensável que seja realizado um investimento na imagem transmitida virtualmente para que haja 0 reconhecimento dos pares (membros da rede) e de possíveis empregadores. A exposição de si bem-sucedida irá garantir não apenas aprovação virtual, mas benefícios reais: mais amigos, conquista de parceiros amorosos e empregos.

Por trás das motivações e gratificações individuais que movem o ato da exibição online de sionline, procuramos frisar a existência de um condicionante social, que opera no nível simbólico, e informa quais são os valores a serem ostentados nas apresentações. Esses valores já foram desvendados por autores tais como Boltanski e Chiapello, e Alain Ehrenberg, sendo que nosso trabalho aqui foi, em suma, mostrar como se dá a relação entre a exposição de si nos espaços virtuais e esses valores. Sobretudo, tratamos de mostrar como a materialização de tais valores adquire uma nova forma: não basta captá-los e incorporá-los, tampouco apenas praticá-los. É preciso exibi-los nos espaços virtuais. Essa atividade, não por acaso, adquire conotação profissional: criar 
uma boa imagem de si é algo que requer perícia e trabalho, que pode não ser remunerado para a maioria das pessoas (embora o seja em alguns casos), mas vem com a promessa de benesses futuras. Desse modo, cria-se a impressão de que a informação pessoal é passível de gerar valor: simbólico e monetário.

Entretanto, voltemos por um instante aos conflitos tratados no início da tese. Apesar de sua natureza aparentemente diversa, todos possuíam em comum o fato de revelarem tensão entre a informação caracterizada como privada e as transformações que a tecnologia engendrou desafiando a privacidade da informação. Retomando a definição de privacidade de Helen Nissembaum, uma informação poderia ser considerada privada apenas em relação ao contexto no qual ela circula. Assim, um indivíduo que escreve mensagem que considera pessoal para um amigo no Facebook espera que este seja o único destinatário do recado, e que o conteúdo da mensagem não seja, portanto, acessado por mais ninguém (nesse caso, apropriado pela rede e vendido a terceiros). Do mesmo modo, um paciente não espera que seu analista revele para outras pessoas as informações ditas no consultório. O que constitui o caráter privado da informação, portanto, não é local em que é dito (público, no caso da rede social, e privado no caso do consultório do analista), mas as circunstâncias e as regras que cada contexto relacional comporta. Essa definição tem como pressuposto, embora não discutido pela autora, o princípio de que somos proprietários da informação que partilhamos a nosso respeito e que, portanto, nos vemos no direito de ter controle sobre ela, manipulando-a a nosso favor e esperando que ela não circule para além dos limites intencionados. 
Porém, esse princípio não só é desafiado a partir da popularização das novas tecnologias da informação, como contém uma contradição em sua própria essência. A informação apresenta todas as características de um bem público. Segundo a teoria econômica neoclássica, os bens podem ser classificados por serem rivais ou não-rivais e como excluíveis ou não excluíveis. Um bem é rival quando seu consumo por uma pessoa reduz a quantidade disponível para os outros. Um bem é excluível se é possível impedir que alguém o consuma, por meio de algum cercamento, por exemplo. Quando os bens são rivais e excluíveis, são privados. Se não forem nem rivais nem excluíveis, tornam-se públicos ${ }^{200}$. A informação, além de não ser um bem rival, pois o seu "consumo" por alguém não reduz sua disponibilidade para os demais, não é excluível, pois qualquer pessoa pode reproduzi-la a custo desprezível, como ocorre com a pirataria de softwares, músicas e filmes. Portanto, a única forma de garantir que a informação gere valor monetário é por meio dos direitos de propriedade sobre ela (idem), ou, como diz Prado (2005), por meio de novos "cercamentos".

Assim, a partir do momento em que compartilho uma informação a meu respeito, em essência, já não posso mais me considerar "dono" dela, pois ela já é imediatamente posse também de um outro, que pode reproduzi-la sem custo algum. No caso da informação pessoal presente na Internet, esse outro não é apenas o destinatário da informação, mas, também, o próprio provedor dos serviços, que se vale da posse de tais informações para movimentar seus negócios. Nesse sentido, assumimos que a intimidade passa a ter valor monetário e a ser comercializada como uma mercadoria qualquer. Desse

${ }^{200}$ Teixeira, 2009, p.443 
modo, a informação privada é "valorizada" em duas dimensões fundamentais: simbólica, na medida em que sua exposição adequada aos valores do capitalismo conexionista garante o acesso a bens sociais, e material, por meio de sua valorização monetária.

No entanto, como é possível que a intimidade possa ter valor como qualquer outra mercadoria? Se aprendemos com Marx que o que confere valor a uma mercadoria é o tempo de trabalho socialmente necessário para reproduzi-la, de que modo a vida privada, apropriada sem que houvesse um trabalhador sendo pago para reproduzi-la, pode gerar valor? Qual é, portanto, a natureza do trabalho do usuário que produz essas informações e os ganhos auferidos a partir de sua exploração? Se é certo que há condicionantes poderosos por trás do ato da exibição da vida privada, resta entender os mecanismos que tornam a intimidade revelada apropriável pelo capital. Acreditamos que, sem esclarecer esse ponto, não é possível entender devidamente a intrincada posição que a vida privada assume no capitalismo contemporâneo.

\subsection{A renda do conhecimento}

Na chamada era da "pós-grande indústria" (Fausto, 1989; Prado, 2005), o conhecimento adquire papel central no processo de valorização do capital a ponto de ser considerado como o carro-chefe da economia global. Nesse tipo de economia, novos bens, da ordem do conhecimento, tornam-se mercadorias aparentemente dotadas de valor como qualquer outra mercadoria comum. Sua natureza, entretanto, e a forma como geram valor, são difíceis de apreender e 
suscitaram diversas interpretações. Aqui propomos que as informações pessoais presente nas redes sociais e outros serviços online são constituídas do mesmo modo que as "mercadorias do conhecimento"201", isto é, compartilham da mesma natureza e do mesmo processo de geração de renda.

Tomemos como exemplo as informações que os usuários do Facebook compartilham com sua rede de contatos. Desde os primórdios da chamada sociedade de consumo, as informaçoes pessoais eram consideradas fundamentais pelos setores de marketing, para orientar suas ações e direcionar negócios. Entretanto, essas informações só poderiam ser custosamente obtidas por meio de estratégias tradicionais de pesquisa, que demandavam muitos recursos financeiros e, sobretudo, careciam de vasta mão-de-obra para serem realizadas. Ainda assim, com frequência, não era simples atingir o alvo: entender os desejos dos consumidores e direcionar as mercadorias para o público certo permanecia uma missão difícil. Com a popularização da Internet e, principalmente, das redes sociais, essas informações adquiriram novo fluxo: passaram a circular abundantemente em ambientes virtuais, além de serem constantemente renovadas, permitindo que desejos e tendências sejam mapeados com rapidez inédita e até mesmo antecipados de modo preciso. Desse modo, não à toa, tornaram-se a "galinha dos ovos de ouro" da

\footnotetext{
${ }^{201}$ Essas seriam "mercadorias sui generis" (Teixeira, 2009, p.422), pois não podem ser vendidas ou compradas, mas apenas "cedidas ou emprestadas". Sua natureza "sui generis" deriva do fato de que, embora tenham alto custo de produção, possuem, ao mesmo tempo, um custo de reprodução muito baixo, quase nulo. Portanto, para que o capital investido possa ser recuperado com juros há que se ter necessariamente uma mudança na forma da comercialização. $O$ capitalista não pode vender 0 conhecimento como mercadoria, mas terá de transferir o direito de usá-lo por meio de um contrato que resguarda o seu próprio direito de propriedade por meio de certas garantias jurídicas (Prado, 2005, p.107). O embate, como veremos, gira em torno da forma como os proprietários dessa mercadorias auferem seus rendimentos a partir delas: enquanto para Prado (2005) e Fausto (1989), esse rendimento assume a mesma natureza do capital financeiro, isto é, dos juros, para Teixeira (2009), a renda do conhecimento é da mesma natureza da renda da terra no sentido proposto por Marx.
} 
publicidade e rapidamente dão ímpeto a um novo de tipo de negócio e, já se tornou comum dizer, a uma nova forma de economia: a digital.

O novo modo de circulação, apreensão e troca de informações fez com que estas, subitamente, adquirissem "valor" para os proprietários das empresas online e passassem a ser, inclusive, comercializadas como qualquer outra mercadoria. Nas pesquisas de mercado tradicionais, supõe-se que toda informação revelada pelo pesquisado é consentida. Os pesquisadores só têm conhecimento daquilo que foi voluntariamente dito pelo pesquisado, com 0 objetivo de colaborar com a pesquisa. Ou, invertendo os termos, o pesquisado sabe exatamente o que foi conhecido a seu respeito pelo pesquisador, pois isso se resume ao que lhe foi dito por ocasião da entrevista. Ou seja, além de ter podido controlar as informações concedidas, estas dizem respeito a um contexto específico, o da entrevista para uma pesquisa, em que a participação foi conhecida e consentida - logo, é uma situação que obedece as regras da privacidade em contexto (Nissembaum, 2009). No caso das informações captadas pelas redes sociais, os usuários "sabem" que suas informações serão utilizadas, mas 1) são informações que pertencem a outros contextos, distintos de uma entrevista de pesquisa de mercado; 2) não sabem quais informações e para que fins elas serão utilizadas; 3) não consentem em participar de nenhum tipo de colaboração específica; apenas, ao aceitar as políticas do site, estão autorizando o uso de todas as informações ali presentes, pela rede social. Subentendido por trás do contrato de uso das redes sociais e outros serviços online oferecidos "gratuitamente", há o princípio de que as informações pessoais são trocadas pelos serviços. Desse modo, na ausência de pagamento 
monetário, a mercadoria é o próprio usuário, isto é, suas informações pessoais, sua vida privada e sua intimidade.

Contudo, para entendermos como as informações pessoais se caracterizam como mercadorias, é preciso rastrear as origens desse processo, partindo do modo como as empresas de tecnologia se constituíram como negócios que desfrutam de posição hegemômica na economia global e geram riqueza, e a forma como essa riqueza se relaciona à apropriação da informação pessoal.

\subsection{0 setor econômico da informação e sua geração de riqueza}

O surgimento da microinformática, nos anos 1970, e sua disseminação para os domicílios, a partir dos anos 1980, fez surgir novas formas de atividades e novos tipos de organização do trabalho e dos recursos humanos, sejam eles financeiros ou da ordem do conhecimento. Como explica Nicholas Carr (2008), durante os anos 1980, as Tls (Tecnologias da Informação) foram rapidamente se tornando mercadorias, passando, de um bem caro e proibitivo para a maioria das empresas, um investimento de alto risco apenas disponível a altos capitais em iniciativas pioneiras, para uma mercadoria cada vez mais padronizada, amplamente disponível, produzida em massa, por um preço rapidamente deflacionado. Dessa forma, as Tls passaram de um ativo particular de uma empresa específica para algo "compartilhado" pelas empresas, largamente disponível a todas elas. Nesse processo, sua posse deixou de representar uma vantagem competitiva. Assim, como mostra 
Lucas $^{202}$, a fórmula do sucesso dessas empresas, que lhes permitiu contornar esse aparente paradoxo, foi a busca de lucro em outras fontes, ou a mudança para outras linhas de produção, como mostram o exemplo das gigantes: o Google, que oferece a maioria de seus softwares de graça, mas extrai lucro a partir do marketing; a Amazon, vendendo livros e outras mercadorias não ligadas à tecnologia, mas investindo na produção de gadgets; e a Apple, cujo lucro possui como fonte significativa a venda de músicas e outros conteúdos por meio do seu programa Itunes.

O Twitter, também um desse exemplos, recentemente foi avaliado em 24 bilhões de dólares. Ele possui mais de trinta milhões de usuários ativos, que não pagam nada para utilizar o serviço. No entanto, os lucros da companhia estão avaliados em 535 milhões. De acordo com James Surowiecki ${ }^{203}$, isso cria, economicamente, uma situação estranha: mercadorias e serviços digitais estão em toda parte, mas seu impacto é difícil de medir nas estatísticas econômicas. Um dos principais índices utilizados para medir a saúde de uma economia é o PIB (produto interno bruto), uma medida criada nos anos 1930 pelo economista Simon Kuznets. Sua premissa é a seguinte: quanto mais se produzir para vender, mais a economia crescerá. $\mathrm{Na}$ era industrial, isso fazia sentido; mas, numa economia digital, torna-se mais difícil medir a extensão real do crescimento, já que grande parte do que se produz é consumido sem pagamento. Dessa forma, empresas como Twitter, Facebook e Google sequer existem do ponto de vista do PIB. Isso cria um retrato distorcido da economia.

\footnotetext{
202 Lucas, R. The Critical Net Critic. New Left Review 77, Setembro/Outubro de 2012.

${ }^{203}$ Surowiecki, J. Gross Domestic Freebie. The Financial Page, The New Yorker. 25/11/2013.
} 
Como observa o economista Erik Brynjolfsson ${ }^{204}$, de acordo com as estatísticas governamentais, o setor econômico da informação - que inclui publicação, software, serviços de dados e telecom - mal cresceu desde o fim dos anos 1980, apesar da explosão na quantidade de informação e dados consumidos. Para o economista, isso "parece muito errado".

Ele conclui que, se tudo na Internet fosse pago, esse problema não existiria, pois se todos resolvessem pagar pelos softwares da Microsoft, por exemplo, o impacto no PIB seria facilmente percebido, já que poderia ser medido como o de uma mercadoria comum. Mas, como não é o que ocorre, conclui-se que a era digital está encolhendo o PIB da economia americana (a maior produtora desse tipo de mercadoria e sede das maiores empresas de tecnologia).

Capturar o valor invisível produzido a partir da Internet tornou-se uma tarefa complexa. De acordo com Surowiecki ${ }^{205}$, uma estratégia seria medir o tempo que as pessoas gastam online (já que ao gastar tempo, também se gasta dinheiro). Ele cita um estudo feito pelos economistas Brynjolfsson and Joo Hee Oh apontando que, em 2011, o valor das mercadorias gratuitas na Internet era de centenas de bilhões de dólares, e que esse valor estaria aumentando anualmente em uma taxa de mais de 40 bilhões de dólares. Como é possível que mercadorias pelas quais não se paga possam gerar tamanha riqueza? Quando se trata de um bem concreto, a tarefa de medir o valor é simples; no entanto, de que modo exatamente o valor da Internet é produzido? - se é que os produtos da Internet contêm, de fato, valor.

\footnotetext{
${ }^{204}$ Citado por Surowiecki (2013).

${ }^{205}$ Idem.
} 
Para Surowiecki, a pista para compreender esse valor viria do trabalho, isto é, de todo trabalho realizado para produzir esse tipo de bem. A Wikipedia, por exemplo, resultado do trabalho gratuito de milhares de pessoas mundo afora, dispostas a gastar seu tempo para criar artigos informativos, é ótima para quem lê, mas péssima para os produtores de enciclopédia tradicional (que seriam capazes de engrossar o PIB).

No campo do trabalho, as mudanças seguiram o mesmo rumo que nos outros âmbitos da economia digital; na medida em que esta não requer a mesma quantidade de força de trabalho que as formas produtivas tradicionais, uma grande quantidade de trabalho torna-se desnecessária. Além disso, a Internet também foi responsável pelo declínio das indústrias tradicionais associadas à informação, como jornais, revistas e radiodifusão. Como observa Lucas (2012), entre 2001 e 2007, o emprego nas editoras americanas e nas indústrias de radiodifusão havia diminuído treze por cento, de acordo com o Departamento do Trabalho dos EUA, sem aumento correspondente nos empregos relacionados à Internet. Segundo os dados mais atualizados do autor, os empregos americanos nas editoras tiveram queda de quase trinta por cento desde 2001. Segundo Hardt e Negri, isto seria resultado da prevalência do modelo das redes, rizomático e descentralizado, sobre o modelo tradicional, centralizado e oligopolista, a partir de um único ponto de emissão das emissoras tradicionais.

De qualquer forma, empresas tradicionais de informação, bem como as formas de trabalho associadas a elas entram em declínio, sem que haja um correspondente aumento de emprego no setor novo da informação. Por outro lado, os dados da OECD mostram que a força de trabalho mundial cresceu 
quase $8 \%$ nos últimos dez anos ${ }^{206}$. Só na China, o total de empregados é estimado em torno de 750 milhões de pessoas, ou uma vez e meia o total de toda OECD e quase dez vezes o total de empregados no Japão e na Coréia ${ }^{207}$.

Parte da explicação é que o setor da nova informação não carece da mesma quantidade de mão-de-obra que a indústria da mídia tradicional, o que aumentaria a margem de lucro das empresas de tecnologia, que poderiam produzir muito a partir de pouco. Mas, o que, de fato, elas produzem? Embora grande lucratividade seja atribuída a essas empresas, não é claro de que modo elas geram riqueza. A dificuldade de deduzir isso parte, na verdade, de um equívoco na forma de compreender o processo de geração de riqueza das mercadorias do conhecimento, bem como as transformações recentes na natureza do trabalho que as produz. No próximo item partiremos do exemplo empírico do modelo de trabalho criado pelas empresas do Vale do Silício para tentar entender o que ele produz e como as empresas auferem seus rendimentos da partir dele. Veremos que também nesse processo, a vida privada - dessa vez dos funcionários, e não apenas dos usuários desempenha papel fundamental.

\subsection{O trabalho nas empresas de tecnologia do Vale do Silício}

O escritório do Facebook em Menlo Park, Califórnia, é um conjunto de onze prédios, com loja de cupcakes, churrasqueira, sala de jogos eletrônicos, cafeteria, loja de doces, barraca de tacos, hambúrgueres, pizza, salada e mais

\footnotetext{
${ }^{206}$ OECD Statistics. Annual Labor Force Statistics. OECD total Civilian Labor Force 2000-2012.

${ }^{207}$ Glyn, Andrew. Imbalances of the Global Economy. New Left Review, 34, July August 2005, p.15.
} 
três pequenos restaurantes ${ }^{208}$. Tudo é de graça ou subsidiado pela empresa. A semelhança com um parque de diversões não é por acaso. Como no parque temático Magic Kingdom, ela é criada intencionalmente a serviço da "espontaneidade". Nenhum funcionário tem uma sala própria, apenas o próprio Mark Zuckerberg, que, às, vezes faz reuniões dentro de um grande cubo de vidro no meio do escritório. Portas são vistas como um impedimento à criação de algo novo.

O slogan não-oficial da empresa é "hack", um termo da engenharia que veio a significar "reconstruir algo com a desconsideração dos amadores pelas regras tradicionais"209. Os "all-nighters", como são chamados os funcionários que passam a noite trabalhando no escritório, são encorajados a terem sempre novas ideias antes que alguma start-up as tenha. Frases típicas são: "Correr riscos me dá energia", ou "O que você faria se não tivesse medo"; o mote é dado pelo mantra de Zuckerberg: "A jornada está 1\% finalizada".

No escritório há também lojas de madeira e impressão, que servem para os funcionários realizarem atividades "offline", incluindo projetos pessoais e impressão dos muitos pôsteres pregados pelo escritório. A companhia acredita que esse tipo de atividade os ajude a criar softwares mais amigáveis para 0 consumidor, além de os manter perto do escritório.

No Google, o pioneiro desse formato de trabalho, as refeições gratuitas oferecidas no escritório ficaram conhecidas por sua qualidade. Em um ambiente obcecado por informações, em que tudo é estudado nos mínimos detalhes, percebeu-se rapidamente que os funcionários gastavam muito tempo

\footnotetext{
${ }^{208}$ Hardy, Quentin. The Monuments of Tech, The New York Times. 1/03/2014.

${ }^{209}$ Idem.
} 
para almoçar fora do espaço de trabalho. Assim, para evitar que eles perdessem qualquer minuto a mais para encontrar uma refeição fora, decidiram rapidamente que a oferta de comida boa e gratuita seria a melhor solução para manter seus funcionários por perto.

Também descobriram que plantas dentro do escritório podiam diminuir o nível de estresse. Anthony Ravitz, lider do Green Team do Google afirmou "Nós estamos atrás do santo graal da indústria do conhecimento: como medir a produtividade. (...) "Isso não diz respeito apenas a quão rápido você é capaz de digitar, ou quão bem pode escrever um linha de código, mas sobre como você sentiu ao final dessas atividades, e se teve energia suficiente para brincar com os filhos quando chegou em casa"210. Para chegar a esses resultados, o Google Real Estate (a área de infra-estrutura da empresa) funciona como um laborátório que monitora de perto a experiência dos funcionários; as cadeiras do escritório, o tipo de iluminação e o aquecimento fazem parte dessa avaliações minuciosas. As salas passaram a aproveitar o máximo de luz natural possível, pois um estudo mostrou que a luz natural faz com que as pessoas aprendam e se curem mais rápido. Cada funcionário possui, também, uma cadeira com suas próprias medidas. O pressuposto por trás dessa atenção a todos os detalhes é o de que se as pessoas se sentirem mais confortáveis serão mais criativas e produtivas. A partir do mesmo princípio, essas empresas também investem em vasta área recreativa: piscina, sinuca, pebolim, pingue-pongue, vídeo-games, karaokê e eventuais drinks servidos às sextas-feiras são considerados extremamente importantes para aliviar o estresse e compensar as longas horas de trabalho requeridas. Para aqueles

\footnotetext{
${ }^{210}$ Idem.
} 
que não podem deixar a estação de trabalho, há, inclusive, uma esteira de exercícios físicos acoplada a um computador, para que seja possível fazer entrar em forma durante o trabalho. "Quanto mais duro trabalhamos, mais importante é ter um espaço para se afastar do caos por um tempo", diz Ravitz.

Como se não bastassem todas essas facilidades, existe ainda a possiblidade de trabalhar sem sair de casa. Essa prática tornou-se realidade para muitos trabalhadores, não apenas do setor das novas tecnologias da informação. As empresas entenderam que a flexibilidade deveria ser um princípio incorporado por elas próprias e passaram a oferecer essa possiblidade como uma "forma de reter os melhores trabalhadores"211. Essa flexibilização baseou-se em achados que confirmaram que aqueles que trocam a casa pelo escritório tendem a gastar mais horas dedicados ao trabalho e são, com frequência, mais produtivos. Porém, para que as chances de promoção não sejam comprometidas, o CEO da empresa Accretive Solutions recomenda que o funcionário saiba equilibrar as horas que passa em casa e no escritório, na medida em que a sociabilidade é muito importante para que o networking seja feito; afinal, "longe da vista, longe da mente".

Com tantas facilidades, essas empresas são consideradas os melhores lugares do mundo para se trabalhar ${ }^{212}$. A simulação do conforto da casa no ambiente de trabalho, com a colocação de redes, espaços para sonecas, refeições à vontade, e até a possibilidade de levar os animais de estimação ao

\footnotetext{
${ }^{211}$ Moran, Richard A. Is 'Working from Home' Another Big Work Lie?. Linkedin. 25/03/2014.

${ }^{212} \mathrm{Em} 2013$ e nos anos anteriores, o Google foi o primeiro da lista das 25 empresas que concorriam pela posição de "melhor lugar do mundo para se trabalhar" divulgada pelo instituto Great Place to Work.
} 
escritório, procura fazer com que o funcionário acredite que não haveria lugar melhor para estar do que ali.

Esse modelo de trabalho mostra que a divisão entre vida pessoal e trabalho nos primeiros estágios do capitalismo tinha uma limitação: ela estimulava o desejo do trabalhador de voltar para o conforto do lar. Se esse sentimento não foi um problema para o capitalismo florescente, no atual, ele foi percebido como um obstáculo à produtividade. Assim, na medida em que a casa perde sua função como refúgio, ou ambiente separado do trabalho, o trabalhador, ainda que possa voltar para ela no fim de sua jornada - embora as redes de descanso e a farta comida do escritório o incitem a ficar - não volta para o mesmo lugar que regressava no passado, já que, mesmo distante do escritório, o trabalho não o abandona.

Por outro lado, quando chega no escritório, o funcionário vê montada diante de si uma estrutura planejada nos mínimos detalhes para que seus sentimentos mais inefáveis possam se manifestar e serem devidamente apropriados. Assim, aquilo cujo cultivo era realizado nos momentos íntimos desfrutados na intimidade do lar, isto é, a criatividade, a engenhosidade, a devoção, as paixões e os desejos devem ser mobilizados e transformados em mercadorias. Não por acaso, como veremos, elas não podem ter o seu valor medido como uma mercadoria qualquer. 


\subsection{A apropriação do conhecimento como meio de produção: o trabalho material e imaterial}

O modelo de trabalho do Vale do Silício representa uma espécie de ápice do desenvolvimento de um tipo de trabalho cuja forma já vinha sendo pensada por alguns autores desde que as novas tecnologias da informação se firmaram como base da economia digital ou economia da informação. Nascimento (2006), por exemplo, ao percorrer a trajetória das formas de subsunção do trabalho ao capital, irá concluir que a última fase, representada pela apropriação do conhecimento em forma de ciência ao capital, constitui o estágio mais avançado que a subsunção pôde assumir nesse processo.

A apropriação do conhecimento como meio de produção, como mostra o autor, tornou-se clara, pela primeira vez, na manufatura ${ }^{213}$. Nela, não se tratava ainda da utilização da ciência como tal, mas sim, do conhecimento prático do trabalhador artesanal que, convertido em trabalhador parcial, teve seu saber apropriado para aumentar a força produtiva do capital. A ciência, de outro modo, ainda não fora convertida diretamente em meio de produção, mas aplicada para o desenvolvimento de técnicas de produção mais eficientes, já na fase da grande indústria.

Na manufatura, a dependência da produção em relação à habilidade humana criava gaps no processo produtivo, comprometendo sua unidade técnica. Com a introdução da maquinaria, esse problema foi resolvido, ajudando, inclusive, o capital a superar algumas barreiras constituídas pela

${ }^{213}$ Nascimento, 2006, p.103 
resistência do trabalhador, isto é, tentando impor sua vontade no desenvolvimento do processo produtivo ${ }^{214}$.

Na manufatura, a dominação do capital não modificou propriamente a constituição do trabalho, mas repousava, antes, sobre a força de trabalho materializada pelo próprio corpo do trabalhador. Na grande indústria, houve uma mudança radical no modo de produzir, derivada da introdução das máquinas. Nesse caso, a dominação do capital incidia diretamente sobre os meios de produção ${ }^{215}$. A introdução das máquinas não apenas criou uma nova base técnica para o processo produtivo, mas transformou a própria posição do trabalhador e a constituição do trabalho. Aparentemente libertador, por diminuir a dependência das limitações físicas do trabalhador, o surgimento da máquina fez com que o trabalhador fosse separado das ferramentas, para que estas fossem integradas à maquinaria. Houve, portanto, uma segunda desapropriação do trabalhador, pois, nessa fase, ele "não apenas deixa de ser o autor do produto final como já não executa sequer as próprias operações de trabalho, cabendo-lhe apenas supervisionar a ação da maquinaria e atuar como força motriz" ${ }^{216}$. Isto é, se antes ele ainda era autor das operações parciais de trabalho, na grande indústria, tornou-se um "apêndice da máquina", em um processo que enunciava o distanciamento do trabalhador do processo produtivo.

O ganho em produtividade, porém, foi notável, quando o elemento subjetivo que restava na manufatura foi suprimido e resolvido o problema da

\footnotetext{
${ }^{214}$ Marx, 1985, p.275

${ }^{215}$ Nascimento, 2006, p.109

${ }^{216}$ Idem, p.112
} 
cooperação entre processos parciais. Contudo, o efeito colateral do aumento da produtividade não foi a liberação do trabalho, mas o contrário: "Se a maquinaria é o meio mais poderoso de elevar a produtividade do trabalho, isto é, de encurtar o tempo de trabalho necessário à produção de uma mercadoria, ela se torna, como portadora de capital, o mais poderoso meio de prolongar a jornada de trabalho para além de qualquer limite natural"217 e, assim, baratear as mercadorias e encurtar o tempo de trabalho necessário, a fim de liberar sobretrabalho gratuito ao capitalista $^{218}$. Dessa forma, o próprio desenvolvimento da maquinaria exigiu a ampliação do campo de exploração do trabalho humano e do capital e criou condições para que ela acontecesse ${ }^{219}$.

$\mathrm{Na}$ fase posterior à grande indústria, a ciência, antes somente aplicada ao processo de produção, passou a atuar diretamente nele, por meio da produção de tecnologias novas, patentes, etc. Nesse estágio, o capital, livre das constrições representadas pela materialidade dos corpos físicos e mecânicos, pôde ampliar a subsunção do trabalho, para apropriar-se das qualidades mais inefáveis dos seres humanos: seu pensamento, sua capacidade criativa, sua intimidade. O próprio capital perdeu seu corpo material nesse processo e adquiriu uma forma imaterial, assim como o trabalho. O que cada uma dessas fases (maquinaria, indústria e conhecimento) evidencia, segundo Nascimento, é a tendência do capital a ampliar seu campo de dominação, invadindo cada vez mais esferas de atividade social.

\footnotetext{
${ }^{217}$ Marx, 1985, p.28

${ }^{218}$ Idem, p.7

${ }^{219}$ Ibid., p.23
} 
Para os filósofos Hardt e Negri (2001), esse tipo de trabalho, chamado de "imaterial", seria caracterizado principalmente pelas atividades dos novos setores tecnológicos, e também teria sido resultado das demandas de 1968 por flexibilidade, criatividade, consideração do mérito individual, fim das rotinas e da disciplina rígida de trabalho, etc. Esse teria sido o momento crucial da expansão do capital para subsumir todos os aspectos da produção e reprodução social, isto é, sobre todas as esferas da vida, bem como da grande influência das relações culturais sobre processos e estruturas econômicas de valor. Um novo regime de produção e, sobretudo, um novo regime de subjetividade estaria sendo criado.

$\mathrm{Na}$ fase da "pós-modernização econômica" ou "informatização"220, a atividade econômica central seria constituida pelo provimento de serviços e a manipulação de informação. Nesse estágio, toda a produção econômica, incluindo a industrial, deveria submeter-se à dominação da economia informacional e ser qualitativamente transformada por ela ${ }^{221}$. A novidade da informatização seria o fato de ela estar imbricada e ser imanente ao novo processo produtivo, no qual a informação e a comunicação seriam as verdadeiras mercadorias produzidas, e a rede constituiria o próprio sítio da produção e da circulação.

O "trabalho imaterial" é assim definido, na medida em que resulta em bens não-duráveis e imateriais, tais como serviços, produtos culturais, conhecimento ou comunicação ${ }^{222}$. Outra característica fundamental é sua

\footnotetext{
${ }^{220}$ Hardt e Nedri, 2001, p.280.

${ }^{221}$ Idem, p.281.

222 Ibid. p. 290.
} 
analogia com o computador: este pode continuamente modificar suas práticas e operações no desenrolar dos processos, tendo por base a interação com 0 usuário e com o ambiente. Citando Robert Heicht, os autores dizem que tais funções foram denominadas como "serviços analítico-simbólicos", que envolvem "solução e identificação de problemas, atividades de mediação

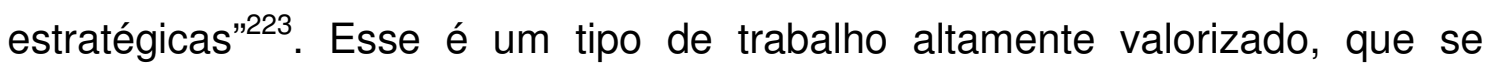
tornou a chave para a competição na nova economia global e é também a encarnação do trabalho em sua forma mais abstrata: todas as atividades irão exigir basicamente as mesmas funções de manipulação de simbolos e informação 224 .

Porém, existe outra face do trabalho imaterial que não segue as regras do modo de informação, a saber, o trabalho afetivo, o care, cujo centro é a interação e o contato humano. Mais do que uma forma imaterial computadorizada, esse é um tipo de produção de mais-valia que "toma a forma de interatividade cooperativa mediante redes linguísticas, comunicacionais e afetivas". Esse trabalho seria produtor de redes sociais, formas de comunidade e biopoder 225

Os aspectos mais centrais do trabalho imaterial, ao ver dos autores, são a interação social e a cooperação. Assim, a produtividade, a geração de riqueza e mais-valia social tomariam a forma da interatividade cooperativa, mediante redes comunicacionais e afetivas ${ }^{226}$. Nesse sentido, concluem os autores que o trabalho imaterial teria o potencial para instaurar uma nova forma

\footnotetext{
${ }^{223}$ 2001, p.292

224 Idem.

${ }^{225}$ Ibid., p.293

${ }^{226}$ Ibid., p.294.
} 
de comunismo, espontâneo e elementar. Na medida em que participamos de um mundo produtivo composto por redes sociais e comunicacionais, e nossa realidade social e econômica é definida menos pelos objetos materiais do que pelos serviços e relações que são cooperativos e coproduzidos, o próprio conceito de propriedade privada estaria tornando-se obsoleto. Seguindo esse raciocínio, o avanço das forças produtivas teria se desenvolvido a tal ponto que a produção de riqueza (valores de uso) não dependeria mais da exploração do trabalho abstrato. Este, desse modo, estaria emancipado da própria subsunção ao capital. Sendo minadas suas bases (subsunção do trabalho e propriedade privada), o próprio capital se enfraqueceria como forma social, daí o comunismo espontâneo mencionado pelos autores.

Maurizio Lazzarato (1996), o primeiro a desenvolver a ideia de "trabalho imaterial", também acredita que essa forma de gestão cria riscos para o capital, uma vez que sua própria existência está nas mãos de uma força de trabalho convocada a exercer sua criatividade mediante esforços coletivos. Entretanto, discorda de Hardt e Negri quanto ao seu caráter libertador em relação à subsunção ao capital. Para ele, assim como para Nascimento (2006), o regime de gestão do trabalho imaterial, ao cobrar do trabalhador que dê o máximo de suas capacidades intelectuais, revela-se ainda mais totalitário que a rígida divisão anterior entre trabalho mental e manual, já que o capitalismo procura envolver até mesmo a personalidade e a intimidade do trabalhador na produção de valor.

Entretanto, para todos esses autores, o trabalho imaterial constitui uma forma predominante do novo estágio do capitalismo que tenderia a se impor sobre as formas "obsoletas" e tradicionais, características da grande indústria. Isto os levou a pensar que o tempo de trabalho socialmente necessário para a 
produção das mercadorias deixaria de ser a medida do valor, isto é, conforme o trabalho se torna cada vez mais complexo e qualificado, e cada vez mais indistinto do tempo livre, o valor não pode mais ser calculado. Nesse caso, a exploração do trabalho permaneceria, mas fora de qualquer medida econômica. Sua realidade econômica seria fixada exclusivamente em termos políticos.

Eleutério Prado (2005) também propôs que o processo de valorização na pós-grande indústria, cuja base seriam as mercadorias do conhecimento, teria a mesma forma do rendimento do capital financeiro, isto é, os juros, o que contribuiria para uma "desmedida do valor". Para ele, assim como para Fausto (1989), "o advento da pós-grande indústria teria modificado a substância do valor, que antes era o tempo de trabalho e agora, cada vez mais, seria devida ao avanço do conhecimento, que se dá no tempo de não-trabalho"227. Em suas palavras,

"A pós-grande indústria projeta um modelo limite de empreendimento capitalista: empresas sem fábricas, ou seja, empresas que concentram apenas as atividades financeiras e as atividades de pesquisa e de criação de bens culturais, científicos e tecnológicos, ou seja, daqueles valores de uso que, sob a forma de mercadorias, podem receber a forma de capital de empréstimo. Os ativos desse tipo de empresa consistem, então, apenas em dinheiro, títulos públicos e privados, ações, assim como direitos de propriedade intelectual. Rigorosamente, essa empresa não produz e não vende diretamente mercadorias do modo ordinário; ela comercializa o direito de acesso às suas patentes, direitos autorais, marcas, projetos e processos de produtos, etc., que não são mais do que mercadorias que funcionam como capital”228.

Na medida em que ciência e tecnologia são bens essencialmente sociais e públicos, elas não podem ser vendidas como mercadorias stricto sensu.

\footnotetext{
${ }^{227}$ Cf. Teixeira, p, 423

${ }^{228}$ Prado, 2005, p. 109
} 
Afinal de contas, quando alguém compra uma máquina, por exemplo, esta não pode ser facilmente reproduzida, pois seu custo de reprodução depende de grandes somas de trabalho e investimento monetário. Um software, por outro lado, ainda que para sua produção original tenham sido despendidas várias horas de trabalho e grandes somas de recursos em laboratórios, equipamentos, etc, o tem o custo da reprodução de sua cópia quase nulo, bastando a transmissão dos dados para um suporte adequado (CD, pendrive, disco rígido, etc), de custo ínfimo. Se o que compõe o valor de um mercadoria, de acordo com Marx, é o tempo de trabalho socialmente necessário para sua reprodução $0^{229}$ o valor desse tipo de mercadoria só pode ser nulo, já que, para a sua reprodução é apenas necessário o tempo para reproduzir o substrato material no qual são materializadas. Nesse sentido, procurar o valor dessas mercadorias, tal como se faz como uma mercadoria tradicional, só pode induzir a erro 230 .

De que modo então, os proprietários dos softwares podem obter rendimento a partir deles? Isso ocorreria por meio da venda dos direitos de uso que mantêm, mediante um contrato que garante sua propriedade monopolista. Nesse sentido, ao vender essas licenças, tais empresas atuariam como aquelas que alugam dinheiro e seu rendimento teria forma dos juros ${ }^{231}$.

\footnotetext{
${ }^{229}$ Marx, K. O Capital, Livro III, Tomo I, 1985, p. 298

${ }^{230}$ Haddad (1998) também concorda que "a atividade inovadora, ao contrário do trabalho qualificado, não produz valor. A internalização da ciência ao processo produtivo por meio da contratação, pelo capital, de agentes inovadores, não muda o fato de que, por exemplo, o 'custo de concepção' de uma nova mercadoria não se confunde com o 'custo', medido em trabalho social, de reproduzi-la industrialmente, que é a única medida de seu valor. Sem dúvida, o resultado da atividade de pesquisa e desenvolvimento se incorpora às mercadorias. Mas ela não é uma atividade produtiva, no sentido exato da palavra. Ela não produz mercadorias, embora funcione como promotora do aperfeiçoamento do processo de produção de mercadorias." (p. 25)

${ }^{231}$ Prado, 2005.
} 
Para Teixeira ${ }^{232}$, porém, embora a caracterização das mercadorias do conhecimento feita por Prado seja correta, o rendimento auferido a partir delas não tem a mesma natureza que o dinheiro que se torna juros. As mercadorias conhecimento, na medida em que não portam valor, não podem tornar-se capital possível, tampouco capital portador de juros, pois, ao serem comercializadas pelo proprietário para serem utilizadas no processo produtivo, elas são cedidas não como valores (que é nulo ou quase nulo), mas como valores de uso, como capital-mercadoria. São, portanto, meios de produção, mercadorias cujo valor de uso é auxiliar na produção de novos valores de uso.

Teixeira propõe que a renda obtida a partir das mercadorias do conhecimento é da mesma natureza que a renda da terra definida por Marx ${ }^{233}$. Este, para construir sua definição, compara a produtividade das máquinas a vapor e das quedas d'água. Em seu exemplo, devemos supor que a maioria das fábricas num país seja impulsionada por máquinas a vapor, e uma minoria o seja por quedas-d'água naturais. Os capitalistas que utilizam a queda d'água têm um preço de produção mais baixo. Como a maioria utiliza as máquinas a vapor, os que utilizam a queda d'água se beneficiarão de um preço individual de produção menor que o preço social (baseado nas máquinas) e obterão um sobrelucro por conta dessa diferença.

\footnotetext{
232 2009, p.434.

233 “O pressuposto no modo de produção capitalista, portanto, é o seguinte: os verdadeiros agricultores são assalariados, empregados por um capitalista, o arrendatário, que exerce a agricultura apenas como campo específico de exploração do capital, como investimento de seu capital numa esfera específica da produção. Esse capitalista-arrendatário paga ao proprietário da terra, ao proprietário do solo explorado por ele, em prazos determinados, por exemplo anualmente, uma soma em dinheiro fixada contratualmente (assim como o mutuário paga juros determinados pelo capital monetário) pela permissão de aplicar seu capital nesse campo específico de produção. A essa soma de dinheiro se denomina renda fundiária, não importando se é paga por terras cultiváveis, terreno de construção, minas, pesqueiros, matas etc. Ela é paga por todo o tempo durante o qual o dono da terra emprestou, alugou o solo ao arrendatário. A renda fundiária é aqui, portanto, a forma em que a propriedade fundiária se realiza economicamente, se valoriza" (Marx, L. III, T. II, 1985, p. 126).
} 
Para Marx, o fabricante, nesse caso, deve seu sobrelucro à própria diferença constitutiva entre a natureza e as máquinas. "A força motriz da queda d'água encontra-se na Natureza e não custa como o carvão, que, sendo ele próprio produto do trabalho, precisa ser pago como um equivalente, mas transforma, do mesmo modo, água em vapor. A queda d'água, por outro lado, é um agente natural da produção e em sua criação não entra nenhum trabalho"234. A pergunta-chave, portanto, é a seguinte: "Se forças naturais estão disponíveis para todos, de onde vem então a especificidade da situação do capitalista que emprega a queda-d'água?" A resposta é que a "a queda-d'água é uma força natural monopolizável". Além disso, é uma força que "não é produtível mediante determinados investimentos de capital". Ou seja, a terra não pode ser reproduzida. De que modo, portanto, o sobrelucro se converte em renda fundiária? Como explica Marx:

"Imaginemos agora as quedas-d'água, com as terras a que pertencem, nas mãos de pessoas que são consideradas proprietárias dessa parte do globo terrestre, como proprietários fundiários, e que resolvam excluir o investimento do capital na queda-d'água e sua utilização como capital. Elas podem permitir ou negar a utilização. Mas o capital não pode criar por si a queda-d'água. $O$ sobrelucro que se origina dessa utilização da queda-d'água não se origina, portanto, do capital, mas do emprego de uma força natural monopolizável e monopolizada pelo capital. Nessas circunstâncias, o sobrelucro se transforma em renda fundiária, isto é, recai para o proprietário da queda-d’água."

Teixeira realça que, a partir do momento em que as circunstâncias especiais que geram sobrelucro passam a ser produzidas pelo capital, o conhecimento, antes livre e disponível a todos, passa a ser monopolizável, tal como a terra. Em outros termos, quando a produção de conhecimento passa a

${ }^{234}$ Idem, p. 143 
ser realizada como produção capitalista, os produtores de tal conhecimento só o produzirão se puderem auferir privadamente os ganhos dele derivados ${ }^{235}$.

É desse modo, ao ver do autor, que os direitos de propriedade intelectual, patentes e direitos autorais podem garantir, de forma permanente ou duradoura, a existência de sobrelucros para o capitalista que dispõe de seu valor de uso, tal como para aquele que dispõe da queda d'água no exemplo de Marx. Essa também seria a origem do alto preço cobrado por essas mercadorias. Embora, como já explicamos, elas tenham valor nulo, o direito de propriedade do conhecimento, sendo monopolizável, permite ao proprietário cobrar um alto preço pelo direito de uso. Em suma, ele receberá uma parcela do produto social em retribuição pela concessão do uso de seu conhecimento. A renda do conhecimento será constituída, portanto, desse modo.

Ora, como se determina essa renda, pergunta-se o autor. Da mesma forma que a renda da terra, como renda diferencial. Do mesmo modo que no exemplo da queda d'água de Marx, a posse de um conhecimento especial/inovador/único por um determinado capitalista faz com que o preço individual de sua mercadoria seja menor que o preço social de produção, permitindo-lhe obter sobrelucro. Assim como esse sobrelucro se metamorfosearia em renda da terra no caso da queda d'água, neste, se transformará em renda do conhecimento. Portanto, tanto a renda da terra quanto a renda do conhecimento provêm do monopólio e ambas podem aumentar a a força produtiva do trabalho.

235 2009, p. 438. 
Desse modo, o autor discorda de que, com a aplicação mais intensiva da ciência na produção, a substância do valor tenha mudado, não seja mais possível medi-lo, ou ainda que sua medida não seja mais o trabalho. Embora tenham havido significativas transformações no processo produtivo e nas formas de subsunção do trabalho ao capital, elas não alteraram a substância do valor ou a fonte desse valor, isto é, o próprio trabalho.

O próprio Marx, como nota o autor, pensou, hipoteticamente, na possibilidade de existirem valores de uso que pudessem ser produzidos sem trabalho e que, tal como a terra, tivessem o valor de uso de aumentar a força produtiva do trabalho. Mas estes não teriam valor de troca, apenas valor de uso. Essa possibilidade hipotética tratada por Marx é exatamente o caso da mercadoria conhecimento. A única diferença formal dessa mercadoria conhecimento com relação à terra é o fato de ela ser reprodutível (não o conhecimento em si, como vimos, mas o substrato material que o transporta), e reprodutível sem dispêndio de tempo de trabalho, ou com um dispêndio exíguo. A conclusão de Teixeira é que os desvios e as dificuldades para compreender de que modo as mercadorias conhecimento produzem riqueza vem do fato de que estas criam redistribuições do valor ainda gerado pelo trabalho abstrato. Conforme ele explica:

Estes desvios significam simplesmente redistribuições do valor gerado e jamais representam criação de valor por outra fonte que não o tempo de trabalho abstrato. O que se pode dizer é que, sendo a produção e circulação das mercadorias conhecimento responsável por uma parcela cada vez mais importante do processo de valorização capitalista, e sendo que tais mercadorias alcançam preços muito acima do que se justificaria pelo tempo de trabalho necessário à sua reprodução, tais desvios se tornam cada vez mais acentuados. Assim, se ao falarmos em desmedida estivermos nos referindo 
apenas a desvios de preços com relação a valores, então ela não é um fenômeno novo e característico apenas do capitalismo contemporâneo, embora a proeminência obtida pelas mercadorias conhecimento possa acentuar tais desvios ${ }^{236}$.

Para tornar o argumento mais concreto, imaginemos de que modo a empresa Nike, hoje, vende seus tênis. Sua base produtiva localiza-se em países da Ásia e da América Central. Lá é gerado o valor da mercadoria, a partir do tempo de trabalho dos operários que fabricam os calçados. Dali em diante, a mercadoria é distribuida aos varejistas para ser vendida. Em seu processo de circulação, da linha de produção até o destino final nos pés do consumidor, é necessário que uma longa cadeia de serviços seja mobilizada: o consultor financeiro da empresa, o designer dos modelos e as agências de publicidade que irão definir sua estratégia de marketing. Todo esse trabalho envolve a produção de mercadorias conhecimento: design, propaganda, consultoria, etc. Esses serviços, embora fundamentais para que o tênis seja vendido, não produzem, contudo, seu valor. Seu papel, nessa cadeia, é promover a redistribuição do valor gerado originalmente na indústria. No final do processo, o alto preço alcançado pelo tênis Nike pode não ser mais reflexo direto do valor produzido em sua fabricação devido à impossibilidade de medir o valor do trabalho imaterial que é realizado em sua circulação, mas isso constitui apenas uma distorção do preço em relação ao valor, e não distorção do valor em si.

Mas, onde entraria a Internet e as redes sociais nesse processo? Se já sabemos que elas não são capazes de gerar valor, de que modo, então, elas geram riqueza a partir das informações pessoais das pessoas? E qual é a

${ }^{236}$ Teixeira, 2009, p.455 
relação entre o lucro dessas empresas e a produção "tradicional" de mercadorias?

\subsection{A apropriação da informação pessoal pelo capital}

Twitter's and Facebook latest models for making money still seem to me like one part pyramid scheme, one part wishful thinking, and one part repugnant panoptical surveillance Jonathan Franzen

Recentemente houve a notícia de que o número de usuários do Facebbok havia caído, principalmente entre adolescentes. Entretanto, apesar dessa queda, os executivos da empresa asseguraram que o lucro com a venda de anúncios teria aumentado no mesmo período. Como observa Vauhini Vara ${ }^{237}$, por um longo tempo, o Facebook procurou convencer os especialistas em marketing que os anúncios exibidos em suas páginas eram úteis, isto é, que seriam capazes de ajudar os produtores a venderem suas mercadorias. Agora, de acordo com a chefe de operações da empresa, Sheryl Sandberg, o trabalho de convencimento não é mais necessário. A rede social possui dados que provam que há um retorno específico e significativo para os investimentos em anúncios em seu news feed. "Nosso objetivo é obter, de modo não invasivo à privacidade, todas as informações que pudermos sobre o que os consumidores querem e oferecer esses dados aos profissionais de marketing, para que os usuários tenham uma experiência positiva com os anúncios", disse Sandberg, sejam essas informações obtidas por meio das "curtidas", de sua atividade em outros sites, ou afirmações

\footnotetext{
${ }^{237}$ What you're worth to Facebook. The New Yorker. 30 de Janeiro de 2014.
} 
contextuais feitas nas atualizações de status. Em síntese, por ter um registro detalhado das atividades, interesses e desejos das pessoas, o Facebook pode mostrar anúncios certeiros aos usuários, ou mesmo antecipar o que eles possam vir a desejar. Se, antigamente, o vendedor tinha grande trabalho para encontrar seu cliente, hoje, essa procura em tese acabou. Com todas as informações disponíveis nas redes sociais, é possível oferecer a mercadoria para quem já a procura, aumentando as chances de sucesso na venda. Os pioneiros da publicidade, que se esforçavam em desvendar os desejos dos consumidores, jamais poderiam imaginar que um dia seria possível até mesmo antecipar esses desejos antes que o próprio comprador deles se desse conta. É muito provável que alguém que esteja começando uma atividade física esteja à procura de um tênis e trajes esportivos, por exemplo. E esse é o tipo de informação largamente disponível no Facebook, pois se tornou costume de muitos usuários revelarem com detalhes suas práticas de exercícios físicos. Antes que o próprio esportista iniciante vá em busca da mercadoria, esta vem até ele, aproveitando o contexto extremamente favorável para que a compra se efetive.

Tal estratégia parece estar funcionando muito bem até o momento. $\mathrm{O}$ rendimento por usuário aumentou, em média, de U\$1.54 no ano passado para U\$ 2.14 neste $a^{238}$. Sandberg, antiga executiva do Google, não por acaso transportou a mesma estratégia de sucesso das gigantes das buscas na Internet para a rede social.

Tomando por base a explicação de Teixeira acerca da renda do conhecimento, é possível entender o papel central que a informação pessoal desempenha na estratégia de negócio das grandes empresas de tecnologia. Essa

\footnotetext{
${ }^{238}$ Idem.
} 
estratégia consiste basicamente no seguinte esquema: elas oferecem serviços online gratuitos, tais como email, comunicadores instantâneos, ferramentas de busca, organizadores de informação, jogos, aplicativos diversos, redes sociais, e mais uma infinidade de tipos de serviços pelos quais aparentemente não se paga, ou se paga muito pouco. Porém, para utilizá-los, o usuário deve aceitar fornecer uma série de informações pessoais que serão coletadas pela empresa. A quantidade coletada e o modo como a coleta é feita vai depender de cada serviço. Tomemos como exemplo o Google Now, produto da empresa Google. Com o objetivo de oferecer informações relevantes e atualizadas ao usuário, tais como a situação do trânsito no trajeto para casa, o tempo de viagem de um local a outro, as opções de transporte, atualizações de vôos, restaurantes próximos e etc, o serviço vale-se de toda a informação pessoal que puder coletar nos dispositivos móveis que o habilitarem, tais como localizações do usuário, histórico de buscas na web, contatos, compras realizadas, até viagens feitas, incluindo quais foram os vôos tomados, os itinerários realizados e a companhia aérea utilizada. Assim, se alguém buscar, por exemplo, uma farmácia em seu bairro, o Google now irá mostrar em primeiro lugar nos resultados aquelas que possuem anúncios patrocinados pela empresa e, depois, as demais que puder encontrar nas redondezas, com site, telefone e endereço. Essa foi a melhor maneira descoberta para exibir os anúncios patrocinados de modo relevante, pois não há nada melhor do que fazer propaganda de farmácia para quem já está buscando uma.

Portanto, para lançar mão da conveniência que a tecnologia pode oferecer, é efetuada a troca de informações pessoais pelos serviços online. Até esse ponto não dissemos nenhuma novidade. As políticas de uso dos sites são 
bastante explícitas no que diz respeito à utilização que fazem dos dados dos usuários. A questão é compreender de que modo as informações podem gerar, se não valor, riqueza para essas empresas.

Sigamos com o exemplo do Facebook. Para fazer parte da rede social, eu devo assinar um contrato no qual aceito ceder minhas informações pessoais para serem utilizadas pela empresa e terceiros, sob determinadas condições. A informação pessoal, como mercadoria do conhecimento, não tem valor, pois o custo social de sua reprodução é nulo. Isto é, uma vez em posse do Facebook, ele pode reproduzi-las sem nenhum custo a terceiros. Portanto, o Facebook se vale de uma "condição especial": o fato de ter o monopólio das informações pessoais ali inseridas pelos usuários, para utilizá-las de modo a oferecer com eficiência os anúncios de outras empresas e ajudá-las a vender suas mercadorias.

Em primeiro lugar, é preciso frisar: ao ceder essas informações, os usuários deixam de ser seus proprietários. Logo, a afirmação feita pelo Facebook de que "embora você esteja nos permitindo usar as informações que recebemos sobre você, você sempre será o proprietário de todas as suas informações", é incorreta. Ao tornar-se proprietária das informações cedidas em troca dos serviços, a rede obtém direito de uso sobre elas a partir de um contrato (os termos de uso), que garante sua propriedade monopolista dos dados.

Voltando ao exemplo da queda d'agua, se o capitalista que tem a propriedade monopolista sobre ela consegue um preço menor por conta da vantagem competitiva que os custos menores da força da natureza lhe proporcionam, a rede social, por ser a única detentora das informações (e não 
os usuários), adquire vantagem competitiva por poder oferecer publicidade com muito mais precisão e a um custo muito mais baixo (em comparação ao preço social da propaganda tradicional), já que, assim como a queda d'água é uma dádiva da natureza, a informação pessoal é produzida sem custo algum pelo usuário. De qualquer modo, a renda diferencial obtida pela apropriação das informações pessoais produzidas por milhões de usuários, ainda que descontados os custos com servidores e mão-de-obra dos funcionários da empresa, permite ao Facebook um grande sobrelucro em relação às mídias tradicionais. Essa renda, portanto, não advém do valor produzido pela empresa, ou do valor contido nas informações que são exploradas por ela, mas sim, da redistribuiçao do valor gerado em outros setores (por exemplo, do tênis Nike produzido na China e que será anunciado nas páginas dos usuários da rede social). Ou seja, no final do processo, ainda é o valor produzido pelo trabalho abstrato tradicional que gera a renda apropriada pelo Facebook e outras empresas do mesmo segmento, não havendo, portanto, nenhuma mágica, truque, ou desmedida que a esconda, ou que distorça qualquer economia. Porém, para se apropriar desse valor, é necessário mobilizar o trabalho imaterial de milhares de trabalhadores. 


\section{Conclusão}

Os desenvolvimentos recentes das novas tecnologias da informação transformaram de diversas formas o cotidiano, as formas de sociabilidade, de comunicação e os negócios. Alguns desses impactos foram festejados como formas de "empoderamento" da sociedade civil no sentido de que a Internet teria fortalecido o poder de organização de movimentos sociais, ampliado os canais de discussões políticas e dado espaço para vozes dissonantes se manifestarem. Por outro lado, essas novas tecnologias também se materializaram como ferramentas sofisticadas para coleta, armazenamento e disseminação de dados, assim como permitiram que uma massa inédita de informações pessoais fosse tornada disponível em âmbito virtual.

O assédio à informação pessoal, também, nunca foi tão grande quanto no presente; entidades políticas definem suas estratégias geopolítcas a partir da intercepção massiva de dados, como o escândalo de Edward Snowden revelou, e as empresas, detentoras de grande volume de dados de usuários de seus serviços, parecem não apenas cooperar com essas iniciativas, mas também extrair grandes lucros a partir da coleta das informações pessoais. Assim, as novas tecnologias da informação e, principalmente, a Internet passaram a ser vistas como as maiores ameaças contemporâneas à privacidade.

Na primeira parte da pesquisa, procuramos conhecer quais são, de fato, essas ameaças. Vimos que não é preciso imaginar nenhum tipo de roteiro hollywoodiano de intrigas complexas para entender o que ocorre quando a privacidade recua: reputações destruídas, empregos perdidos, relações 
rompidas e uma série de outros problemas que são suficientes para arruinar vidas.

Com todo esse assédio sobre a informação pessoal e os recorrentes escândalos sobre as ações de vigilância de governos, é de se espantar, sobretudo, que as pessoas não apenas continuem a se expor nos ambientes virtuais, mas que jamais tenham se exposto tanto. Seriam apenas as novas tecnologias as responsáveis pelo aumento da exposição da vida privada e por todos os conflitos que a decadência da privacidade engendrou, bem como pela transformação da vida privada em mercadoria? Nossa suspeita era a de que a introdução da nova tecnologia no cotidiano teria apenas facilitado e acelerado uma tendência que se vinha observando no momento em que se afirma o terceiro espírito do capitalismo: a vida pessoal estaria fadada a perder a proteção e a obscuridade oferecidas pelas quatro paredes do lar e entrar na cena pública, e desse modo, ela poderia ser diretamente subsumida pelo capital. Portanto, seria necessário voltar a atenção para as transformações dos sentidos que a vida privada adquiriu em sua relação com o sistema capitalista ao longo do tempo.

Desse modo, foi visto que os burgueses do século XIX, inventores da privacidade, possuíam um modo de vida em que a família e a casa eram claramente separadas do mundo profissional, como esferas de vida distintas. Cada um desses âmbitos correspondia a papéis sociais, valores e códigos próprios. Ao sair de casa, tanto o burguês quanto o trabalhador se preparavam para enfrentar o tumulto do mundo público constituído pela cidade, com seus perigos e tentações. Esse arranjo fazia muito sentido numa época em que a casa havia recentemente perdido sua função produtiva e a progressiva 
racionalização do trabalho, ameaçando transformar os homens em máquinas, podia ser compensada pela proteção que, agora chamada de "lar", ela deveria oferecer. Se o mundo do trabalho nunca havia sido tão duro e frio, a intimidade vivenciada na esfera doméstica poderia oferecer um anteparo considerável às durezas da vida. Portanto, em seu início, a constituição da privacidade como direito foi essencial para a proteção de uma nova esfera da vida, ligada ao reconhecimento da subjetividade e da personalidade como dotadas de valor intrínseco.

Entretanto, já em seus primórdios, a privacidade aparece como dotada de uma ambiguidade fundamental; já havia, nesse tempo, a percepção de que a esfera privada e seus produtos - as ideias, a criatividade e as informações privadas - além de seu próprio valor intrínseco, poderiam gerar valor monetário. Porém, havia também o desejo, claramente manifesto, de que a esfera da vida ligada a esses sentimentos fosse protegida das interferências externas. Assim, embora esses dois sentidos estivessem imbricados na origem da privacidade, a proteção daquilo que se desenrola na esfera doméstica visava garantir a existência da intimidade e a imunidade desse âmbito da vida em relação ao mundo exterior do trabalho, da produção e do espaço público em geral.

Como mostrou Simmel, o segredo é necessário para distinguir relações triviais e não-triviais. O que confere o caráter especial de uma relação é o fato de que ela se dá somente entre determinadas pessoas e mais ninguém. Esse era, portanto, o sentido mais profundo da valorização burguesa da privacidade, isto é, o reconhecimento de que, para existirem relações especiais, certa esfera de segredo seria necessária. Por isso, a despeito da incipiente valorização 
monetária de algumas derivações da vida pessoal já observadas naquela época, havia uma insistente proteção da esfera privada por conta da importância conferida pelos burgueses a essas relações íntimas.

Na fase que marca o segundo espírito do capitalismo, a separação entre vida privada e pública parece ainda mais acentuada com a prevalência do mundo burocratizado, no qual trabalho e vida doméstica são rigidamente separados e a última é considerada como o âmbito maior de realização pessoal, mediada pelo consumo de mercadorias. Contudo, a penetração do consumo na esfera doméstica também possibilita entrever que já há, nesse momento, uma aproximação maior entre vida privada e capitalismo.

$\mathrm{Na}$ passagem para o terceiro espírito, entretanto, já é possível visulumbar o início do fim da separação entre público e privado. Nesse período, a popularização das novas teorias de gestão e a valorização do "capital humano" dos trabalhadores, isto é, suas emoções, sua personalidade, sua criatividade e etc., mostram como a transformação de valores ocorrida no período permite que se torne aceitável e socialmente legítima a premissa de que, dali em diante, seria possível extrair dividendos de uma esfera da vida antes considerada "sagrada". Vista em sua forma mais desenvolvida nos escritórios das empresas do Vale do Silício hoje, a junção entre vida pessoal e trabalho foi um passo decisivo para que se fizesse a incorporação total da primeira pelo capital. Já presente na esfera produtiva, bastou apenas um passo além para que a vida pessoal passasse a gerar valor diretamente, tornando-se mercadoria.

Ao longo dos anos 70 e 80, entretanto, a absorção da vida privada pelo processo produtivo começa a mostrar suas primeiras consequências: os 
indivíduos, estimulados a voltarem-se para o desenvolvimento de seus recursos interiores, desinteressam-se da politica. O contexto da falência do Estado de Bem-Estar social e da ausência de respostas políticas aos problemas sociais fez com que a descrença fosse canalizada para a busca de soluções individuais e psíquicas: resta ao indivíduo lidar com as questões que a política não consegue mais responder. Cada vez mais solicitado e mais ávido de reconhecimento, ele vê diante de si uma grande demanda por melhorar o seu desempenho geral: a performance na vida pessoal é fundamental para uma boa vida profissional e vice-versa. Para isso, não reluta em recorrer aos mais diversos tipos de aconselhamento e expor os seus dramas pessoais na esfera da mídia. A partir daí, a exibição da vida privada parece adquirir cada vez mais vigor, principalmente com a ampliação dos canais para esse fim na Internet.

No entanto, há diferenças importantes na evolução desse fenômeno desde os anos 1980 até o presente. Para Alain Ehrenberg (1991), quem expunha a intimidade na televisão era o indivíduo incerto, desamparado pela política e à procura de resolução para seus problemas pessoais. Hoje, a exposição adquire novos sentidos: uma apresentação de si que reflita as qualidade prezadas pelo capitalismo conexionista assegura a ampliação das conexões, permite a conquista de um bom emprego, de bons relacionamentos e uma boa reputação, mas, sobretudo, pode ser diretamente convertida em ganhos monetários. Porém, quando a publicização da vida privada é malsucedida, são exatamente esses mesmos benefícios que o indivíduo vê se perderem, como vimos no primeiro capítulo da tese. 
A possibilidade de conversão direta da vida pessoal em dinheiro leva à assunção de que ela tenha se tornado uma mercadoria, e como tal, tenha adquirido valor. Porém, se é verdade que ela adquiriu o caráter de uma mercadoria sui generis, o mesmo não pode ser dito acerca de seu valor. No círculo de produção e circulação da informação pessoal, não há, como vimos, nenhum tipo de trabalho gerador de valor. Seu papel na atividade econômica é o de fazer, como qualquer outro tipo de mercadoria conhecimento, circular, ou redistribuir, o valor produzido nas esferas tradicionais de trabalho.

Desse modo, para retomarmos novamente o ciclo completo de apropriação da vida privada pelo capital, como primeiro momento, vemos o fim da separação entre trabalho e vida pessoal, permitindo que esta seja gradualmente incorporada ao sistema produtivo; a conversão da exibição da vida privada em mandamento do capitalismo conexionista é o segundo momento fundamental desse processo, já que permite que as informações pessoais exibidas sejam apropriadas pelas empresas de tecnologia e convertidas em ganho monetário.

Portanto, vivemos em um período no qual cada vez mais partes das vidas das pessoas deixam de ser ocultas. Além das imagens e revelações íntimas com as quais nos acostumamos nos domínios virtuais, é possível observar que a vida pessoal se tornou parte indissociável do mundo do trabalho, por meio da transformação da personalidade e de outros atributos pessoais em recursos produtivos. O passo final desse processo foi a tentativa de transformar a própria vida pessoal em mercadoria. 
Como insistiu Weber, a formação do capitalismo foi acompanhada por uma separação crescente entre a esfera doméstica e a esfera profissional| ${ }^{239}$, separação que para muitos define a própria essência do capitalismo. Entretanto, desde o final do século XX, a vida privada passou a ser integrada ao sistema capitalista com força cada vez maior, tanto por meio do trabalho (e do fim da separação entre vida pessoal e profissional), quanto por meio do próprio papel que a vida pessoal assume como realizadora de lucros. Essa integração é fundamental para compreender o destino da privacidade no mundo contemporâneo.

Diversos elementos que eram considerados propriedade do indivíduo foram, progressivamente, deixando de sê-lo nesse processo, na medida em que recua a fronteira que delimitava o espaço privado. Aparentemente, isso poderia ser um passo na direção de formas sociais mais livres, mais coletivas ou comunitárias, como imaginaram Hardt e Negri acerca do trabalho imaterial, ou como pensaram os idealizadores da Internet sobre os fluxos livres de informação. Entretanto, por trás dessa aparência, o que há é a expansão do capital em direção a espaços antes inabitados pela sua lógica: o lar, a intimidade, a personalidade, em uma palavra, a vida pessoal. Desse modo, o resultado mais veemente desse processo parece ser o seguinte: se não há mais um véu que esconda determinados aspectos da vida, eles podem ser diretamente subsumidos pelo capital. Resta saber se novos limites se interporão, ou se ele seguirá na mesma torrente por rumos ainda não imaginados.

\footnotetext{
${ }^{239}$ Weber, M. 1991, p. 261.
} 


\section{Bibliografia}

ALTMAN, Irving, Privacy Regulation: culturally universal or culturally specific? In: The Journal of Social Issues, vol. 33, 1977

ARIÈS, Philippe Introduction, in: A History of Private Life III, Belknap Press, 1993.

BARABÁSI, Albert-László. Linked: How Everything Is Connected to Everything Else and What It Means. Plume (Penguin Group). New York, 2003.

BAUERLEIN, Mark. The Digital Divide: Arguments for and Against Facebook, Google, Texting, and the Age of Social Networking. New York : Jeremy P. Tarcher/Penguin. 2011.

BAUMAN, Zygmunt. "Privacy, Secrecy, Intimacy, Human Bounds, Utopia - and Other Collateral Casualties of Liquid Modernity". In: Modern Privacy: Shifting Boundaries, new forms. BLATTERER, $\mathrm{H}$; JOHNSON, P; MARKUS, M. (eds.), Palgrave Macmillan, 2010.

BÉJAR, Helena. El ámbito íntimo (privacidad, individualismo y modernidad). Madrid: Alianza. Editorial, 1995.

BELLAH, R. N., MADSEN, R., SULLIVAN, W. M., SWIDLER, A., \& TIPTON, S. M. Habits of the heart: Individualism and commitment in American life. Berkeley, Harper Perennial,1985.

BENJAMIN, W. Charles Baudelaire: Um Lírico no Auge do Capitalismo. Obras Escolhidas III. Ed. Brasiliense, 1a.edição, 1989, p.33-65.

BEN-ZE'EV, A. (2003). Privacy, emotional closeness, and openness in cyberspace. Computers in Human Behavior, 19, 451-467.

BENNET, Colin J.. RAAB, Charles D., The Governance of Privacy: policy instruments in global perspective, Cambridge: The MIT Press, 2006

BLATTERER, Harry, JOHNSON, Pauline, MARKUS, Maria (eds.) Modern Privacy: shifting boundaries, new forms, New York: Palgrave Macmillan, 2010 
BOLTANKI, Luc, CHIAPELLO, Ève, O Novo Espírito do Capitalismo, trad. Ivone C. Beneditti, São Paulo: Martins Fontes, 2009

BOK, Sissela, Secrets: On the Ethics of Concealment and Revelation, New York: Pantheon Books, (1983).

BURKART, Gunter. When Privacy Goes Public: New Media and the Transformation of the Vulture of Confession. In: Modern Privacy: Shifting Boundaries, new forms. BLATTERER, H; JOHNSON, P; MARKUS, M. (eds.), Palgrave Macmillan, 2010.

CAIAFA, Janice, ELHAJJI, Mohammed (orgs.), Comunicação e Sociabilidade: cenários contemporâneos, Rio de Janeiro: Mauad, 2007

CAHALI, Yussef Said. Dano moral. $2^{\underline{a}}$ ed. rev., atual. e ampl.; $5^{\mathrm{a}}$ tir. São Paulo: Editora Revista dos Tribunais, 2000

CARR, Nicholas. The Big Switch: Rewiring the World, from Edison to Google, New York, 2008.

CASTELLS, Manuel, A Galáxia da Internet: reflexões sobre a internet, os negócios e a sociedade, trad. Maria Luiza X. de A. Borges, Rio de Janeiro: Jorge Zahar Editor, 2003

CAVALIERI Filho, Sérgio, Programa de Responsabilidade Civil, 7a. Edição, São Paulo: Editora Atlas, 2007

COMITÉ GESTOR DA INTERNET. Pesquisa sobre o uso das Tecnologias de Informação e Comunicação - TIC Domicílios 2010.

DEBATIN, Bernhard. Ethics, Privacy, and Self-Restraint in Social Networking. Privacy Online, 2011, p. 47-60

DUMONT, Louis. Homo Hierarquicus: O Sistema das Castas e Suas Implicações. Trad. Carlos Alberto da Fonseca. São Paulo, Editora da Universidade de São Paulo, 1992.

. O Individualismo: uma perspectiva antropológica da ideología moderna. Trad. Álvaro Cabral. Rio de Janeiro, Rocco, 1985.

EHRENBERG, Alain, L'individu Incertain, Calmann-Lévy, 1995 
EHRENBERG, Alain, O Culto da Performance: da aventura empreendedora à depressão nervosa, trad. Pedro F. Bendassolli, Aparecida: Idéias e Letras, 2010

EHRENBERG, Alain. The Weariness of the Self: diagnosing the history of depression in the contemporary age. McGill-Queen's University Press. Québec, 2010.

ELIAS, Norbert, O Processo Civilizador, trad. Ruy Jungmann, Rio de Janeiro: Jorge Zahar Editor, 1994, 2 vol.

ENGELS, Friedrich, The Condition of the Working Class in England, Penguin Books, 1987.

FEATHERSTONE, Mike; HEPWORTH, Mike; TURNER, Bryan S. The Body: Social Process and Cultural Theory. Sage Publications, London, 1991.

FAUSTO, Bóris, A História da Vida Privada no Brasil: contrastes da intimidade contemporânea, vol. 4. , São Paulo, Companhia das Letras, 1998.

FAUSTO, Rui. A pós-grande indústria nos Grundrisse (e para além deles). Revista Lua Nova, 19, 1989.

FRANZEN, Jonathan, The Corrections, London: Fourth State, 2010 , The Discomfort Zone: a personal history, New York: Farrar, Strauss and Giroux, 2006 Freedom, New York: Farar, Strauss and Giroux, 2010

FREUND, Paul, American Law Institute, 52nd Annual Meeting, (1975)

GARFINKEL, Simson. Database Nation: The Death of Privacy in the 21st Century. New York: O'Reilly Media, Inc.; 2000.

GAY, Peter. The Bourgeois Experience: Victoria to Freud . (Vol 1) "Education of the Senses". W. W. Norton \& Company, 1999

GERGEN, Kenneth. The Saturated Self: Dilemmas of Identity in Contemporary Life. New York: Basic Books, 2000.

GERSTEIN, Robert S., Intimacy and Privacy, in Philosophical Dimensions of Privacy 272, Ferdinand David Schoeman ed., 1984 
GERSHON, Ilana. Un-friend my heart: Facebook, Promiscuity, and a Hesrtbreak in a Neoliberal Age. Anthropological Quarterly, vol. 84, No. 4, 2011, p.865-894.

GOFFMAN, Erving. Estigma: Notas sobre a Manipulação da Identidade Deteriorada. Editora Guanabara, Rio de Janeiro, 1988. . Interaction ritual: essays in face-to-face behavior. New Brunswick, N.J.: Aldine Transaction, 2005.

A Representação do Eu na Vida Cotidiana. Tradução de Maria Célia Santos Raposo. Petrópolis, Vozes, 1985.

HABERMAS, J. A Mudança Estrutural da Esfera Pública. Tempo Brasileiro, 2003.

HAROCHE, Claudine, A Condição Sensível, trad. Jacy Alves de Seixas e Vera Avellar Ribeiro, Rio de Janeiro: Contra Capa, 2008

HONNETH, Axel. The Struggle for Recognition: The Moral Grammar of Social Conflicts. The MIT Press, Cambridge, Massachussets, 1995

ILLOUZ, Eva, Cold Intimacies: The Making of Emotional Capitalism, Cambridge: Polity Press, 2007

JOHN, Leslie K. and ACQUISTI, Alessandro and LOEWENSTEIN, George, The Best of Strangers: Context Dependent Willingness to Divulge Personal Information (July 6, 2009). Available at SSRN: http://ssrn.com/abstract=1430482 or http://dx.doi.org/10.2139/ssrn.1430482

JOHNSON, Pauline. Images of Intimacy in Feminist Discussions over Private/Public Boundaries. In: Modern Privacy: Shifting Boundaries, new forms. BLATTERER, H; JOHNSON, P; MARKUS, M. (eds.), Palgrave Macmillan, 2010.

KELLNER, Douglas, A Cultura da Mídia, trad. Ivone Castilho Benedetti, Bauru: EDUSC, 2001 
KIRKPATRICK, David, O Efeito Facebook: os bastidores da história da empresa que conecta o mundo, trad. Maria Lúcia de Oliveira, Rio de Janeiro: Intrínseca, 2011

KOJEVE, Alexander. Introdução à Leitura de Hegel: Aulas Sobre A Fenomenologia Do Espirito Ministradas de 1933 a 1939. Eduerj Contraponto, Rio de Janeiro, 2012.

KULLENBERG, Christopher. The social impact of IT: Surveillance and Resistance in Present-Day conflicts. Fltf Kommunikation, 01/09.

LASCH, Christopher, The Culture of Narcissism: american life in an age of diminishing expectations, New York - London: W. W. Norton \& Company, 1979

Haven in a Heartless World: the family besieged, New York - London: W. W. Norton \& Company, 1995 , The True and Only Heaven: progress and its critics, London: W. W. Norton \& Company, 1991

LIPOVESTKY, Gilles. A Era do Vazio. Tradução: Miguel Serras Pereira e Ana Luísa Faria. Lisboa: Editions Gallimard, 1983.

LOCKE, John, Two Treatises of Civil Government, London: Everyman's Library, 1966

LOPEZ-RUIZ, Osvaldo. O ethos dos executivos das transnacionais e o espírito do capitalismo. Tese de doutorado. Unicamp, 2004.

MACHADO, Marta Rodrigues de Assis; PÜSCHEL, F. P. ; RODRIGUEZ, José Rodrigo . The Juridification of Social Demands and the Application of Statutes: an Analysis of the Legal Treatment of Antiracism Social Demands in Brazil. Fordham Law Review, v. 77, p. 1535-1558, 2009.

MARX, Karl. O Capital: Crítica da Economia Política. Abril Cultural, São Paulo. Livros I e III. Coleção Os Economistas, 1985.

MILLS, C. Wright. A nova classe média [White Collar]. Rio de Janeiro: Zahar Editores, 1969. 380 p. 1.ed. em inglês, 1951. 
MOORE, Barrington. Privacy: Studies in Social and Cultural History. Sharpe, New York, 1984.

NIPPERT-ENG, Christena, Islands of Privacy, Chicago and London: The University of Chicago Press, 2010

NASCIMENTO, Ródnei, Formas de Subsunção do Trabalho

NISSENBAUM, Helen. "A Contextual Approach to Privacy Online" Daedalus 140 (4), Fall 2011: 32-48. . Privacy in Context: Technology, Policy, and the Integrity of Social Life .Palo Alto, CA: Stanford University Press, 2010.

NYE, David, Consuming Power: A Social History of American Energies ,1999,

PARISER, Eli. O Filtro Invisível: o que a Internet está escondendo sobre você. Rio de Janeiro: Jorge Zahar, 2012.

PENENBERG, Adam L. Viral Loop: From Facebook to Twitter, How Today's Smartest Businesses Grow Themselves. New York: Hyperion, 2009.

POLLET, T. V., ROBERTS, S. G. B., \& DUNBAR, R. I. M. (2011). Use of social network sites and instant messaging does not lead to increased offline social network size, or to emotionally closer relationships with offline network members.CyberPsychology, Behavior, and Social Networking, $14,253-258$.

POSNER, Richard A, Economic Analysis of Law, Aspen Law \& Business, 5th ed., 1998.

PRICKETT, Sarah Nicole. Sign of the Times: Look Out, It's Instagram Envy.The New York Times. 06/11/2013.

PRADO, Eleutério F.S. F. S. Desmedida do Valor: Crítica da Pós- Grande Indústria. Xamã, São Paulo, 2005.

ROSEN, Jeffrey. The Unwanted Gaze: The Destruction of Privacy in America, 2000.

. The Right to be Forgotten. Stanford Law Review Online, 88, $13 / 02 / 2012$ 
SCHAPOCHNIK, N. . Cartões postais, álbuns de família e ícones da intimidade. In: Fernando A. Novais (dir.) ; Nicolau Sevcenko (org.). (Org.). História da Vida Privada no Brasil. 1 ed. São Paulo: Companhia das Letras, 1998, v. 3, p. 423-512.

SENNET, Richard. The Fall of Public Man, New York - London: W. W. Norton \& Company, 1977.

SEVCENKO, N. . A capital irradiante: técnica, ritmos e ritos do Rio. In: Nicolau Sevcenko. (Org.). História da Vida Privada no Brasil: da Belle èpoque à era do rádio. 3 ed. São Paulo: Comapnhia das Letras, 1998, v. 3, p. 513619.

SIMMEL. Georg. O Dinheiro na Cultura Moderna. In: SOUZA, Jessé e ÖELZE, Berthold. Simmel e a modernidade. Brasília: UnB. 1998. p. 23-40.

STREEK, Wolfgang. Citizens as Customers: Considerations on the New Politics of Consumption. New Left Review 76, July-August 2012.

SOLOVE, Daniel. The Future of Reputation: gossip, rumour and privacy on the Internet. New Haven, Conn.: Yale University Press, 2007. . I've got nothing to hide. San Diego Law Review. Vol. 44: 745, 2007.

. Understanding privacy. Cambridge, Mass. Harvard University Press, 2008.

SOMBART, Werner. El burgués: contribución a la historia moral e intelectual del hombre moderno. Tradução de Victor Bernardo. Buenos Aires: Oresme, 1953. 374 p. Título original: Der Bourgeois. 1. ed. em alemão 1913.

SOUZA, Jessé. Os Batalhadores Brasileiros - nova classe média ou nova classe trabalhadora? Belo Horizonte: Editora UFMG, 2010.

A Ralé Brasileira: quem é e como vive, Belo Horizonte: Editora UFMG, 2011 
SOUZA, Jessé e ÖELZE, Berthold. Simmel e a modernidade. Brasília: UnB. 1998. p. 23-40.

STONE, Lawrence, The Public and the Private in Stately Homes of England, 1500-1990, Social Research 58, (1991).

TEIXEIRA, Rodrigo Alves. A Produção Capitalista do Conhecimento e o Papel do Conhecimento na Produção Capitalista: Uma Análise a partir da Teoria Marxista do Valor EconomiA, Brasília(DF), v.10, n.2, p.421-456, mai/ago 2009.

TREPTE, Sabine. e REINECKE, Leonard. The Social Web as a Shelter for Privacy and Authentic Living. In: Privacy Online: Perspectives on Privacy and Self-Disclosure in the Social Web. TREPTE, S. e REINECKE, L (eds.). Springer Verlag Berlin Heidelberg, New York, 2011.

VAN DEN HAAG, Ernest, On Privacy, in Nomos XIII: Privacy 149, 149, J. Ronald Pennock \& J.W. Chapman eds., 1971.

VIANA, Silvia, Rituais de Sofrimento, São Paulo: Boitempo, 2013.

WALLERSTEIN, I. O declínio do poder americano. Rio de Janeiro: Contraponto, 2004.

WARREN e BRANDEIS, The Right to Privacy, 1890.

WEBER, Max. A ética protestante e o "espírito" do capitalismo; tradução José Marcos Mariani de Macedo; revisão técnica de Antônio Flávio Pierucci. São Paulo: Companhia das Letras, 2004.

. Economia e Sociedade. V.1. Tradução de Regis Barbosa e Karen Elsabe Barbosa. Revisão técnica de Gabriel Cohn. Brasília, Editora UnB, 1991.

WOLF, Kurt. The Sociology of Georg Simmel. The Free Press, Glencoe, Illinois, 1950.

WESTIN, Alan, Privacy and Freedom, The Bodley Head Ltd., 1967

YAO, Mike Z. Self-Protection of Online Privacy: a Behavioural Approach. In: In: Privacy Online: Perspectives on Privacy and Self-Disclosure in the Social 
Web. TREPTE, S. e REINECKE, L (eds.). Springer Verlag Berlin Heidelberg, New York, 2011.

ZARETSKY, Eli, Capitalism, the Family, and Personal Life, New York: Harper and Row, 1976

, Why America Needs a Left: an historical argument, Cambrigde: Polity, 2012 